\title{
ENVIRONMENTAL HISTORICAL ANALYSIS OF THE SARMATIAN AND GEPIDS SETTLEMENT OF RÁKÓCZIFALVA
}

\author{
BEÁTA TUGYA ${ }^{1,2}$ - KATALIN NÁFRÁDI ${ }^{2}$ - SÁNDOR GULYÁS ${ }^{2}$ - TÜNDE TÖRŐCSIK ${ }^{2,3}$ \\ BALÁZS PÁL SÜMEGI ${ }^{2}$ - PÉTER POMÁZI² - PÁL SÜMEGI ${ }^{2,3}$ \\ 1: Thúry György Museum, Zrínyi Street 62, H-8800 Nagykanizsa, Hungary \\ tbea82@gmail.com
}

2: University of Szeged, Interdisciplinary Excellence Centre, Institute of Geography and Earth Sciences, Long Environmental Changes Research Team, University of Szeged Department of Geology and Palaeontology, Egyetem Street 2, H-6722 Szeged, Hungary nafradikata@gmail.com; gulyas.sandor@geo.u-szeged.hu; ttorocsik63@gmail.com; sumegi.balazs.pal@gmail.com; pomazi.peter9@gmail.com; sumegi@geo.u-szeged.hu 3: Research Centre for the Humanities, Institute of Archaeology, Tóth Kálmán Street 4, H-1097 Budapest, Hungary ttorocsik63@gmail.com; sumegi@geo.u-szeged.hu

\begin{abstract}
We present the results of the environmental historical and geoarchaeological analysis of Rákóczifalva-Bagiföldek and Rákóczifalva-Rokkant-földek archeological sites in Jász-Nagykun-Szolnok County. ${ }^{1}$ They were discovered in the course of several hectares of archaeological excavations related to the Roman Age and Migration Period, especially the Sarmatian and the Gepids era. A significant number of Gepids sites and finds ${ }^{2}$ were found in both the investigated areas and the wider area of the site, in the middle reach of the Tisza valley. So the geoarchaeological and environmental historical analysis of the Sarmatian and LateSarmatian and Gepids sites in Rákóczifalva can also provide a model for the settling strategy and lifestyle of the Sarmatian and Gepids communities. ${ }^{3}$ The purpose of our work is to present how geoarchaeological and environmental historical factors impacted local settling and lifestyles in the Gepids communities and Sarmatian-Late Sarmatian communities as well ${ }^{4}$ during the Roman Age and the Migration Period. In addition, to demonstrate the relationship of the Sarmatian and Gepids communities and their environment in the Rákóczifalva site compared to other Gepids ${ }^{5}$ and Sarmatian and Late Sarmatian communities in the Great Hungarian Plain. ${ }^{6}$

Based on the number of objects containing animal bones and the amount of bones found in them, we can reconstruct considerable settling in the Celtic, Sarmatian, Gepids, Avar and Arpadian periods. The number of objects from the Linear Pottery culture (Great Hungarian Plain) and the Bodrogkeresztúr culture is high; however, the number of animal bones is low. On the basis of the bones discovered, we can count on a smaller settlement during the Tiszapolgár culture, the Hunyadihalom group, the Halomíros culture, the Gava culture and during the Scythians period.

In this paper, we present the results of the Sarmatian, Late Sarmatian and the Gepid findings since the largest number of animal bones (except the Avar period) turned up from these periods. Our aim was to compare the animal husbandry, meat consumption and hunting habits of the Oriental origin Sarmatians and the Germanic Gepids communities. Bone artefacts and bone anvils have been found in the archaeological material of both ethnic groups.

Keywords: Rákóczifalva, Sarmatian, Late Sarmatian, Gepids, geoarchaeology, pollen analysis, macrobotanical analysis, archaeozoology, bone anvil
\end{abstract}

\section{STUDY SITE}

\section{Natural conditions of the area}

In terms of the borders of the Rákóczifalva-Bagi-föld and Rokkant-föld sites, it can be said that it is protected from the north, south and west, as it is bordered by the Tisza River and the deeper Tisza alluvium (Figs 1, 2, $3,4,5)$. It is open only from the eastern direction because the area is connected eastward to the high river bank of

${ }^{1}$ Excavator Marietta Csányi.

${ }^{2}$ CSEH 1986, CSEH 1990, CSEH 1991, CSEH 1992, CSEH 1993, CSEH 1997, CSEH 1999a, CSEH 1999b, CsEH 2001, CSEH 2002; MASEK 2014

${ }^{3}$ HaVASSY 1998; IstVÁNOVITS 1999; MASEK 2012; MASEK 2014; ISTVÁNOVITS-KuLCSÁR 2018.
${ }^{4}$ KovÁCS et al. 2007, KovÁCs et al. 2008; KovÁCS-VÁCZI 2007; MASEK 2012, MASEK 2014.

${ }^{5}$ B. Тóth 1999, В. Тóth 2006.

${ }^{6}$ Havassy 1998; MASEl 2012, Masel 2014; IsTVÁNOVITSKULCSÁR 2018 


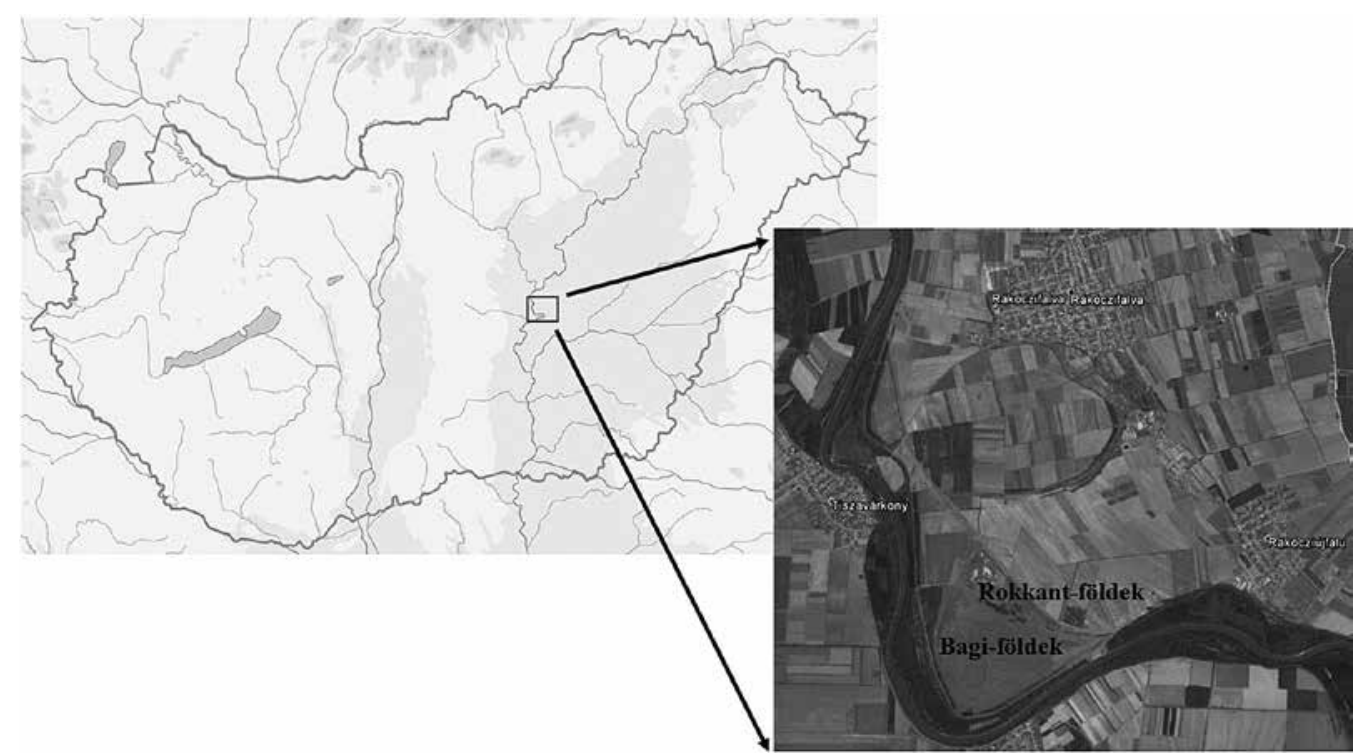

Fig. 1. The location of the study site in Hungary and in GoogleMaps

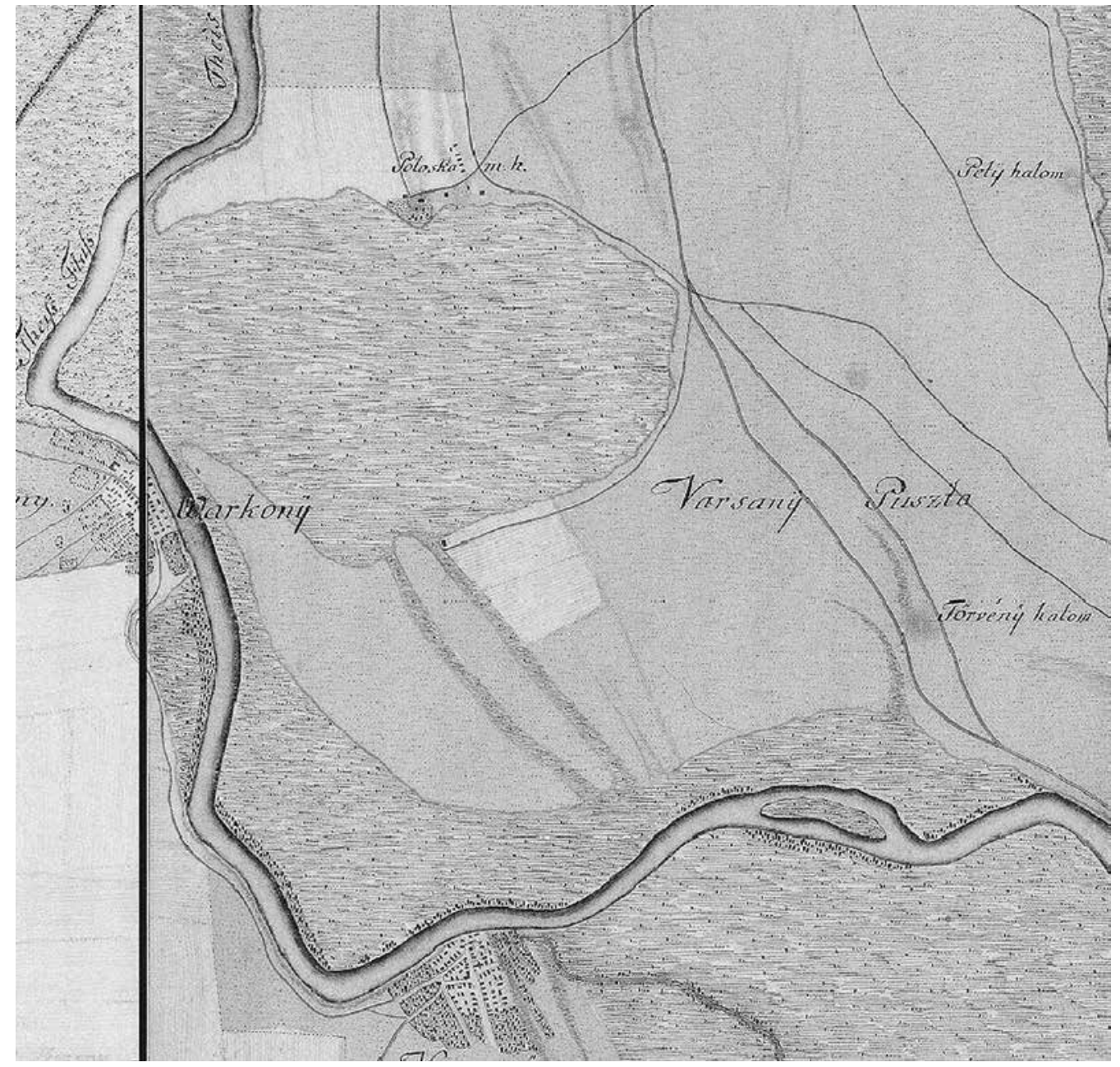

Fig. 2. The morphological conditions and the vegetation of the study site in the First Austrian Military Survey (1782) Acta Archaeologica Academiae Scientiarum Hungaricae 71, 2020 


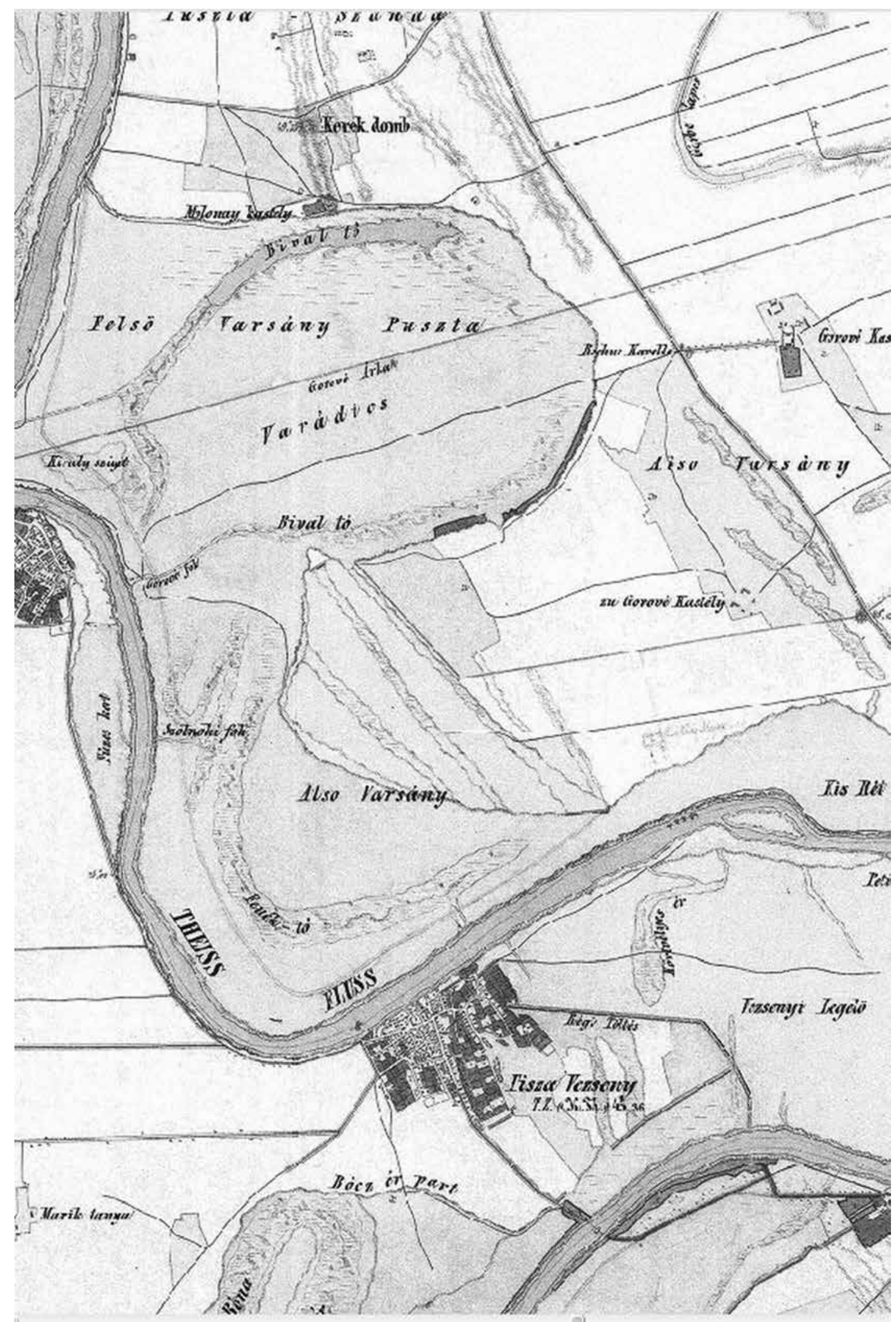

Fig. 3. The morphological conditions and the vegetation of the study site in the Second Austrian Military Survey (1869) 


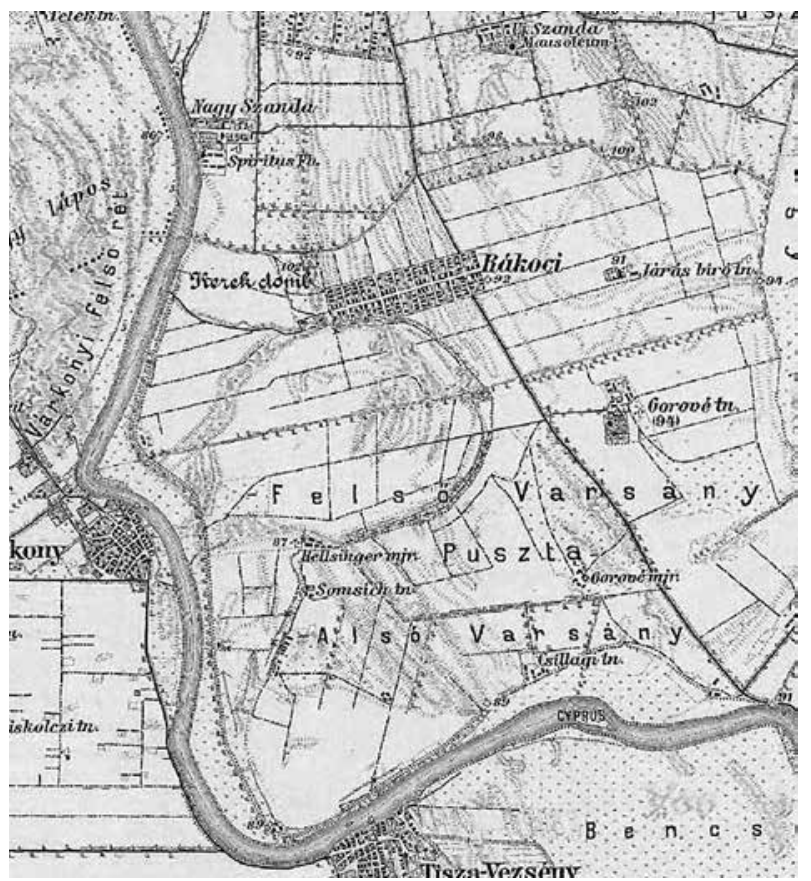

Fig. 4. The morphological conditions and the vegetation of the study site in the Third Austrian Military Survey (1875)

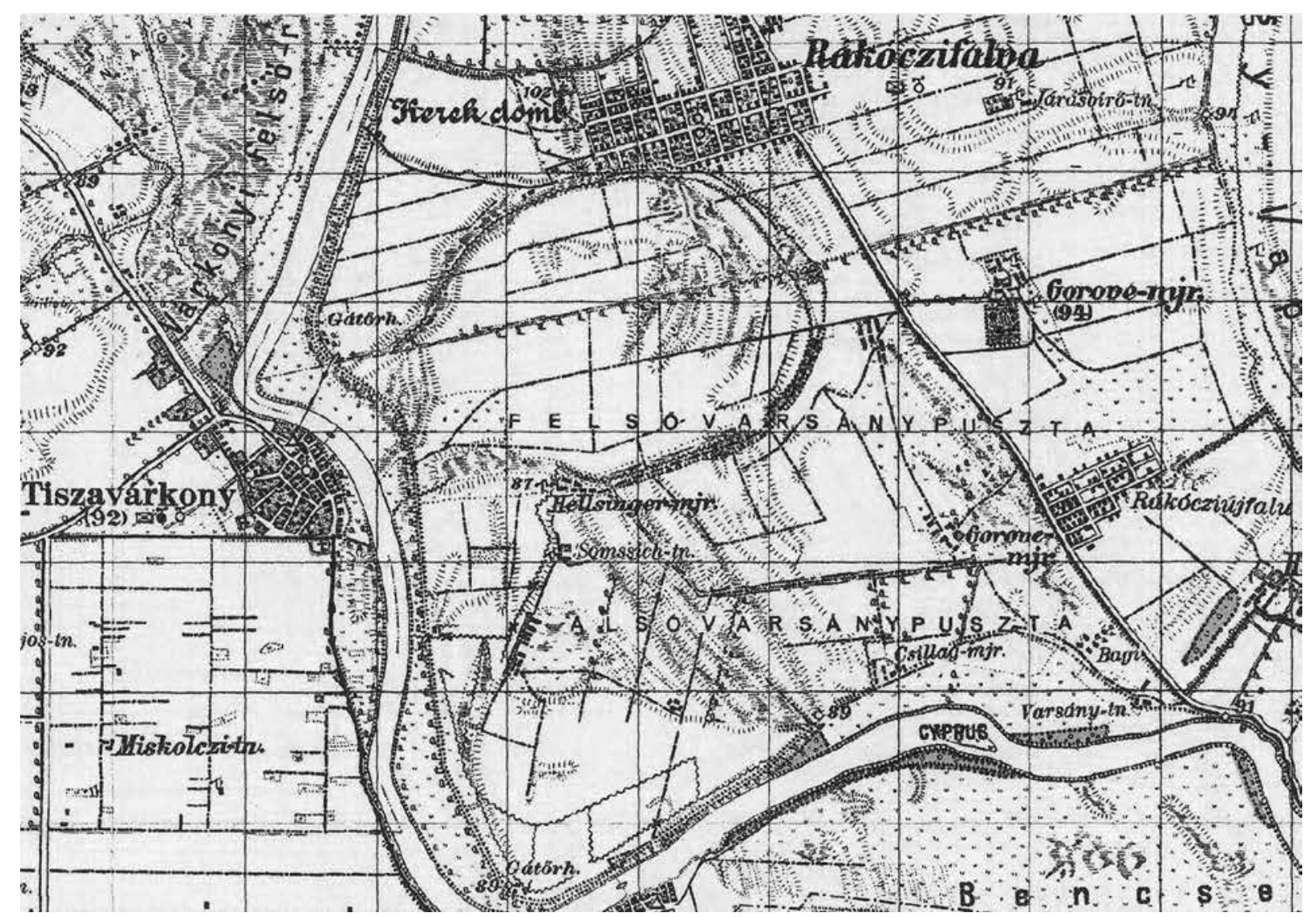

Fig. 5. The morphological conditions and the vegetation of the study site in the Hungarian Military Survey (1943) 
the Tisza River and it extends as a peninsula into the deeper Tisza floodplain. The study site belongs to the Great Hungarian Plain, including the Middle Tisza region, the Nagykunság little region group and the Szolnok-Túri plain, Szolnok-Ártér little regions. It lies in the western part of the Szolnok-Túri plain. The relative relief value of the little region is low, $2 \mathrm{~m} / \mathrm{km}^{2}$. The slightly wavy plain in the study site and the floodplain at the edge of the Tisza River can be classified as orographic relief type. ${ }^{7}$ Examining a 1:10.000 scale map, the deepest point of the area is $79.2 \mathrm{~m}$, and the highest is $90 \mathrm{~m}$. Despite the low relative relief value of the Szolnok-Túri plain, there is a difference of more than $10 \mathrm{~m}$ above sea level difference within a short distance in the study area. This value is extremely high in the Great Hungarian Plain, especially if we consider the general nature of the little region.

The above-mentioned little regions have a moderately warm-dry climate, close to the warm-dry climate. The annual sunshine duration is between 1970 and 2010 hours. The average annual temperature is $10.9^{\circ} \mathrm{C}$ : the mean temperature of the vegetation period is $17.3-17.4{ }^{\circ} \mathrm{C}$. The frost-free period begins on $7^{\text {th }}-8^{\text {th }}$ April, the first autumn frosts are expected around $20^{\text {th }}$ October. So the frost-free period is 196 days long. Annual precipitation is 510-540 $\mathrm{mm}$, the growing period's precipitation amount is $300 \mathrm{~mm}$. The aridity index is $1.3-1.38$. The area is a dry, heavily anhydrous area. Precipitation is $150 \mathrm{~mm}$ less than the local value of the potential evaporation. ${ }^{8}$ Based on the data of the Szolnok meteorological station and the Walter-Lieth diagram ${ }^{9}$ (Fig. 5), the area belongs to the driest areas of the Great Hungarian Plain. On the basis of the average annual rainfall of $500 \mathrm{~mm}$ and the distribution of rainfall (Fig. 6), there is a significant risk of drought in the second half of summer and in autumn. This occurs especially when continental and/or sub-Mediterranean climate effects develop, resulting in maximum monthly temperature conditions (Fig. 6) in the examined area. In this case, evaporation exceeds rainfall at the end of summer and early autumn, and periodic steppe climatic conditions develop.

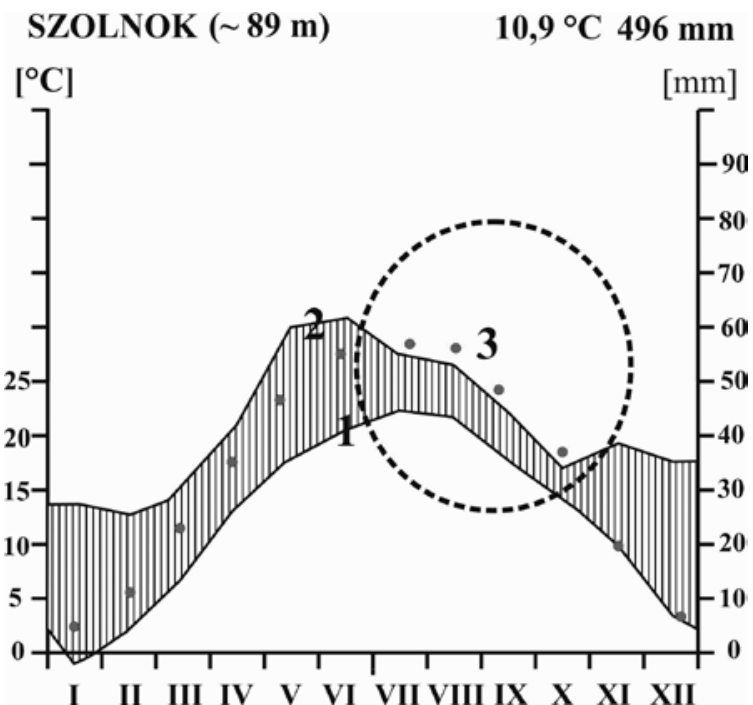

Fig. 6. Walter-Lieth diagram based on the meteorological station in Szolnok. $1=$ monthly average temperature values; $2=$ monthly average precipitation values;

$3=$ dashed circle, drought period, red circle $=$ monthly maximum temperature values

Based on the bioclimatic analysis of the Carpathian Basin, ${ }^{10}$ the study site belongs to the central part of the Pannonian forest steppe zone (Fig. 7). At the same time, the little regions belong to the Tiszántúl flora region. Potential forest associations are willow-poplar-alder gallery forest, oak-ash-elm gallery forest, alkaline oak forest and loess-mantled terrain (Aceri tatarico-Quercetum) in the floodplain. ${ }^{11}$ Vegetation development and its change will be analyzed later, as we have a pollen core from the area that was revealed by the Department of Geology and Paleontology of the University of Szeged. Based on the recent plant associations, the examined area is a cultivated steppe:

\footnotetext{
${ }^{7}$ Marosi-Somogyi 1990.

${ }^{8}$ Marosi-SOMOGYi 1990.

${ }^{9}$ WaLter-Lieth 1960.
}

${ }^{10}$ SZELEPCSÉNYI et al. 2014, SZELEPCSÉNYi et al. 2018. 
pastures with weeds, poplar and acacia plantations, in deeper areas swamp vegetation mixed with weeds or with saline plants occur.

On the basis of the cores of the Department of Geology and Paleontology, University of Szeged two types of recent soils can be distinguished in the area. One of them is the chernozem soil that can be found on natural elevations, and the other is the alkaline meadow soils (Fig. 8) which have a significant water effect.

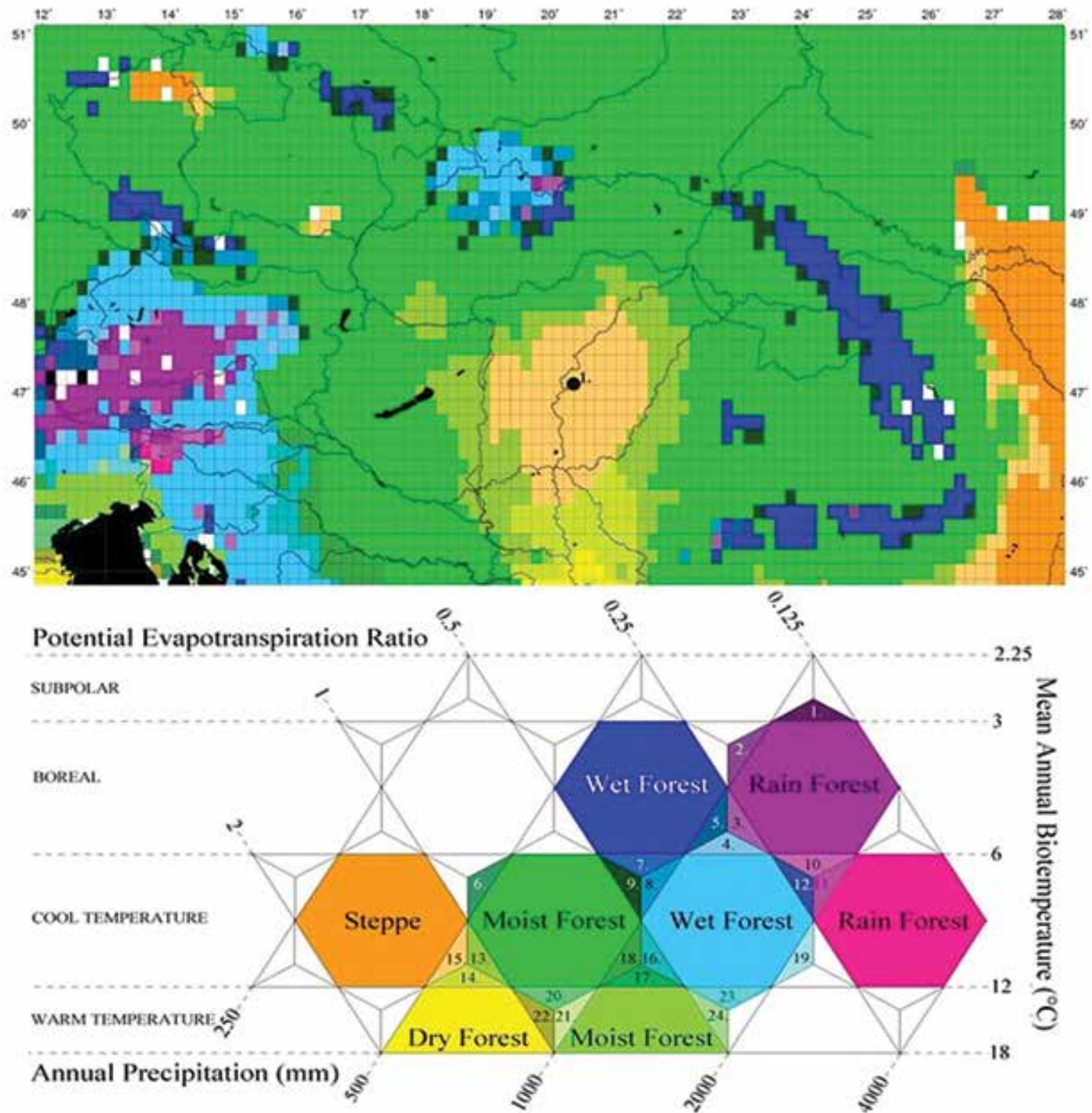

Fig. 7. Position of the analyzed region on spatial distribution of the Carpathian Region's core and transitional life zones for the beginning of $20^{\text {th }}$ century based on the Holdridge modified life zone system (SZELEPCSÉNYI et al. 2014, SZELEPCSÉNYI et al. 2015, SZELEPCSÉNYI et al. 2018) 
The results of the Kreybig soil mapping (1933) and pedological mapping (Fig. 8) were used to characterize the soils of the examined area. ${ }^{12}$ In this historical map, alluvial meadow, chernozem, alkaline and sandy soil types were identified in the study site, but in a different spatial extension compared to our results.

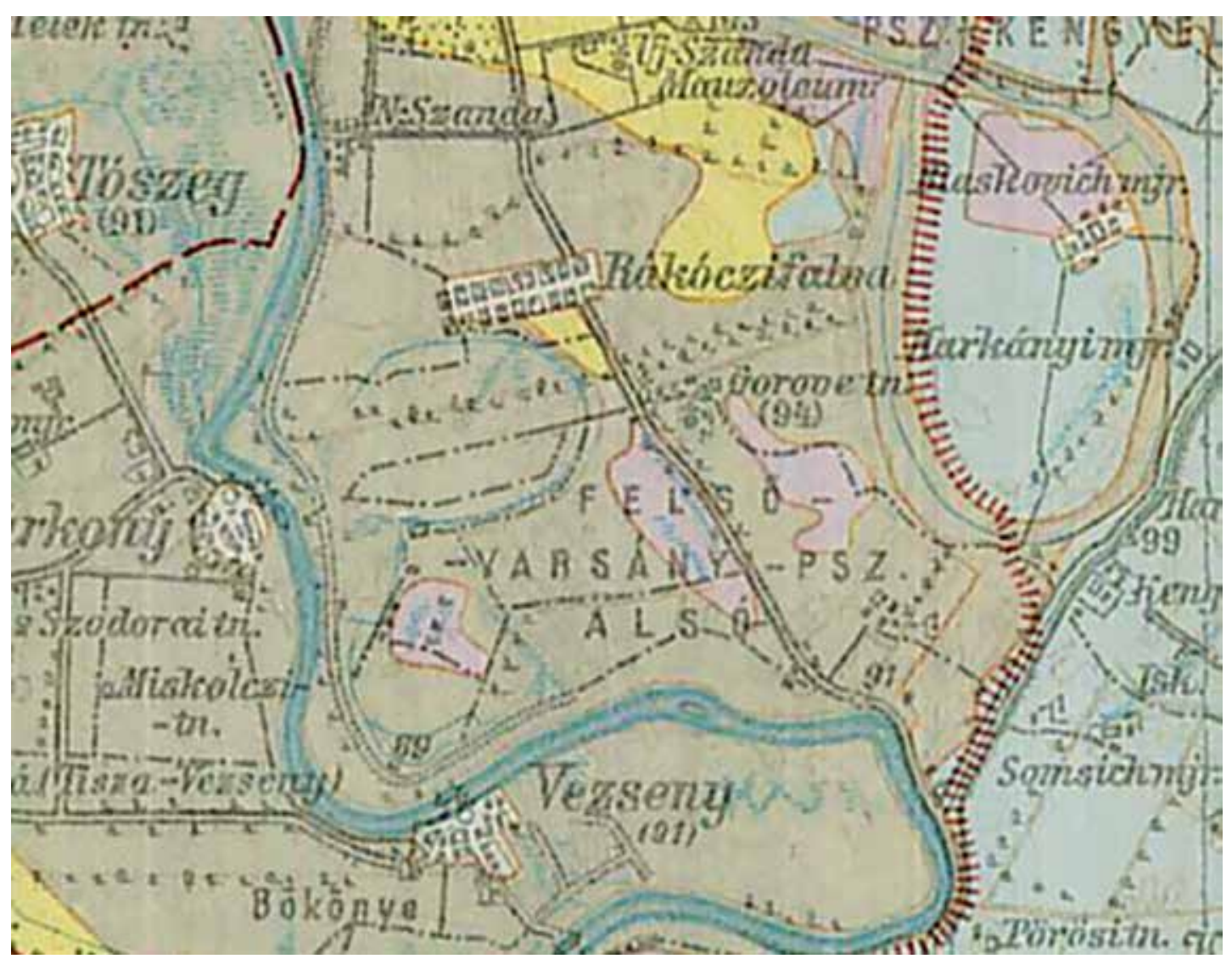

Fig. 8. Pedological map of Lajos Kreybig (1937) about the study site (indicated as Felső and Alsó Varsány-puszta in the map). brown color $=$ chernozem soil, blue color $=$ hydromorphic soil, purple color $=$ alkaline soil, yellow color $=$ sand soil

\section{GEOLOGY AND EVOLUTION OF THE AREA}

Since only Quaternary formations could be detected on the surface of the examined area (Figs 9, 10), the geological development history of the area is presented by discussing Quaternary events. The bedrock of these Quaternary formations is Tertiary sediments lying more hundred meters deep from the surface. Among these, the most significant layer is the Törteli Formation ${ }^{13}$ that developed at the end of the Tertiary, in the last phase of the Pannonian filling up. The Zagyva Formation developed on the Törteli Formation. ${ }^{14}$ Thin-layered clay, aleurite and sandstone layers accumulated indicating a delta background, presenting marshy and floodplain environment. Its upper level evolved in an alluvial plain, in a fluviolacustrine environment. After the fluviolacustrine state, the water network of the Great Hungarian Plain changed and was significantly different from the current water network: the Tisza river flowed eastern than nowadays. The Danube River met the Tisza at the height of Csongrád. ${ }^{15}$ According to the latest data ${ }^{16}$ the Tisza valley was formed about 20,000 years ago. The Tisza River, which until then followed the valley of the Körös and Berettyó creeks, bypassed the Nyírség from the north and took its current direction. ${ }^{17}$

\footnotetext{
${ }^{12}$ KREYBig 1937.

${ }^{13}$ JUHÁSZ 1992

${ }^{14}$ JUHÁSZ-MAGYAR 1992; JUHÁSZ 1992
} MOLNÁR 1965

${ }^{15}$ SÜMEghY 1944, SÜMEGHY 1953; MihÁLtZ 1953;

\footnotetext{
${ }^{16}$ TIMÁR et al. 2005.

${ }^{17}$ SÜMEGHY 1944.
}

Acta Archaeologica Academiae Scientiarum Hungaricae 71, 2020 
Thus, in the Tisza region, the Tisza River became significant regarding morphology and sedimentology from the Upper Wurmian (MIS2) ${ }^{18}$ Due to tectonic movements sediments (of Tisza origin) of different age in different altitudes can be found in the area. ${ }^{19}$ So it is not surprising that upper Pleistocene-Holocene sediments cover the surface in Rákóczifalva-Bagi-föld and Rokkant-föld sites. Older Pleistocene layers and the Pliocene bedrock sediments (clay, sand) are known only from drilling. ${ }^{20}$

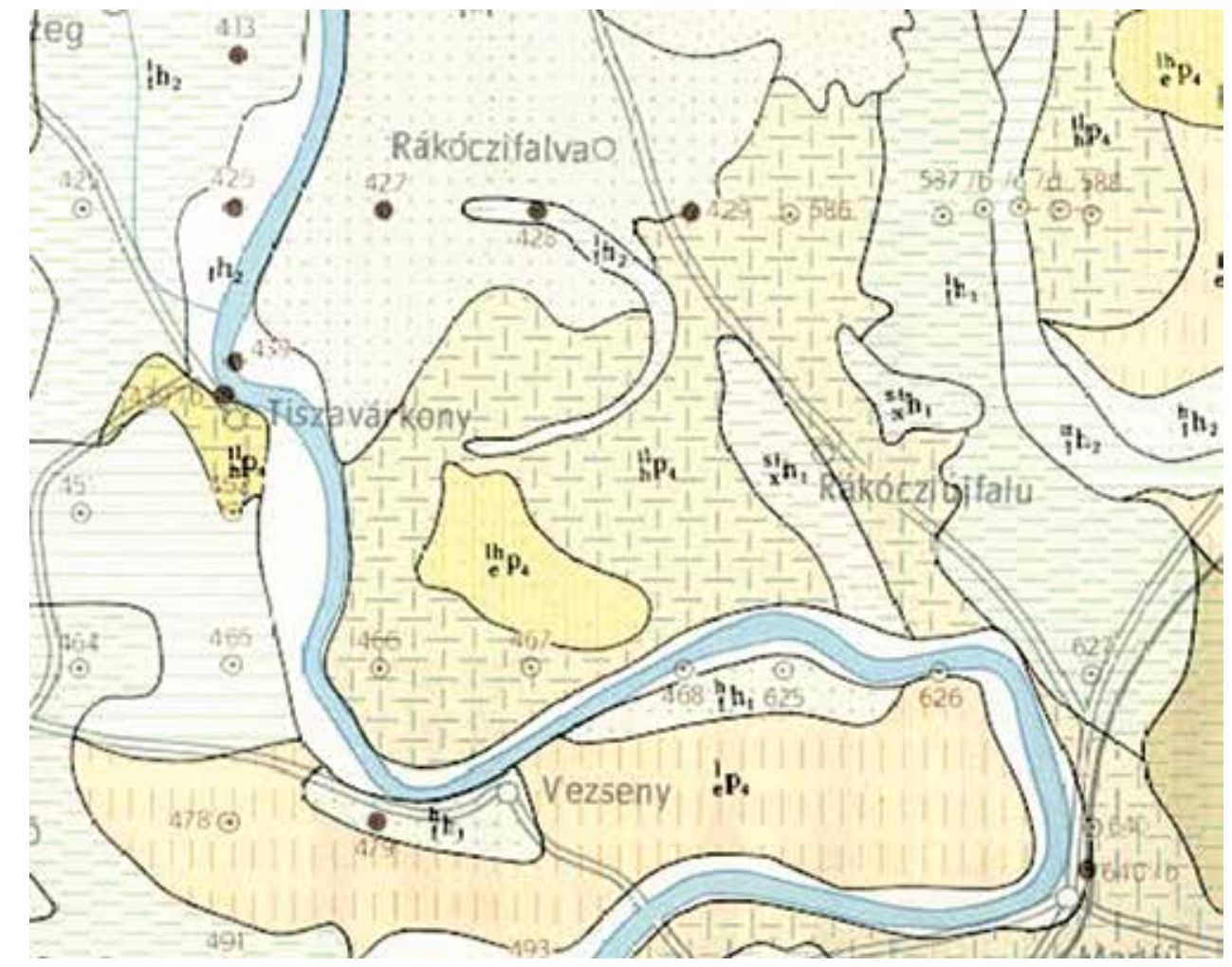

Fig. 9. Geological structure of the study site

(based on the 1:100000 scale geological map of the Hungarian National Geological Institute, 1969)

Tószeg

Perje-Csat. Tisza

Rákóczífalva

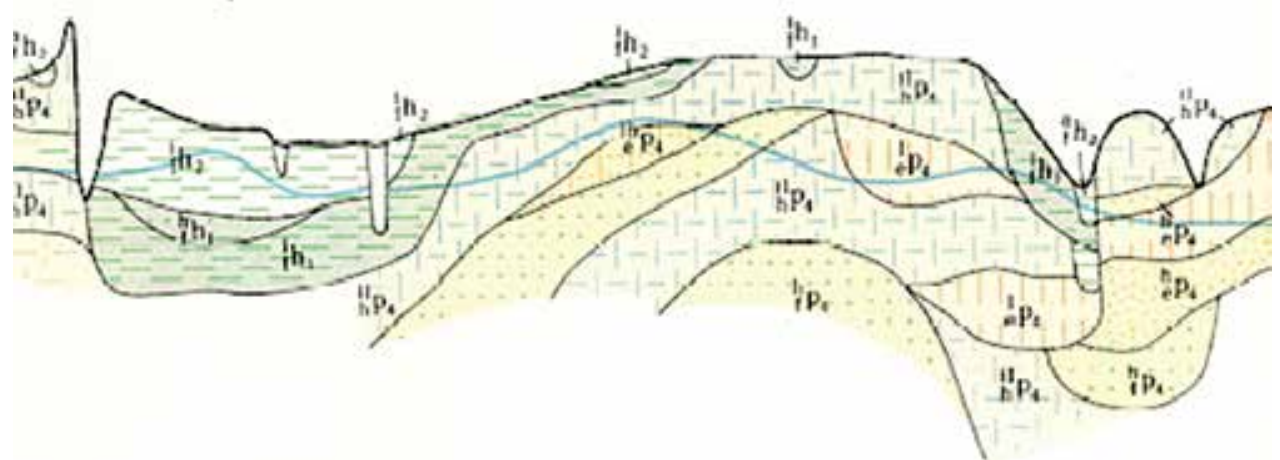

Fig. 10. Geological cross section of the study site (based on the 1:100.000 scale geological map of the Hungarian National Geological Institute, 1969)

\footnotetext{
${ }^{18}$ SÜMEGI et al. 2018.

${ }^{19}$ RÓNAi 1972, RÓNAI 1985,;Timár et al. 2005.
}

${ }^{20}$ RÓNAI 1972, RÓNAI 1985. 
The most widespread upper Pleistocene sediment on the surface is loess; the type of loess that is connected to rivers and floodplains, i.e. a Pleistocene floodplain sediment, ${ }^{21}$ formerly known as loess like Pleistocene alluvial sediment or better-known infusion loess (alluvial loess). Infusion loess differs from typical loess in its porosity, carbonate and clay content and biofacies. ${ }^{22}$

In the Middle Tisza region, there was also sand movement, which can be observed today north of the examined area in Szolnok-Szandaszőlös. The sandy area of Tiszaföldvár at the southern part of the Szolnok-Túri plain is the continuation of the sandy area of the Danube-Tisza Interfluve. ${ }^{23}$

The results of the geological mapping were compared with the results of the geological map of József Sümeghy and András Rónai. The 1:200.000 scale geological map of the Tiszántúl (1941) by Sümeghy and the complex maps of the Great Hungarian Plain (Fig. 9), the 1:100.000 scale Szolnok map sheet made by András Rónai. In the Sümeghy map, 'old-Holocene' and 'new-Holocene' alluvial soil surrounded the island-like 'upper Pleistocene lowland loess' formation. The expansion and position of the loess formation in the Great Hungarian Plain is very similar to that of the alkaline soil 'island' surrounded by alluvial soil in the Kreybig map.

The results of the mapping of the Great Hungarian Plain led by A. Rónai are similar, although it showed a more inaccurate result in the examined area. ${ }^{24}$ Their cross-section of several drillings is slightly south of our study area; two drillings were conducted in the study site (Fig. 10). Based on their map, infusion loess covered (floodplain sediment) surface was explored in the area, and the residual surface was surrounded by deeper Pleistocene and Holocene channels and beds filled with fine-grained sediments and still developing alluvial plains (Figs 9, 10).

The geological surveys before our study pointed to Pleistocene muddy loess and infusion loess (floodplain) sediments in the Rákóczifalva-Bagi- and Rokkant-földek sites. In the middle of this sediment Pleistocene loessy sand was found, according to these maps. In the northern part of the area, semi-circular shaped Holocene aleurite appeared (Fig. 9). East of this area the residual surface is covered by Pleistocene muddy loess and infusion loess. The southern area is not uniform in a geological point of view. From east to west the map indicates loess (aleurite rich sediment), muddy loess, infusion loess (floodplain sediment), riverine sand, loessy sand and close to the Tisza River muddy, infusion loess occurs again.

\section{METHODS}

\section{Analysis of historical maps of the site}

Examination of the maps before and after river regulations (1847) is as follows. Although the study site can be recognized in the maps of Ptolemaiosz (FEHÉR 2004), Tabula Peutingeriana from the end of Antiquity, ${ }^{25}$ Angelino Dulcert from the medieval period $(1339)^{26}$ and in the map of Lázár deák from $1528,{ }^{27}$ but the first maps that can be evaluated from an environmental historical point of view are the maps from the $18^{\text {th }}$ century (AD). The First (1782), the Second (1869) and the Third (1875) Austrian Military Survey and the Hungarian Military Survey ${ }^{28}$ from World War II were used in our study. We also used the Middle Tisza region map ${ }^{29}$ of Lietzner-Sándor (1970) by János Lietzner Keresztelö, the county engineer of the County Heves-Külső Szolnok (Fig. 11). By analyzing historical maps, we tried to reveal the development of the area and the effect of human impact.

\footnotetext{
${ }^{21}$ SÜMEGI 2005; SÜMEGI et al. 2015.

${ }^{22}$ HorusitZKy 1898, HoRUSITZKY 1899, HorUSITZKY 1903, HORUSITZKY 1905, HoRUSITZKY 1909, HORUSITZKY 1911; PÉCSI 1993; SÜMEGI et al. 2015,

${ }^{23}$ Halaváts 1895; Miháltz 1953; MolnáR 1965; RónAi 1972, RÓNAI 1985.
}

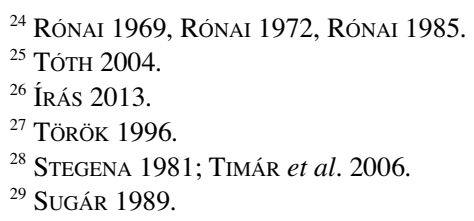

Acta Archaeologica Academiae Scientiarum Hungaricae 71, 2020 


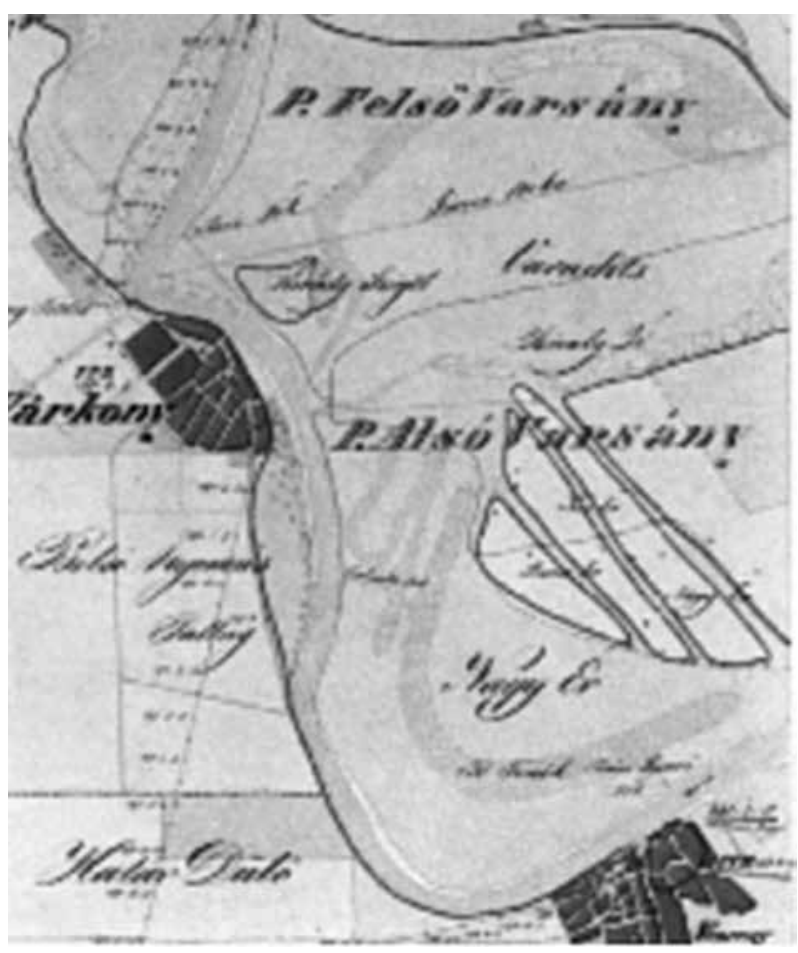

Fig. 11. The map of the study site by Sándor Lietzner (1790)

\section{Exogenous geological analysis}

An EOV map with a scale of 1:10,000 is available from the area. Using this map, we have calibrated the measurement points using ArcView 3.2 software. After that, we created the digital relief model of the area (1:10000 EOV map) using ArcGIS software. The digital relief model was used for the geomorphological analysis of the study site. In addition, we used the aerial photographs prepared by the Archaeological Institute of the Eötvös Loránd University to map the local surface of the area. The purpose of the exogenous geological-morphological analysis was to reconstruct the environment of the site as accurately as possible.

\section{Geoarchaeological analysis}

During geoarchaeological analysis 300 shallow (3-5 $\mathrm{m}$ deep) cores were taken at $5 \mathrm{~cm}$ intervals by a spiral drilling machine (SÜMEGI, 2001, SÜMEGI 2002, SÜMEGI 2013) in Rákóczifalva-Bivaly-tó, Bagi-földek and Rokkant-földek site. Boreholes were created along geological sections parallel to each other in such a way that all exogenous geological-geological-pedological units were explored. We used the international nomenclature of Troels-Smith ${ }^{30}$ during sediment description.

Undisturbed samples were taken by a Russian corer $^{31}$ by overlapping technique ${ }^{32}$ in a filled up point bar channel at the boundary of the Rokkant-földek and Bagi-földek sites. Samples were cut lengthwise and stored in the usual manner at $4^{\circ} \mathrm{C}^{33}$ Size distributions, organic material, carbonate content (LOI) and pollen analytical analysis was carried out. In describing the colours of the sediment, the Munsell soil colour charts were used. ${ }^{34}$ The sedimentological analysis was carried out using an Easy Laser Particle Sizer 2.0. laser particle sizer (42 grain fractions) after proper sample preparation. ${ }^{35}$

30 Troels-SMITH 1955.

${ }^{31}$ BELOKOPYTOV-BERESNEVICH 1955

${ }^{32}$ SÜMEGI 2001, SÜMEGI 2002, SÜMEGI 2013.
33 SÜMEgi 2001, SÜMEGI 2002, SüMEGI 2013.

${ }^{34}$ COLOUR 1991.

${ }^{35}$ SÜMEGI et al. 2015. 
During magnetic susceptibility analysis, the magnetizable element content of the sediment is measured. For this purpose, air-dried and powdered samples are prepared to measure the loss of mass. Bartington MS2 Magnetic Susceptibility Meter was used at $2.7 \mathrm{MHz}^{36}$ that is suitable for laboratory and field analysis as well. Three measurements were done for each sample and values were averaged.

Dean's method (1974) was used for the determination of carbonate and organic material content. Sedimentological and LOI analysis was carried out and interpreted at $4 \mathrm{~cm}$ intervals. We presented the sedimentological data and succession, and the cross-section of geoarchaeological data using the Psimpoll software by Keith D. Bennett (1992).

\section{Pollen analyses}

Pollen analytical analysis was carried out on the undisturbed samples of the core deepened in the point bar channel. The retrieved cores were also subsampled at 1-2-4-cm intervals for pollen analysis. A volumetric sampler was used to obtain $2 \mathrm{~cm}^{3}$ samples, which were then processed for pollen. ${ }^{37}$ Lycopodium spore tablets of known volume were added to each sample to determine pollen concentrations. A known quantity of exotic pollen was added to each sample in order to determine the concentration of identified pollen grains. ${ }^{38} \mathrm{~A}$ minimum count of 500 grains per sample (excluding exotics) was made in order to ensure a statistically significant sample size. ${ }^{39}$ The pollen types were identified and modified according to Moore et al. 1991, Beug 2004 and PunT et al. 2007, KozÁKOVÁPOKORNY 2007, supplemented by examination of photographs in REILLE 1992, REILLE 1995, ReILLE 1998 and of reference material held in the Hungarian Geological Institute, Budapest. Percentages of terrestrial pollen taxa, excluding Cyperaceae, were calculated using the sum of all those taxa. Percentages of Cyperaceae, aquatics and pteridophyte spores were calculated relative to the main sum plus the relevant sum for each taxon or taxon group. Calculations, numerical analyses and graphing of pollen diagrams were performed using the software package Psimpoll 4.26. ${ }^{40}$ Local pollen assemblage zones (LPAZs) were defined using optimal splitting of information content, ${ }^{41}$ zonation being performed using the 20 terrestrial pollen taxa that reached at least $5 \%$ in at least one sample. The paleovegetation was reconstructed using the works of SUGITA 1994, SOEPBOER et al. 2007, JACOBSON-BRADSHAW 1981, Prentice 1985 and MAgYari et al. 2010.

Pollen extraction was carried out with the help of Tibor Cserny geologist, in the former laboratory of the Hungarian Geological Institute.

\section{Macrobotanical analysis}

The archaeobotanical material (anthracological) was obtained from the samples collected by 4 to $10 \mathrm{~cm}$, flotated from uniformly $2.7 \mathrm{~kg}$ of samples. The quantity of the samples is in accordance with the German standards. ${ }^{42}$ In obtaining and processing the samples, we followed the guidelines of Ferenc Gyulai (GyULAI 2001) regarding the sampling and flotating process. In flotating the samples, the dual flotating method and $0.5 \mathrm{~mm}$ and $0.25 \mathrm{~mm}$ sieves were used. ${ }^{43}$

Charcoal material was analyzed using a Zeiss Jenapol optical microscope at 10, 20, 50 and $100 \times$ magnification. ${ }^{44}$ Wood identification was carried out using the reference book of GREGUSS 1945, GREGUSS 1972 and SCHWEINGRUBER 1990 and the web-based identification work of SсHOCH et al. 2004.

\footnotetext{
${ }^{36}$ SÜMEGI et al. 2015.

${ }^{37}$ BERGLUND-RALSKA-JASIEWICZOWA 1986

${ }^{38}$ STOCKMARR 1971.

${ }^{39}$ IVERSEN-FÆGRI 1964; FÆGRI-IVERSEN 1989; PUNT 19761995; MOORE et al. 1991.
}

\author{
${ }^{40}$ BenNeTT 2005. \\ ${ }^{41}$ BIRKS-GORDON 1985. \\ 42 JACOMET-KREUZ 1992. \\ ${ }^{43}$ NÁFRÁDI-SÜMEGI 2013 \\ ${ }^{44}$ NÁFRÁDI-SÜMEGI 2015. \\ Acta Archaeologica Academiae Scientiarum Hungaricae 71, 2020
}




\section{Archaeozoological analysis}

Table 1. The number of objects which contain animal bones and the number bones in every period

\begin{tabular}{|l|l|c|}
\hline Age/Culture & Objects within bones & Number of bones \\
\hline AVK & 16 & 245 \\
\hline Tiszapolgár culture & 1 & 26 \\
\hline Bodrogkeresztúr culture & 13 & 219 \\
\hline Hunyadihalom group & 2 & 31 \\
\hline Copper Age & 2 & 64 \\
\hline Tumulus culture & 4 & 79 \\
\hline Gáva culture & 3 & 31 \\
\hline Bronze Age & 1 & 1 \\
\hline Scythians & 1 & 18 \\
\hline Celts & 9 & 628 \\
\hline Prehistorical & 5 & 25 \\
\hline Sarmatians & 88 & 886 \\
\hline Late Sarmatians & 11 & 244 \\
\hline Migration (Dark) Age & 1 & 11 \\
\hline Gepids & 11 & 1012 \\
\hline Sarmatians + Gepids & 1 & 47 \\
\hline Avars & 66 & 1059 \\
\hline Árpád Age & 18 & 533 \\
\hline New Age & 2 & 2 \\
\hline Undifferent cultures & 13 & 592 \\
\hline
\end{tabular}

A large volume of bones, more than 6000 pieces of animal bones occurred from ten archaeological cultures in the study sites, from the middle Neolithic (AVK) to the Arpadian Age. So the area was often inhabited for thousands of years. In addition, there were also objects of Copper Age (Tiszapolgár culture, Bodrogkeresztúr culture), Bronze Age (Tumulus culture, Gáva culture), Celtic, Sarmatian and Avars with more or less vertebrate remains. Most of the finds are well preserved, only some of the prehistoric bones were in poor condition, often heavily laced, which made the determination difficult. Altogether 979 pieces were found in Gepid archaeological objects that were in excellent condition. Identification of bones was carried out using the reference books of SISSON 2014 and SCHMID 1972, and the work of VON DEN DRIESCH 1976 for bone size measurement.

\section{RESULTS}

\section{Historical maps}

The analysis of historical maps (Figs 2-5) clearly shows the transformation of landscape utilization in the study sites before and after river regulation processes (1847). Although in the First Austrian Military Survey (Fig. 2) the nomenclature is still very poor and the morphological survey was not entirely accurate, in addition, the mapping of the Tisza coast was rough, it was obvious that in the coastal area of Tisza River (in the Bagi-földek site, according to archaeologists) there were only gallery forests suitable for floodplain farming and marshy, boggy areas. It was also clearly visible in the First Austrian Military Survey (1782; Fig. 2) that in the Rokkant-földek (as it is called by archaeologists) in the area called Varsány Puszta (in the later survey Alsó Varsány (Fig. 3) and Alsó Varsány puszta (Fig. 4)) there are two periodic creeks between the Bivaly Lake and the Tisza valley. The first Austrian military map does not indicate the name of the Bivaly Lake; only a temporary, swampy area is marked. An abandoned, over-developed, unregulated curve of Tisza River can be reconstructed from its drawing (Fig. 2).

In other parts of the area scattered gardens, arable lands, grazing fields representing extensive animal husbandry are indicated in the first Austrian military map (Fig. 2). In addition, several mounds that help location identification are shown in the study area (Fig. 2). 
The Second Austrian Military Survey (1869) is critical in an exogenous geological and morphological point of view (Fig. 3). Bivaly Lake has been shown in this map, which clearly shows that it is an earlier over-developed curve of the Tisza River, which was connected to the regulated Tisza River through water outlet (canal) only periodically, during floods (Fig. 3). From this area of the Bivaly Lake (Felső (Upper) Varsány puszta), through Alsó (Low) Varsány puszta, four deeper, canal-like formations led to the actively developing valley of the Tisza (called Bagi-földek in our work). According to the map of Lake Fenék, there was a lake in the area of Bagi-földek. This lake was connected to the active Tisza River through the water outlet of Szolnok. Based on the map, the Bagiföldek was a suitable area for fishing, gathering, waterfront farming (gathering of gallery forest crops, sedge, reed, construction and wood utilization for energy) before river regulations. On the basis of exogenous geological characters, the Bagi-földek was a point bar series of the unregulated Tisza River (Fig. 3).

At the same time, in the second Austrian military map, Rokkant-földek (Alsó (Lower) Varsány) is an older (probably Pleistocene) residual surface, a point bar series rising a few meters above the alluvium of Tisza River. It did not affect the development of the Tisza alluvium at the end of the Pleistocene, and during the Holocene, instead, it seems to be a terrace level (Fig. 3). The second Austrian military map (1869) clearly shows the traces of groundwater regulation, the groundwater drainage ditches and the artificial barrier system along the active riverbed of the Tisza River (Fig. 3). At the same time, settlements and the associated gardens and arable lands are extensive, while grazing fields and pasture lands can be observed in smaller regions further from the settlements and are more clearly defined than in the First Austrian Military Survey (Fig. 3).

Based on the map prepared by the Second Austrian Military Survey (1869), it is clear that north from the Bagi-földek, on the alluvium of the Tisza River called Varsány puszta, there is a large abandoned Tisza River channel, the Bivaly Lake, which has been transformed into an oxbow. At the same time, south from the Bagi-földek the point bar series in the riverbed of the Tisza River (that is younger than the Bivaly Lake) is called Fenék Lake (Fig. 3). In the Bagi-földek (Alsó (Lower) Varsány in the second military survey) that is emerging from the Tisza alluvium there are more channel like hollows (Fig. 3), older point bar channels a few hundred meters apart from each other. Bagi-földek is located in a peninsula-like form in the Tisza alluvium. Its eastern part has already been utilized as a ploughland, but the surface above the point bar channels has been utilized as pasture land (Fig. 3).

The Third Austrian Military Survey (1875) shows the impact of river regulation, the drainage channels, the formation of a barrier system along the Tisza River, the development of the floodplain area between the dams and the development of settlements. In addition, the geographical names and the exogenous geological units that were already noticed and described in the Second Austrian Military Survey (Fig. 4) can be observed.

In the Hungarian Military Survey (1943) dam-system protected settlements, roads, the extension of arable lands and garden cultures and the transformed landscape and agricultural system as a result of river regulation and groundwater drainage can be observed (Fig. 5). The nomenclature of the Hungarian Military Survey was used by the geologists of the Hungarian Royal Geological Institute and the Hungarian Geological Institute during the geological and pedological mapping of the Great Hungarian Plain (Figs 8, 9, 10).

In the Lietzner-Sándor map of 1790 (Fig. 11), the recording of the Middle Tisza region was completed. ${ }^{45}$ In this map, the emerged location of the point bar structure of the Rokkant-földek and the deeper location of the Bagi-földek associated with the Tisza alluvium can be clearly seen (Fig. 11). In addition to the analysis of historical maps, we prepared the digital elevation model (Figs 12,13) of the area to understand the exogenous geological situation and morphological conditions during the Sarmatian and Gepids era. The 1:10000 scale digital elevation model clearly demonstrates the existence of a point bar series in a deeper position that is related to the unregulated Tisza riverbed and developed in the curve of the Tisza River over a few centuries. To the northeastern direction in an elevated position (residual surface or terrace level), a series of an older point bar can be found (Figs 12, 13).

Based on the digital elevation model, the Bagi-földek site is located in the deeper and younger alluvium of the Tisza River characterized by good water supply. The Rokkant-földek site in an older residual surface which is rising above the alluvium. In this older point bar series, only periodic flood water flew through the point bar channels from the direction of the Bivaly Lake towards the Tisza alluvium (Figs 12, 13). So Sarmatian and Gepids communities settled in the point bar series of the high and low floodplain. These surfaces provided different farming possibilities for the Sarmatian and Gepids communities of the Migration Period: the utilization of the gallery forest,

${ }^{45}$ SUGÁR 1989. 
gatherings in the area of the forests and floodplain, fishing and hunting, extensive animal husbandry on the higher, drier areas and plant cultivation around the settlements and houses.

As our goal was to reconstruct the environmental history of the Sarmatian and Gepids settlement as complex as possible, we conducted geoarchaeological drillings (Fig. 14) along a double geological section that explored the deeper (Bagi-földek) and the higher (Rokkant-földek) point bar series as well (Fig. 14). Based on these drillings,

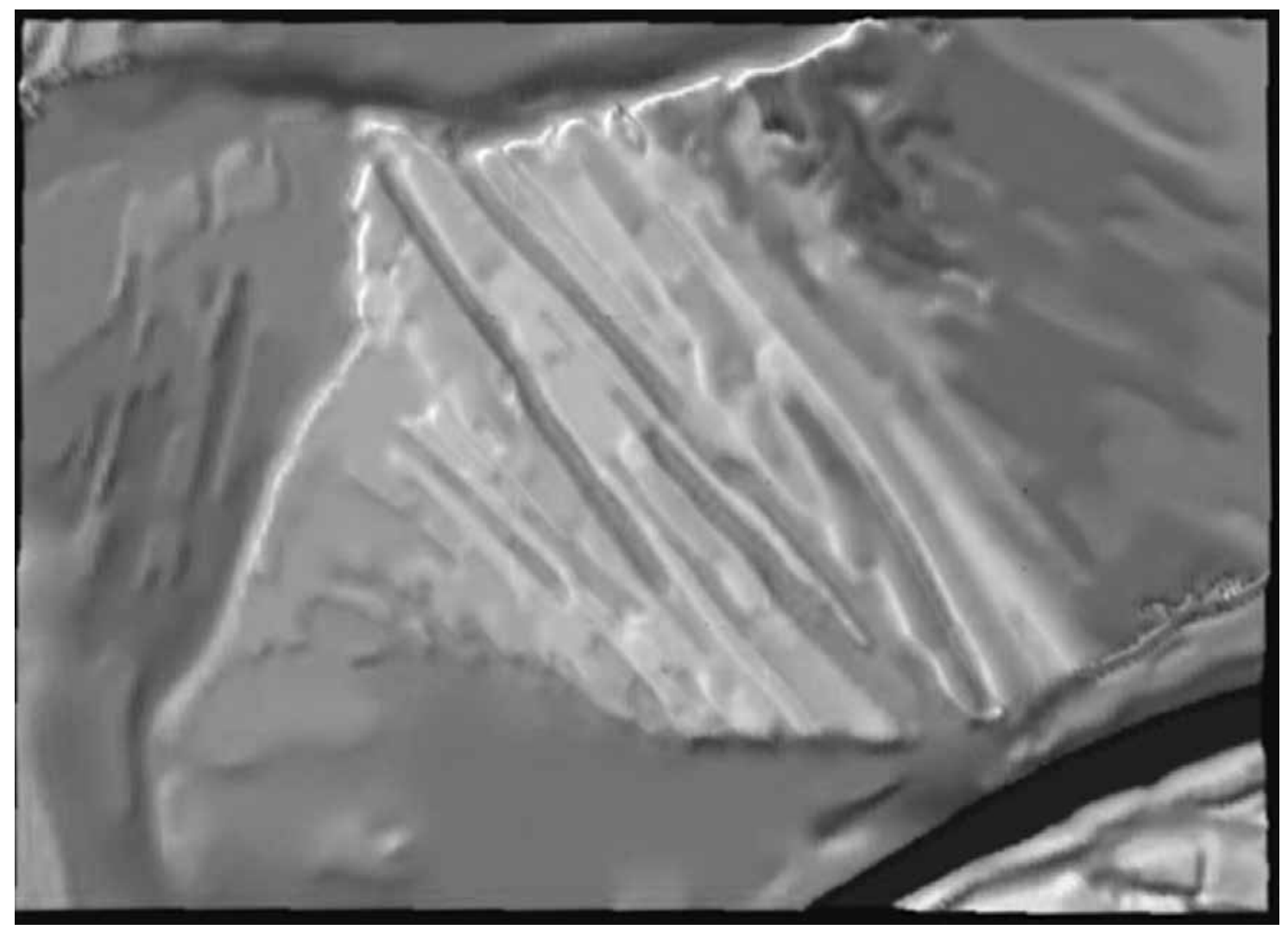

Fig. 12. Digital elevation model of the study site

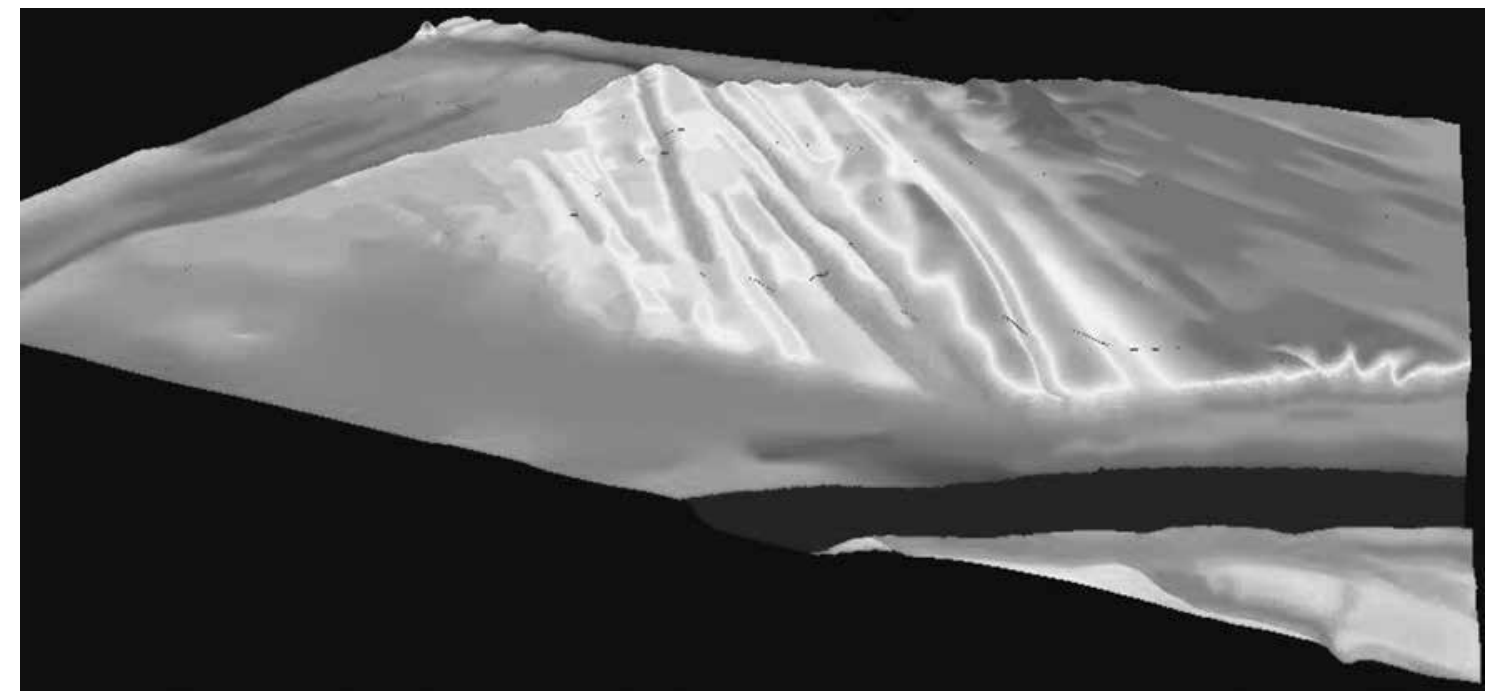

Fig. 13. 3D drawning of the study site on the basis of the digital elevation model 


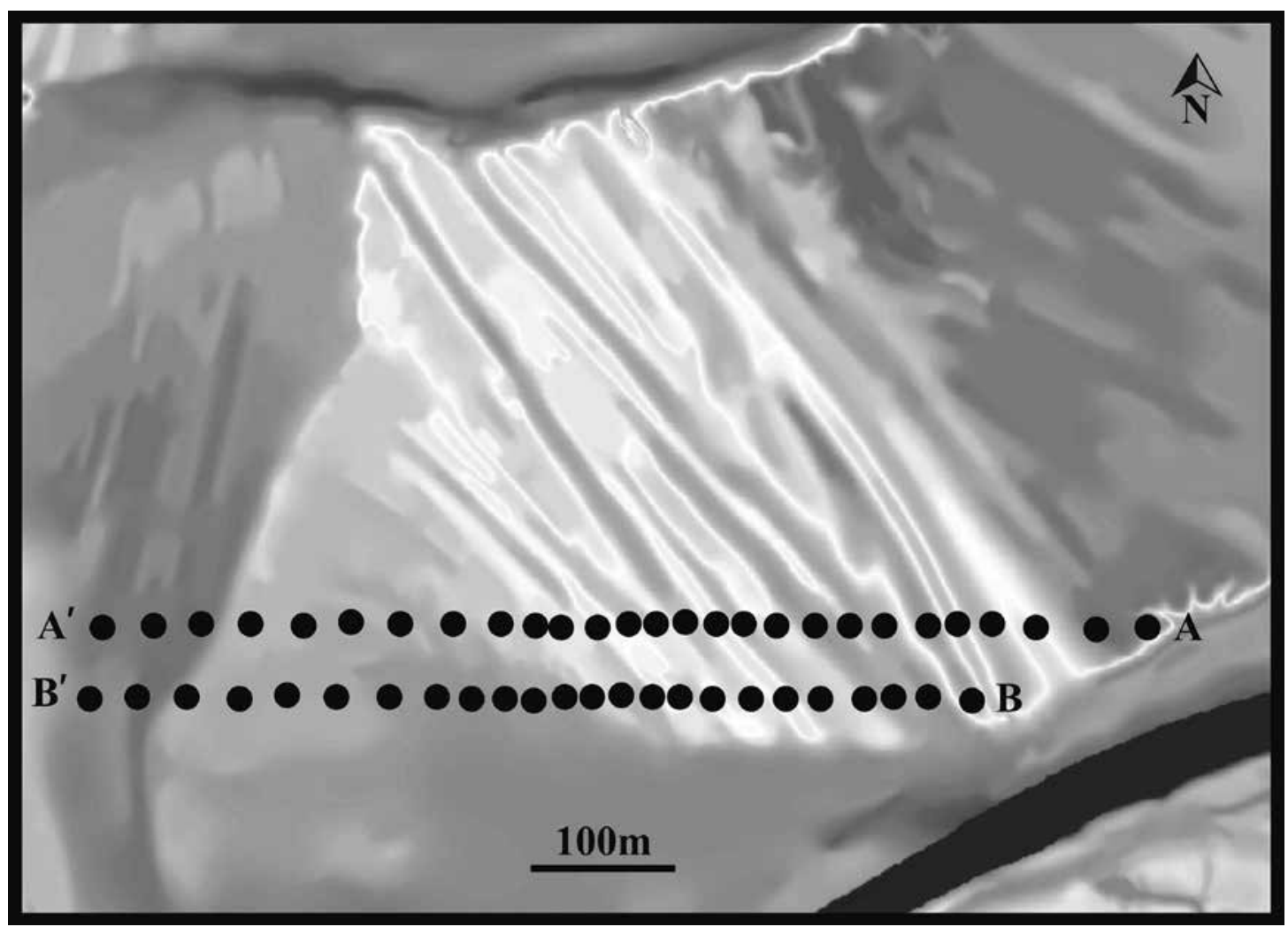

Fig. 14. The location of parallel geological sections and geoarchaeological drilling points in the digital elevation model of the site

the geological and pedological conditions of the exogenous geological and geomorphological units could be mapped and the environmental, geological and pedological characters of the Sarmatian and Gepids communities could be specified (Fig. 14).

After the formation of the geological profile (Figs 14, 15) it was confirmed that the point bar series in the Rokkant-földek developed at the end of the Pleistocene. This is proved by the loess-like sediment layers of the point bar channels excavated by drillings, the relatively high position, and the carbonate and coarse aleurite-rich sedimentary environment. The deeper geological position of the Bagi-földek is of Tisza alluvium origin, its clay and organic material rich geological layers support its Holocene formation and development (Fig. 15).

The Bagi-földek got continuous water supply through the water outlet system of the Tisza, until to the Tisza River regulation processes and dam building; so in the Migration Period, at the time of the settling of the Sarmatian and Gepids communities, there could not be permanent settlements in this area only in higher elevations (Rokkantföldek), in the semi-peninsula-like Pleistocene point bar series (Figs 12-15). Since the Pleistocene higher, flood-free surface is semi-circular, peninsula-like (Figs 11-14), the settling of archaeological cultures, including the Sarmatian and Gepids houses and settlements in the Rokkant-földek, follows a camber form (Fig. 16). So, the Sarmatian and Gepids communities lived in the boundary of two different local ecoregions, in the edge of a flood-free area that has good water supply, in a protected, elevated area surrounded by living waters (Figs 12, 13, 16). This settling strategy, the closeness of living water, the high position, the flood-free island-peninsula-like Pleistocene residual surface for settling, animal husbandry and plant cultivation in the Great Hungarian Plain was established since the Early Neolithic. The first data on this type of land utilization was published by Tibor Mendöl, a Hungarian social geography researcher in 1928 and 1929, before the recognition and phrasing of the culture. ${ }^{46}$ Mendöl made a colorued contour map of Szarvas and its surroundings, including the so-called Érpart, a Neolitic settlement. He recognized the Pleistocene loess covered higher, flood-free surfaces and ascribed them to the area of Neolithic set-

${ }^{46}$ Mendöl 1928, Mendöl 1929. 


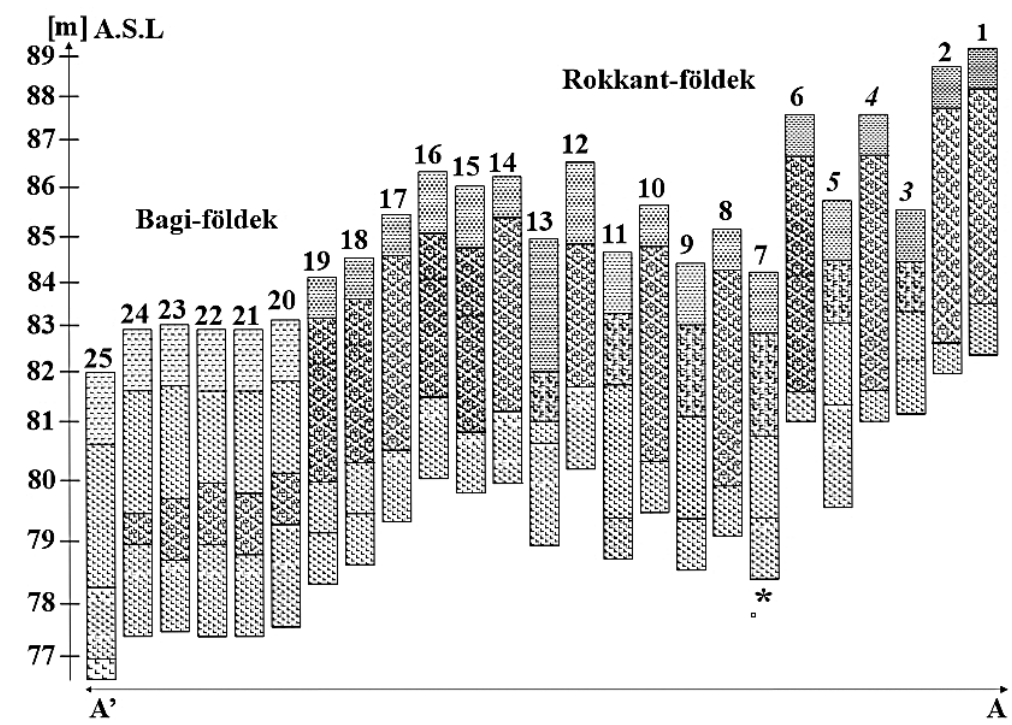

Fig. 15. Geological section of the Bagi-földek and Rokkant-földek in Rákóczifalva and the layers of the cores (TroELs-SMITH 1955 symbols). A.S.L. $=$ Above Sea Level; $*$ = undisturbed core sequence for pollen analyses; A - A' $^{\prime}=$ geological section

tling, farming and livestock breeding. He also described the periodically flooded floodplains that were covered by reed, gallery forest and tussock sedge and were utilized for hunting and gathering. This theory has been repeatedly reinforced during environmental and geoarchaeological research in the Tisza River and its adjacent valleys. ${ }^{47}$ So the Sarmatian and Gepids communities utilized one of the most important features of the Great Hungarian Plain, i.e. its local (few hundred $\mathrm{m}^{2}$ to a few $\mathrm{km}^{2}$ ), mosaic-like nature. Thus, the settlements were in a transition zone regarding regarding the geomorphological (Fig. 16). As a result, the elevated chernozem soil covered surfaces (cereal cultivation, gardens) and areas of alluvial soils (floodplain forest management, grazing, gathering, meadows fields), saline soils (sheep grazing), the canal lakes, living waters (fishing) and water outlet channels (wells) were located within $5 \mathrm{~km}$, approximately one hour walk from the Sarmatian and Gepids settlements. So, all food-producing areas were reached by the members of the Sarmatian and Gepids community within an hour walk (within a $5 \mathrm{~km}$ radius). In addition, the semi-circular, peninsula-like settling in the Tisza floodplain and alluvium provided significant protection in the Great Hungarian Plain.

\section{Sedimentological analysis}

At the $7^{\text {th }}$ drilling point of the first geological core section, a $3 \mathrm{~m}$ deep undisturbed core was taken with overlapping technique in the Pleistocene point bar channel. During the drilling, the following layers were described by the method of Troels-Smith (1955). Magnetic susceptibility, particle size analysis, LOI and water-soluble element content analysis were investigated. The Late Holocene near the surface part that is significant regarding the Sarmatian and Gepid era and the Roman Age and Migration Period were sampled at $2 \mathrm{~cm}$ intervals for sedimentological and water-soluble elements content, while the Pleistocene and Early Holocene bedrock level at $4 \mathrm{~cm}$ intervals.

In the bedrock between 300 and $240 \mathrm{~cm}$ yellowish-grey (Munsell colour 10 YR 7/4) slightly cross-laminated sandy aleurite, aleuritic sand developed. The layer gradually transformed towards the surface and a parallel laminated structure appeared, and fine sandy coarse aleurite, coarse aleuritic fine sand dominated sediment layer developed. In this level carbonate filled root structures appeared, called biogalleries. Grain size indicates coarse grains, although grain size distribution is variable; the organic material content is low, while the carbonate content is the highest. Magnetic susceptibility (MS signal) and the sediment and LOI content indicate minimal changes in

\footnotetext{
${ }^{47}$ NANDRIS 1970, NANDRIS 1972; Kosse 1979; SHERRATT 1982, SherratT 1983; CREMASCHI 1992; SÜMEgi 2003, SÜMEgi 2004; SÜMEGI-MoLNÁR 2007; SÜMEGI 2012; SÜMEGI et al. 2012.
} 


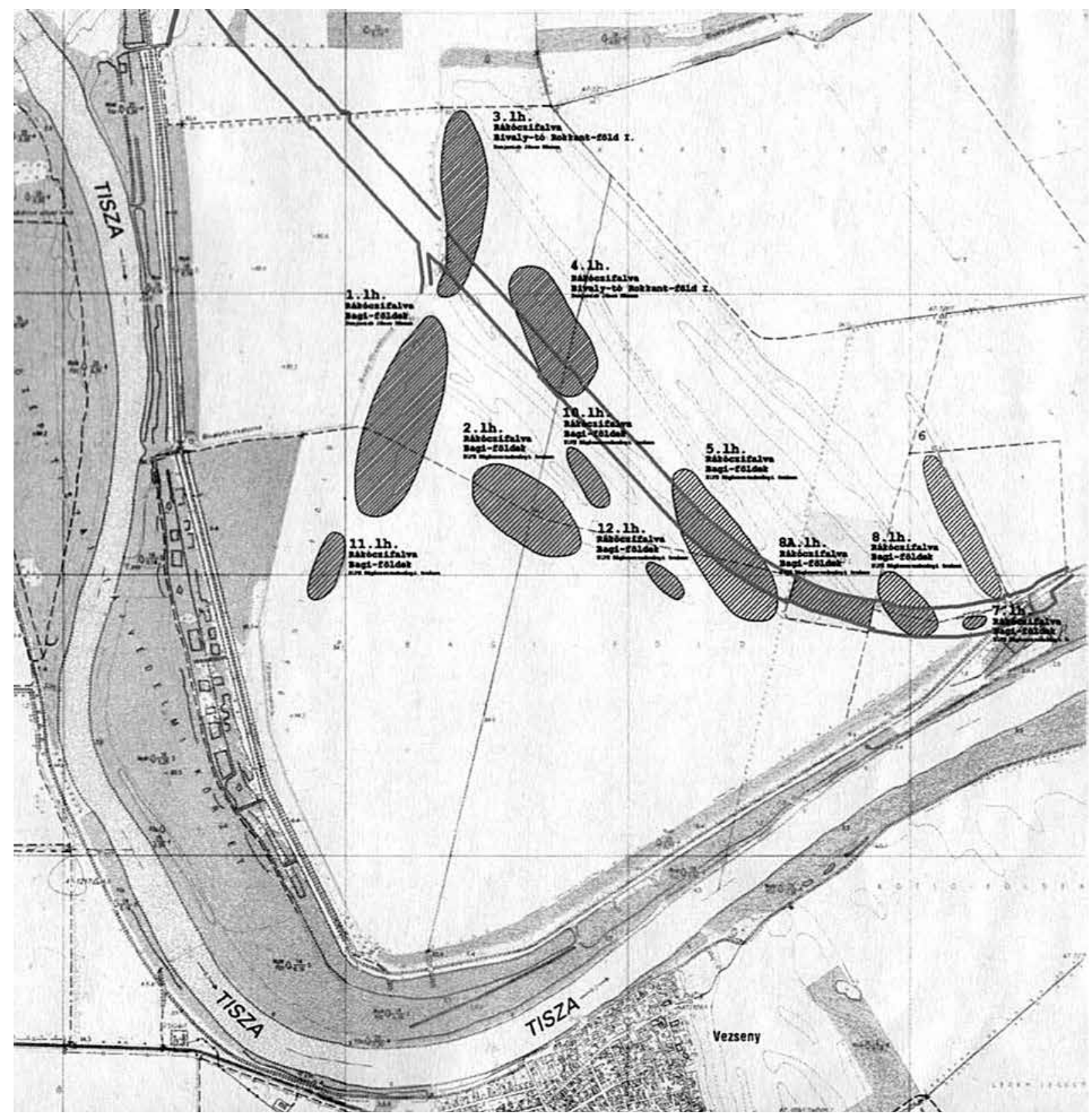

Fig. 16. The location of the archaeological sites in Rákóczifalva and the Gepid settlement

the development of the layer, but the changing values of water-soluble elements suggest significant water cover and cyclic drying periods.

The development of laminations occurred at a maximum thickness of $1 \mathrm{~cm}$, and it is likely that in this interval we could have reconstructed stronger cycles of sedimentation and development due to the sedimentological changes of the sample. The development of the layer can be linked to the active evolving stage of the Pleistocene point bar and the late phase of the channel filling up. Due to its emerged position, its high carbonate content and water-soluble $\mathrm{Ca}$ and $\mathrm{Mg}$ content, the point bar did not belong to the sedimentation area of Tisza River. ${ }^{48}$ Probably the development of the point bar was the result of the development of the catchment area of the Danube River.

${ }^{48}$ MolNÁR 1965. 
Grain size distribution changed between 240 and $160 \mathrm{~cm}$. Sand content decreased in this level of the profile and yellowish-brown (10 YR 5/6) fine aleuritic coarse aleurite, coarse aleuritic fine aleurite dominated layer developed. In the near-surface part of this level, a significant sand fraction rise occurred that can be linked to an extraordinary flood period. The carbonate content increased considerably as well as organic material content, however this latter less in the colour of the sediment appeared. The slightly reddish shade was associated with an a increase of water-soluble iron.

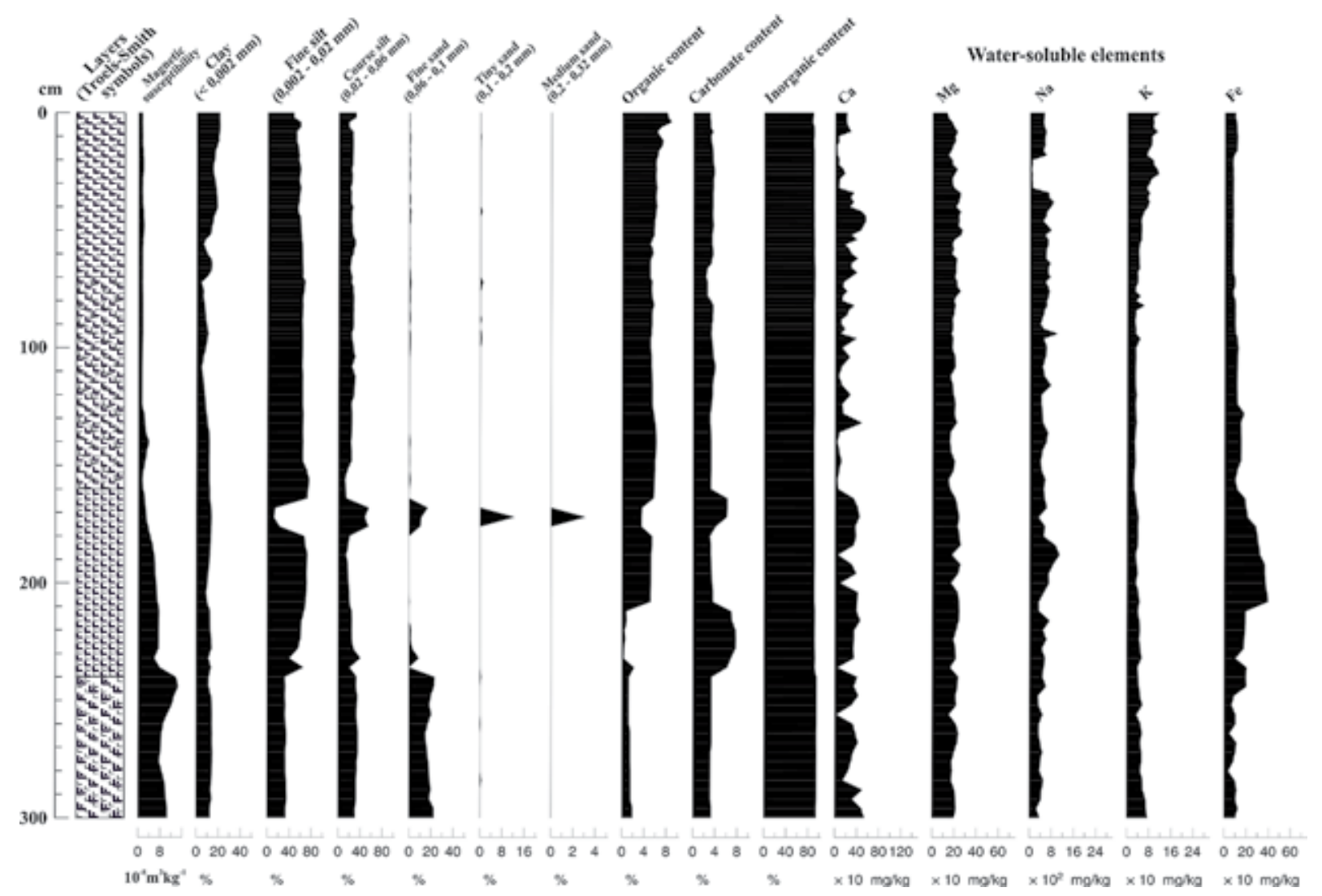

Fig. 17. Sedimentological and geochemical results from the undisturbed core sequence of an infilled point-bar channel in Rokkant-földek at Rákóczifalva

Based on the development of the sediment and sediment parameters, the point bar could gradually emerge due to the appearance and incision of the Tisza River. As a result, the active development of the point bar was completed and transformed into a drainage system at the end of the Pleistocene. In this level of the profile, a flood cycle could be detected based on significant sand intercalation according to grain composition analysis. This level developed at the end of Pleistocene; however, this whole layer was clearly evolved in a stagnant water environment. The development, appearance and facies of the sediment are specific to point bar loess, floodplain sediments formed at the end of the Pleistocene. ${ }^{49}$

Between 160 and $70 \mathrm{~cm}(10$ YR 4/2) clayey fine aleurite accumulated. The organic material content increased, the carbonate content was steady, indicating major soil formation and weathering at the early stage of Holocene. At the same time among water-soluble elements, Fe content decreased. This may indicate a deeper groundwater location and post-movement of elements after water regulation processes of the $20^{\text {th }}$ century, and the cyclic change of groundwater level may be indicated by the cyclic change of other water-soluble elements. The development of this sediment layer can be linked to soil formation and more favourable weather conditions at the beginning of the Holocene; in addition, to the leaching of sediments with significant clay and organic material

${ }^{49}$ SüMEGI et al. 2015. 
content. However, element composition could have changed as a result of groundwater level decrease associated with modern water regulation as well.

Between $70 \mathrm{~cm}$ and the surface a slightly polyhedron structured, blackish brown (10 YR 3/1), clay-rich fine aleurite with significant organic material content developed and soil formation has started. This layer may be marshy-eutrophic lake sediment initially, but its element composition has changed as a result of soil formation and modern water regulation. The latter is primarily shown by the reduction of water-soluble Fe content and the less significant MS signal. Although the layer where soil formation has started represent hydromorphic soil formation characters (polyhedron structure), the significant water-soluble $\mathrm{Na}$ and $\mathrm{K}$ content indicate salinisation and an upward moving groundwater system with significant water-soluble elements in the capillary zone. As a result, besides hydromorphic soil formation, saline soil development started in the area as well. These processes were observed already in the $20^{\text {th }}$ century during the geological survey and agrogeological (pedological) mapping of the area ${ }^{50}$

According to our data, during the Migration Period, during the existence of the Sarmatian and Gepids kingdom, ${ }^{51}$ an organic material rich lake-swamp system appeared in the examined area. This layer has transformed due to soil formation that was the result of the modern river and groundwater regulation.

\section{Pollen analysis}

According to the pollen analysis carried out on samples of the point bar channel, 10 pollen units (pollen horizons) were separated in the profile.

The first pollen horizon developed between 300 and $240 \mathrm{~cm}$. Statistically evaluable pollen material did not occur; only a few samples contained scattered Gramineae and Pinus pollen indicating drying processes.

The second pollen horizon evolved between 240 and $210 \mathrm{~cm}$. Statistically evaluable terrestrial pollen materials were found that reached the minimum of 500 pieces of pollen grains ${ }^{52}$ In this level, the non-arboreal pollen (NAP) material exceeded 60\% while arboreal pollen (AP) grain ratio was below $40 \%$ with Pinus subgenus Pinus taxa, which can spread to significant distances (Fig. 18). On the basis of the pollen composition, a Pleistocene open parkland with scattered pine trees and willow-alder trees existed. In addition, grassy cold steppe vegetation developed in the environment of the area at this time.

The third pollen zone developed between 210 and $170 \mathrm{~cm}$. The pollen composition did not change, but the proportion of AP exceeded 50\% (Fig. 18). This indicates a cold forest steppe (AlLEN et al. 2000, PRENTICE et al. 1996) at the end of the Pleistocene (Fig. 18). The rise of woody vegetation ratio was caused by an increase in the proportion of Pinus genus, which can spread to significant distances. Thermo- and mesphillous elements could not be detected among deciduous trees; only narrow-leaved trees appeared such as willow and alder with higher tolerance-level. Compared to the previous zone humidity increased.

The fourth pollen horizon developed between 170 and $130 \mathrm{~cm}$. AP ratio was between 50 and $60 \%$; although the amount of deciduous trees and shrubs, especially birch (Betula) and hazel (Corylus) are higher. Mixed forest steppe developed. Among woody vegetation coniferous trees and birch (Betula) dominated while herbaceous taxa indicate grasses-wormwood-pigweed dominated. Cold steppe, forest steppe existed with patches of trees.

The fifth pollen zone developed between 130 and $110 \mathrm{~cm}$. The ratio of coniferous trees remained significant, while the proportion of deciduous trees and shrubs increased, especially the ratio of birch (Betula; Fig. 18). Thermo-mesophillous (oak, ash, elm, lime) pollen appeared and AP ratio rose to 60-70\%, which corresponds to the forest steppe phase (AlLEN et al. 2000, PRENTICE et al. 1996) and to the northern part of the Euroasian forest steppe zone $;{ }^{53}$ in addition to the forest steppe zone mixed with taiga in the drier basins of the Altai region. ${ }^{54}$ This pollen horizon corresponds to the transition phase of the Pleistocene and Holocene.

The sixth pollen zone developed between 110 and $80 \mathrm{~cm}$ (Fig. 18). The ratio of coniferous elements decreased, as well as that of herbaceous taxa. AP ratio decreased to $50-60 \%$ that corresponds to a temperate forest steppe ${ }^{55}$ at the beginning of the Holocene, similarly to other residual surfaces in the Tisza valley ${ }^{56}$ In other words,

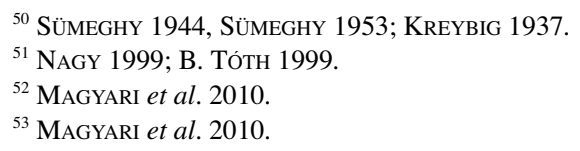

${ }^{54}$ SÜMEGI 1996; SÜMEGI et al. 1999, SÜMEGI et al. 2013a; MAGYAR et al. 2014; TÖRŐCSIK-SÜMEGI 2016.

${ }^{55}$ Allen et al. 2000; PRENTICE et al. 1996.

${ }^{56}$ SÜMEGI et al 2005 .

Acta Archaeologica Academiae Scientiarum Hungaricae 71, 2020 
the climatic, pedological, relief and bedrock conditions in the area led to the development of a mild continental climate, temperate forest steppe development after the cold forest steppe phase at the end of the Pleistocene. These data clearly disprove the theories that forest steppes in the Great Hungarian Plain are the result of human transformation of a forest environment. ${ }^{57}$ On the basis of these publications, human impact has been continuously increased in the Great Hungarian Plain from the emergence of Neolithic farming. This led to the creation of cut-off areas in the forest environment that had expanded due to technical development and growing population. So a mosaic-like forest steppe vegetation has stabilized in the Great Hungarian Plain probably already in prehistoric times, before the emergence of land cultivation. Our data from the Rákóczifalva sites together with our previous data ${ }^{58}$ clearly demonstrates the natural development of the temperate forest steppe in the Great Hungarian Plain (Pannonian forest steppe biogeographic unit). This pollen horizon is the level of hardwood gallery forest (oak-ash-elm), forest steppe (oak-lime-hazel) and grassy steppe mosaics, without human impact.

The seventh pollen zone developed between 80 and $60 \mathrm{~cm}$ (Fig. 18) when hornbeam (Carpinus) and beech (Fagus) appeared and became dominant. Parallel to this, pollen indicating crop production and animal husbandry, cereals and pollen of weeds appeared in the section. It is likely that this pollen level is in accordance with the Neolithic and the beginning of the Copper Age, i.e. with the first plant cultivation and weed vegetation phase.

The eight pollen horizon evolved between 60 and $40 \mathrm{~cm}$ (Fig. 18). Beech (Fagus) and hornbeam (Carpi$n u s)$ pollen dominate among woody vegetation elements. At the same time, weed composition has changed dramatically, and the proportion of herbaceous pollen (NAP) exceeded $60 \%$. In this level, the natural forest steppe became anthropogenic steppe vegetation, where woody vegetation (in the form of gallery forest) subsisted only in the active Tisza floodplain, in deeper locations with high groundwater level. Both crop production and animal hus-

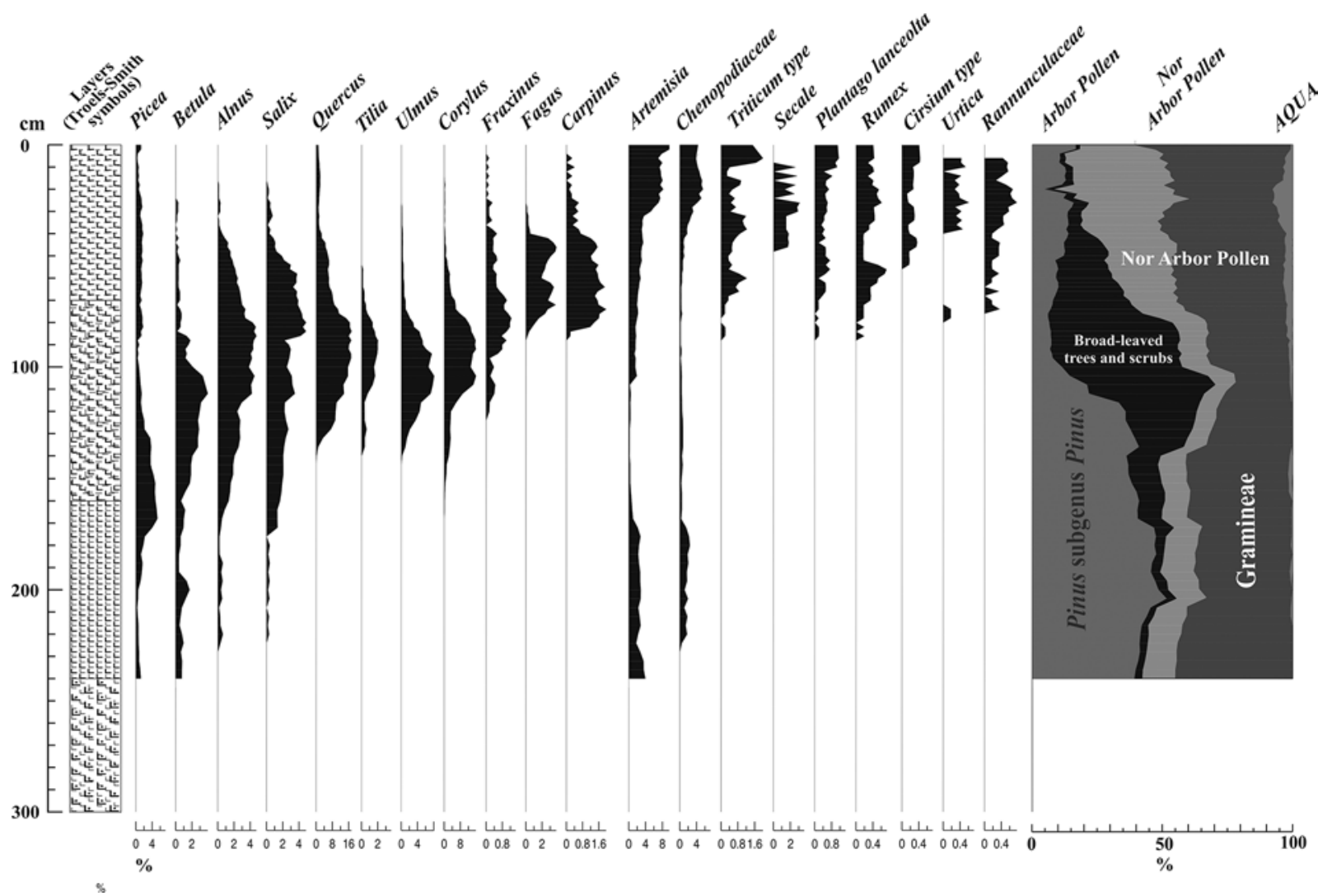

Fig. 18. Pollen analytical results from the undisturbed core sequence of an infilled point-bar channel in Rokkant-földek at Rákóczifalva

${ }^{57}$ Bernátsky 1914; Rapaics 1918; Chapman 1994, Chapman 1997, Chapman 2017; Chapman et al. 2009; Magyari $e t$ al. 2012.
${ }^{58}$ SüMegi 1989, SüMegi 1995, SÜMEgi 1996, SüMegi 2005; SÜMEGI et al. 2012, SÜMEGI et al. 2013b. 
bandry could have been significantly increased on the basis of the pollen ratio of cultivated plants and weeds. This horizon can be identified with the end of the Copper Age and the entire Bronze Age.

The ninth pollen zone developed between 40 and $25 \mathrm{~cm}$, where arboreal pollen ratio decreased to below $30 \%$ (Fig. 18). This significant change began in the Hungarian Great Plain at the end of the Bronze Age and the beginning of the Iron Age.

The tenth pollen horizon evolved between 25 and $15 \mathrm{~cm}$, which is the level of the Migration Period. The ratio of cultivated plants such as Triticum type, Secale, cereal show significant fluctuations. At the same time, the proportion of weeds (Rumex, Urtica, Plantago lanceolata, Ranunculus, etc.) spreading to trampling, chewing, grazing and the pollen of grasses, wormwood, pigweed has become dominant. AP ratio was below $20 \%$ in this level of the profile. The area was continuously inhabited during the Migration Period, and the communities continued to carry out extensive livestock farming and cereal production in varying intensity.

The pollen zone of the medieval period developed from $15 \mathrm{~cm}$ to the surface. It is probable that postmedieval levels have dried up and destroyed during soil formation processes. During the medieval period, the impact of crop production is stronger and more stable. Weed vegetation transformed compared to the Migration Period and as a result, mosaics and zones of crop production and animal husbandry could develop and stabilize in the area. It is likely that house groups or farm-like settlements with stable dirty roads evolved in the area during the medieval period.

\section{Interpretation of pollen results}

Based on the exogenous geological, geomorphological and sedimentological data, the pollen profile was formed in a Pleistocene residual surface, i.e. in a point bar channel of a point bar series rising above the Tisza alluvium. The Pleistocene point bar is probably of Danube origin, and consequently, its mineral composition and sedimentological development were separated from the sedimentary systems of the Tisza River. We were able to carry out a comprehensive sedimentological and geochemical study of the full development of the point bar channel. In addition, we could evaluate the development of the study area on the basis of the environment historical analysis of the profile from the end of the Pleistocene to the end of the medieval period. Despite the outstanding geomorphological and sedimentological results regarding human settlements, the most significant environmental historical data were provided by pollen analytical results. The pollen material was moderately well and well preserved and statistically evaluable from the end of the Pleistocene to the end of the medieval period.

The most important feature of pollen material is that pollen composition indicates forest steppe vegetation ${ }^{59}$ from the end of the Pleistocene, through the late glacial/post-glacial transition period until to the early Holocene period. On the basis of our results, this pollen composition corresponds to the northern part of the Late Pleistocene Eurasian forest steppe zone mixed with coniferous trees, or to the mixed-leafed taiga forest steppe in the Altai basin. ${ }^{60}$ These pollen data clearly support the models based on quartermalacological data. ${ }^{61}$ According to these in some regions of the Great Hungarian Plain, in the Pannonian forest steppe zone, there was a natural shift from cold forest steppe (in the Late Pleistocene) to temperate forest steppe (in the Holocene) on a regional and local level as well.

Thus, the concept that explains the development of the entire forest steppe zone with human effects in the Great Hungarian Plain, although this theory has survived to the present day, cannot be sustained anymore. In areas of hundreds of square kilometres at the regional level and in some square kilometers at the local level, it could be proved that a natural temperate steppe-forest steppe evolved in some parts of the Great Hungarian Plain ${ }^{62}$ at the end of the Pleistocene and at the beginning of the Holocene. Based on the previous results and analysis of different areas, due to the mosaic environmental conditions small local temperate steppe regions and patches developed in the forest steppe zone at the beginning of the Holocene; based on our previous data, mainly due to edaphic reasons. ${ }^{63}$ In

2010.

${ }^{59}$ Allen et al. 2000; Prentice et al. 1996; Magyari et al.

${ }^{60}$ SÜMEGI 1996; SÜMEGI et al. 1999, SÜMEGI et al. 2013a; MAgYAR et al. 2014; TÖRŐCSIK et al. 2015; TÖRŐCSIK-SÜMEGI 2016.

${ }^{61}$ SÜMEGI 1989, 1995, SÜMEGI 1996, SÜMEGI 2005, SÜMEGI
${ }^{62}$ SÜMEGI 1989, SÜMEGI 1995, SÜMEGI 1996, SÜMEGI 2005.

${ }^{63}$ SÜMEgI 1989, SÜMEGI 1996, SÜMEGi 2011; SÜMEGI $e$ t al. 2005, SÜMEGI et al. 2012, SÜMEGI et al. 2013b; TÖRŐCSIK et al. 2015; TÖRÖCSIK-SÜMEGI 2016.

2007. 
other words, parallel vegetation development evolved in the basin caused by mosaic environmental conditions. Despite increasing human effects, this parallel development has survived until the $19^{\text {th }}$ century, until the spread of industrial civilization and water regulation. The parallel vegetation development was, of course, influenced by human effects as well. However, their development and the magnitude of human effects were very different from each other. They were not homogenous as it was suggested by John Chapman. ${ }^{64}$ There was not a comprehensive system in the development of the vegetation of the Great Hungarian Plain as a result of the different ecoregions. ${ }^{65}$ The mosaic effect persisted in the vegetation despite the gradually increasing human impact at the beginning of and during the Neolithic. At the same time, as a result of plant cultivation, animal husbandry, human settlings and paths in the study area, a diverse composition of weed vegetation developed between the Neolithic and the Migration Period. Cereals, including Triticum type and Secale, indicate a significant fluctuation in the level of the Roman Age, including the Sarmatian era and the Migration Period and the level of the Gepids Kingdom. At the same time, the ratio of weeds (Rumex, Urtica, Plantago lanceolata, Ranunculus, etc.) spreading to trampling, chewing and grazing and the amount of grasses, wormwood and pigweed has become dominant. Arboreal pollen ratio was below $20 \%$ in this horizon of the profile.

During the Roman Age and Migration Period and the era of the Sarmatian and the Gepids Kingdom, the area was continuously inhabited, and the alternating communities carried out extensive animal husbandry that was supplemented by cereal cultivation, the latter with varying intensity.

These results clearly support the archaeobotanical analysis of Farkas-major at Apc and Baj-puszta at Hatvan archaeological sites during the Sarmatian period when a significant amount of millet, barley, emmer and einkorn occurred. Among wheat, which requires more advanced agrotechnology, spelt turned up as well. Not only the grain of it was found but also other remains of the plant referring to local plant cultivation and processing. ${ }^{66}$

These data support the plant remains (millet, wheat, barley) of a Gepids site called Eperjes-Csikóstábla ${ }^{67}$ and the local cereal cultivation ${ }^{68}$ in Szolnok-Zagyvapart site. ${ }^{69}$ Surprisingly, at the Sarmatian, Late Sarmatian, and Gepids sites, archaeobotanical analysis reveals the same cultivated cereal crops in the same amount and quality. However, the Sarmatian communities are considered nomadic, while archaeologists and archaeobotanists characterize the Gepids with a settled lifestyle. ${ }^{70}$ Based on geoarchaeological and environmental historical data so far, the existence of land management and nomadic livestock breeding due to the mosaic-like environment in the Carpathian Basin is impossible. ${ }^{71}$ Instead, extensive livestock breeding, ${ }^{72}$ a special grazing form has evolved that utilize an area in specific rotations. Nonetheless, the Sarmatian (and of course, other communities') nomadic lifestyles is steady. It seems that this is a deeply embedded historical theory in Hungarian archaeology and history, which is unwavering by contradictory data and facts. It is assumed that Eastern European origin and equestrian lifestyle is the strong simplification of the nomadic lifestyle in the Hungarian archaeology.

It is likely that the good relief, protective features, the diverse and fertile soil conditions and the proximity of rivers and creeks have played a prominent role in the continuous use of the area. Similar settlements ${ }^{73}$ with a completely similar morphological situation can be found in several places in the Middle Tisza region (Tiszapüspöki, Kengyel, Szolnok, Törökszentmiklós). Though, these similar exogenous geological features have so far been ignored in the interpretation of the settling of the Sarmatian and Gepids.

Based on our data, Gepids, and previously Sarmatian communities settled in a completely altered vegetation environment in the peninsula-like residual surface of the Tisza valley that had great importance concerning the protection and natural factors. We were not able to determine the Sarmatian and Gepids communities' vegetation environment more precisely, even with radiocarbon analysis, because the margin of error of radiocarbon analysis is such wide that it covers the $4^{\text {th }}$ and $6^{\text {th }}$ centuries, the level of the Sarmatian and Gepids' settling. This could only be refined by archaeobotanical and archaeozoological analysis of samples from Gepids objects, including wells. With the exception of our data, we do not have such comprehensive data regarding Gepids settlements at the moment,

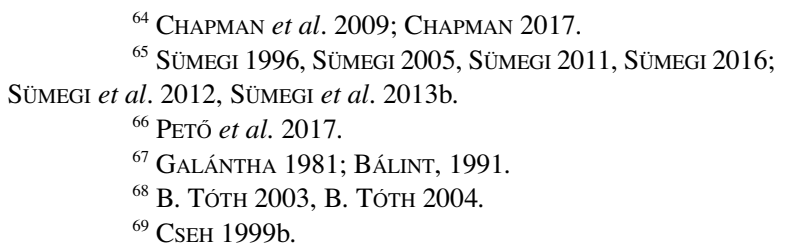

${ }^{64}$ Chapman et al. 2009; Chapman 2017.

${ }^{65}$ SÜMEGI 1996, SÜMEGI 2005, SÜMEGI 2011, SÜMEGI 2016; SÜMEGI et al. 2012, SÜMEGI et al. 2013b.

${ }^{66}$ PETỎ et al. 2017.

${ }^{67}$ Galántha 1981; Bálint, 1991.

${ }^{68}$ B. То́тн 2003, B. То́тн 2004.

${ }^{69}$ CSEH 1999b.

2017.

${ }^{70}$ Gyulai 2001, Gyulai 2003, Gyulai 2010; Pető et al.

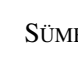

${ }^{71}$ SÜMEGI 2016; TÖRŐCSIK-SÜMEGI 2016, TÖRŐCSIK-

18; TÖRÖCSIK et al. 2019.

${ }^{72}$ GYÖRFFY 1983.

${ }^{73}$ KŐHEGYI 1984; VADAY 1989; VÖRÖS 1998; ISTVÁNOVITSKulCSÁr 2011, IsTVÁNOVITS-KulCSÁr 2018; CSEH 1986, CSEH 1990 , CSEH 1992, CSEH 1993, CSEH 1999b. 
only archaeozoological ${ }^{74}$ and sporadic archaeobotanical data ${ }^{75}$ Compared to the previously published scattered data regarding Sarmatian settling, several natural historical results have been published during the last years in order to reconstruct the Sarmatian plant cultivation and animal breeding. ${ }^{76}$ It is clear from the archaeobotanical (anthracological) analysis of Sarmatian and Gepids' objects of the Rákóczifalva site that construction wood derived from the Tisza alluvium hardwood gallery forest. At the same time, archaeozoological findings suggest remarkable livestock in the era of the Gepids Kingdom.

At the end of the Migration and during the medieval Period, the stabilization and increase of land cultivation was observed. As a result, a significant, though diffuse structured settlement and permanent roads could develop in the study area and one of the greatest of human impact evolved in the archaeological site of Rákóczifalva.

\section{Macrobotanical analysis}

The Sarmatian anthracological assemblage of Rákóczifalva-Bagi-földek archaeological site indicates oak (Quercus) dominance. Only oak remains were found in the samples of 4 objects, in a relatively large number.

Table 2. Anthracological remains from Sarmatian, Late Sarmatian and Gepids objects at Rákóczifalva

\begin{tabular}{|c|c|c|c|c|c|c|}
\hline \multirow[t]{2}{*}{ Rokkant föld archaeological site } & \multicolumn{2}{|c|}{ Sarmatian } & \multicolumn{2}{|c|}{ Late Sarmatian } & \multicolumn{2}{|l|}{ Gepid } \\
\hline & $\%$ & $\mathrm{i}$ & $\%$ & $\mathrm{i}$ & $\%$ & $\mathrm{i}$ \\
\hline Abies alba (fir) & 63 & 124 & & & 1,7 & 18 \\
\hline Acer (maple) & & & 7,8 & 17 & 3,6 & 39 \\
\hline Fraxinus (ash) & 5,6 & 11 & & & 29,1 & 311 \\
\hline Pirus/Crataegus/Cydonia (pear/hawthorn/quince) & 12,2 & 24 & & & & \\
\hline Populus/Salix (poplar/willow) & & & 23,7 & 52 & & \\
\hline Prunus (prunus) & & & 67,5 & 148 & & \\
\hline Quercus (oak) & 18,8 & 37 & 0,9 & 2 & 64,4 & 688 \\
\hline Ulmus (ulm) & & & & & 1,2 & 13 \\
\hline Vitis vinifera (grapes) & 0,4 & 1 & & & & \\
\hline SUMMA (individuals = i) & \multicolumn{2}{|l|}{197} & \multicolumn{2}{|l|}{219} & \multicolumn{2}{|l|}{1069} \\
\hline
\end{tabular}

The anthracological material of the Rokkant-földek site is as follows. $87.8 \%$ of the anthracological assemblage proved to be oak (Quercus), 4.5\% is elm (Ulmus), 4-3\% is Prunus, 1.5\% is pear/hawthorn/quince (Pirus/ Crataegus/Cydonia) and 1.3\% is beech. In addition, 1-1 fragment of a willow/poplar tree (Salix/Populus), maple (Acer), alder (Alnus) and grapes (Vitis vinifera) occurred. The diversity of wood fragments may indicate that due to the decrease in the number of forest species, for example oak, although it provides the largest volume of charcoal fragments in the anthracological material, other species had to be used as firewood or construction wood as well. In addition, in order to increase the area of arable land, deforested trees could all be used for daily cooking and heating, or for making tools.

In the Late Sarmatian period, the amount of oak decreases to $66 \%$, while the ratio of elm rises to $20.4 \%$; the ratio of maple, ash (Fraxinus), alder and Prunus is 3-3\%. A few pieces of hornbeam (Carpinus) and willow/poplar charcoal turned up as well. The presence of Prunus and pear/hawthorn/quince indicate gardening that reflects the cultural and agricultural effect of the Roman age. This is supported by the presence of grape charcoal (Table 2). The presence of these fruit charred wood fragments contradicts to the Sarmatian nomadic lifestyle ${ }^{77}$ theory. Since charcoal fragments are local remains, these plants surely existed in the vicinity of the Sarmatian settlement. It is likely that fruit trees, just like today, could be located on the northern edge of the settlement with the most favourable microclimatic conditions, on the south-facing hillside. According to the remarkable number of fir trees (Abies alba) (Table 2) found in Sarmatian objects, there was a stronger connection between the Sarmatian community living in the Great Hungarian

${ }^{74}$ SZABÓ-VÖRÖS 1979.

${ }^{75}$ BÁLint 1991; B. Tóth 2003, B. Tóth 2004.
${ }^{76}$ GyUlai 2001, GyUlai 2003, GyUlai 2010; Petỏ et al. 2017; BÖKÖNYI 1976; VADAY-VÖRÖS 1980; KULCSÁR-VÖRÖs 1989; VÖRÖS 2004, VÖRÖS 2012; TUGYA-LICHTENSTEIN 2011.

${ }^{77}$ IsTVÁNOVITS-KULCSÁR 2011.

Acta Archaeologica Academiae Scientiarum Hungaricae 71, 2020 
Plain and the communities living in the highland zone of the Carpathian Basin than it has been previously revealed. ${ }^{78}$ A total of 1069 pieces of charcoal fragments were found and identified in 13 samples of Gepid ( $6^{\text {th }}-7^{\text {th }}$ century) objects. $64.4 \%$ (688 pieces) of the charcoal fragments belong to oak (Quercus) genus. Ash (Fraxinus) is also represented in a significant proportion, with a value of $29.1 \%$ (311 pieces). In addition, the ratio of maple (Acer) is lower which accounts for 3.6\% (39 pieces) of the total material; the ratio of fir (Abies) is 1.7\% (18 pieces), while the ratio of elm (Ulmus) is $1.2 \%$ (13 pieces). Charcoal fragments clearly indicate the presence of a hardwood gallery forest (oak-ashelm) in the vicinity of the settlements. At the same time, the presence of fir (Abies) is a particular surprise, as it is an alien element in the Great Hungarian Plain, especially in its centre of warm and dry climate (Fig. 6). However, in the eastern part of the Gepid Kingdom, in the higher mountains encircling the Transylvanian Basin, including the Carpathians and Transylvanian mid-Mountains, there are larger forests of this species at the height of 1300 meters. ${ }^{79}$ As a result, the presence of fir charcoal indicate exportation, and it cannot be excluded that fir trees (that originate clearly from mountainous areas) have been utilized in connection with a ceremony (settlement, house warming).

\section{Archaeozoological analysis}

The vertebrate fauna analysis from the Sarmatian, Late Sarmatian and Gepids objects supported the combined use of the deeper Tisza alluvium that has good hydrological characters, oxbows and water outlets, and the flood-free, dry surfaces suitable for grazing fields, animal husbandry and plant cultivation. This is in concordance with the results of pollen analysis.

A low amount of Sarmatian and Gepids finds have been found in the area of the Rákóczifalva archaeological site, while the Late Sarmatian finds represent a very small amount. A similar amount of animal bones was found in Sarmatian and Gepids objects. 886 pieces of Sarmatian archaeozoological material originate from 88 objects, while 1012 pieces of Gepids' bones turned up in only 11 objects. This is the reason why there is a big difference in the maximum number of individuals, as it was calculated on the basis of objects (Table 3).

In every Period came to light animal bones from ditches, pits and houses too.

The number of Sarmatian bones (886 pieces) is considered to be medium, and the number of identifiable and evaluable bones is 866 pieces. $97.1 \%$ of the findings were derived from domestic animals, with cattle being the most common, followed by sheep, goat, horse, pig and hen. A larger amount of dog and cat bones were also found. Results prove hunting and fishing. Similar bone ratios can be seen in the Hajdúnánás-Fürjhalom site as well: $98.13 \%$ of the finds originate from domestic animals, and the order of the species is the same as in case of the Rákóczifalva site ${ }^{80}$ Compared to the more than 6,000 pieces of Hajdúnánás material, a very small amount was found in Lajosmizse, where $46.8 \%$ of the 158 pieces of bones was identified as cattle. Further order of species was sheep, horse, pig, hen, ${ }^{81}$ which was identical to the Rákóczifalva assemblage.

The same order could be revealed at the Endröd 170 site, ${ }^{82}$ where 388 pieces of the 894 identifiable animal bones originated from cattle, representing $43 \%$ of the whole material. The number of sheep/goat bones was a little less than the number of cattle bones. Hen bones were not, but a goose bone has been found. Hunting was proved by two roe deer and one rabbit bone. Shell fragments have been found in Endröd, but there was no evidence of fishing. ${ }^{83}$

The number of Late Sarmatian bone material is less than one-third of the Sarmatian and approximately is a quarter of the number of Gepids' bones. $97.49 \%$ of the 244 animal bones were domestic animal remains. There is no justification for hunting, but a few fragments of fish bones and tortoise-shells indicate that besides domestic animal aquatic animals were also consumed. The number of Late Sarmatian domestic animals was as follows: cattle, horse, pig, sheep/goat and hen. The number of Late Sarmatian bone material is lower; however, the order of the species was reversed: the number of horse and pig bones preceded the number of sheep/goat. In the archaeological site of Dunavecse-Ugordáció I. site, in the level of the $4^{\text {th }}-5^{\text {th }}$ century (158 identifiable bones) the following ratio could be revealed: sheep/goat bone ratio was the highest (37\%), followed by cattle (36.1\%), pigs (15.2\%), horses $(7.6 \%)$, poultry $(3.2 \%)$ and dogs $(0.6 \%){ }^{84}$

\footnotetext{
${ }^{78}$ ISTVÁNOVITS-KULCSÁR 2018.

${ }^{79}$ FeURDEAN-Willis 2008.

${ }^{80}$ Gál 2010, 209, Table 1.

${ }^{81}$ KULCSÁR-VÖRÖS 1989, 92.
}

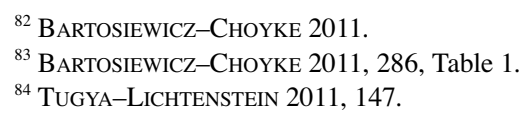


Table 3. Species lists with number of individuals (Sarmatian, Late Sarmatian, Gepid)

\begin{tabular}{|c|c|c|c|c|c|c|c|c|c|}
\hline \multirow[b]{2}{*}{ Species } & \multicolumn{3}{|c|}{ SARMATIAN } & \multicolumn{3}{|c|}{ LATE SARMATIAN } & \multicolumn{3}{|c|}{ GEPID } \\
\hline & $\frac{\bar{\omega}}{\bar{Z}}$ & $\%$ & 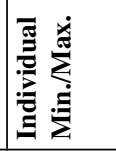 & $\frac{\hbar}{\bar{Z}}$ & $\%$ & 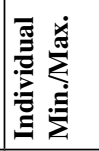 & $\frac{\hbar}{\bar{Z}}$ & $\%$ & 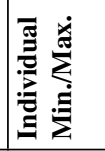 \\
\hline Cattle & 314 & 36,21 & $6 / 64$ & 91 & 37,91 & $8 / 22$ & 275 & 28,9 & $8 / 22$ \\
\hline Sheep & 34 & \multirow[t]{3}{*}{24,56} & $4 / 11$ & 2 & \multirow[t]{3}{*}{10,83} & \multirow[t]{3}{*}{$2 / 10$} & 10 & \multirow[t]{3}{*}{31,9} & $2 / 2$ \\
\hline Goat & 4 & & $2 / 2$ & - & & & 1 & & $1 / 1$ \\
\hline Sheep or goat & 175 & & $4 / 24$ & 24 & & & 292 & & $9 / 19$ \\
\hline Pig & 44 & 5,07 & $5 / 24$ & 43 & 17,92 & $5 / 9$ & 94 & 9,9 & $8 / 18$ \\
\hline Horse & 71 & 8,19 & $5 / 34$ & 71 & 29,58 & $4 / 15$ & 43 & 4,5 & $3 / 9$ \\
\hline Hen & 1 & 0,12 & $1 / 1$ & 1 & 0,42 & $1 / 1$ & 38 & 4,0 & $4 / 11$ \\
\hline Dog & 166 & 19,26 & $11 / 28$ & 2 & 0,83 & $1 / 2$ & 108 & 11,4 & $5 / 5$ \\
\hline Cat & 32 & 3,69 & $3 / 3$ & - & - & - & 5 & 0,5 & $1 / 1$ \\
\hline Domestic species & 841 & 97,10 & $41 / 191$ & 234 & 97,49 & $21 / 49$ & 869 & 91,1 & $41 / 88$ \\
\hline Goose & 2 & 0,23 & $2 / 2$ & 1 & 0,42 & $1 / 1$ & 8 & 0,8 & $1 / 1$ \\
\hline Domestic or wild species & 2 & 0,23 & $2 / 2$ & 1 & 0,42 & $1 / 1$ & 8 & 0,8 & $1 / 1$ \\
\hline Reed deer & 1 & 0,12 & $1 / 1$ & - & - & - & - & - & - \\
\hline Europoean pond turtle & 1 & 0,12 & $1 / 1$ & 1 & 0,42 & $1 / 1$ & 2 & 0,2 & $1 / 2$ \\
\hline Catfish & 1 & 0,12 & $1 / 1$ & - & - & - & 2 & 0,2 & $1 / 2$ \\
\hline Pike & 2 & 0,23 & $1 / 2$ & - & - & - & 2 & 0,2 & $2 / 2$ \\
\hline Fish & 6 & 0,69 & $1 / 3$ & 2 & 0,83 & $1 / 2$ & 40 & 4,2 & $1 / 5$ \\
\hline Wild species & 11 & 1,28 & $5 / 8$ & 3 & 1,25 & $2 / 3$ & 46 & 4,8 & $5 / 11$ \\
\hline Rodent & 7 & 0,81 & $2 / 5$ & 1 & 0,42 & $1 / 1$ & 4 & 0,4 & $1 / 2$ \\
\hline Bird & 5 & 0,58 & $2 / 4$ & 1 & 0,42 & $1 / 1$ & 27 & 2,9 & $3 / 6$ \\
\hline Other species & 12 & 1,39 & $4 / 9$ & 2 & 0,84 & $2 / 2$ & 31 & 3,3 & $4 / 8$ \\
\hline Mussel & 3 & - & - & - & - & - & 20 & - & - \\
\hline Snail & - & - & - & - & - & - & 13 & - & - \\
\hline Unidentified mammal & 17 & - & - & 4 & - & - & 28 & - & - \\
\hline Total remains & 886 & 100 & $52 / 210$ & 244 & 100 & $26 / 55$ & 1012 & 100 & $51 / 108$ \\
\hline
\end{tabular}

Most of the mid-size (979 pieces) animal bones of Gepids' objects, similarly to the Sarmatian findings, can be interpreted as kitchen waste. It was hard to find whole bones that indicate that meat and bones were cut together during cooking. In spite of that, most of the bones could be identified. Only 28 bones were unidentifiable and found to be remnants of large or small mammals (Table 3). The Gepids' finds contained the remains of domestic animals, wild birds that could not be identified on a species level, fish and aquatic animals. Findings indicating hunting did not turn up, even antler fragments that can be collected without killing the animal.

This is the only archaeological period in the Rákóczifalva site, where cattle bones are not the most common; although the amount of cattle bones are not much less than the number of ruminants (sheep and goat, 3\% and 28 pieces). Interestingly pig bones are more frequent than horse bones. Among domestic animals, horses were rarely cut off - probably because of their high value. Poultry remains were also found, mostly hen bones and its ratio is roughly similar to horse bones. Some goose bones were found as well. In addition to the remains of meat-producing animals, bones of dogs and cats were also discovered. Probably dogs chewed more bones; there are signs of teeth on 16 findings including cattle, ruminants, pigs and even hens. It is not possible to estimate the number of bones that have been entirely eaten up. The cartilage bone ends of young poultry, especially hens, could be easily consumed by cats or even by humans that result in taphonomic losses. A significant number of fish bones refers to fishing and the extensive use of the alluvium.

We calculated for each species the minimal and maximal number of individuals (Table 3) for the Sarmatian, Late Sarmatian and Gepids period. In the first case, we calculated the number of bones for all of the same species of the site, and in case of the maximum number of individuals, we took the objects into one-one unit, calculated separately for each object and then summed up the results. The actual number of individuals of each species can be between the two values; the smallest number of individuals is undoubtedly below, and the maximum is overestimated. 
In the vicinity of the settlement, grazing livestock of 21-35 individuals in the Sarmatian period, 14-47 individuals in the Late Sarmatian period and 23-53 individuals (sheep, goats, cattle, horses) in the Gepids era was required. These numbers do not seem to be significant, especially since we do not have information about the number of years the Gepids' settlement was inhabited. Nevertheless, the continuous catering, grazing and winter feeding of a few dozen animals could be challenging. It should also be taken into account that not the entire Gepids settlement was excavated, meaning the number of individuals was definitely much higher.

In all three periods, the ratio of cattle is around 30\%. It is highest in the Late Sarmatian period (37.91\%) and lowest in the Gepids era $(28.9 \%)$, so it is not around $50 \%$ that can be observed very often. In HajdúnánásFürjhalom-dülö site, the Sarmatian cattle bone ratio is close to $50 \%(47.46 \%) .{ }^{85}$ Based on the number of bones, in case of a lower proportion of cattle, the domestic animal population is more balanced.

The 314 pieces of Sarmatian cattle bones represent $36.21 \%$ of the findings. It was the most common species; the smallest number of individuals was only 6, but the highest number of individuals per object was quite high, 64 individuals. This maximum number of individuals is certainly excessive since not all of the objects can be considered as independent households. This large amount is due to the fact that the objects are taken as a unit in this calculation method. Since 88 Sarmatian objects contained bones, most of the cattle bones as well, so the number of individuals is in concordance with that number.

The number of Late Sarmatian cattle bone is 91 pieces; the number of individuals is between 8 and 22. On the basis of the minimum number of individuals, the number of young animals is higher, one of them is only $1 / 2-3 / 4$ years old, it was slaughtered during winter. 3 more individuals were young, between 1 and 3 years old, one animal was adult (between 3 and 4 years old) and only one animal was mature. In contrast, the maximum number of individuals indicate a similar ratio of young and adult animals.

The 275 cattle bones represent $28.9 \%$ of the detectable findings. The bones come from at least 8 up to 22 animals; their age distribution is mixed. Out of the 8 individuals, one was juvenile, which is 1-3 years old in case of cattle. One was subadult that is 3-4 years old, 3 individuals were adults, over 4 years old. One individual was 6 -7 and one was 6-8 years old, already mature. One specimen died or was slaughtered as an old animal. In total more elder animals were slaughtered than young ones.

In case of the maximum number of individuals, the age distribution is more heterogenic. The number of young animals is 7, 3 individuals are already adults, 7 specimens are adults, 2 are matured and 1 is old and there were 2 cattle of undetermined age. Based on the age distribution of cattle, young and adult animals were slaughtered in each period. Young calves were slaughtered for their tastier flesh. Older animals served the man with their strength (bull) and milk (cow).

The metatarsus bones of 8 cattle could be used to calculate the withers and to determine the sex of the animal. The smallest cattle was a $109 \mathrm{~cm}$ tall cow; other cows were 111,113 ad $114 \mathrm{~cm}$ tall. The tallest cow was $117 \mathrm{~cm}$ tall. One specimen was a bull, and its height was $122.8 \mathrm{~cm}$ (Fig. 19). ${ }^{86}$ In the Late Sarmatian period the withers of cattle is between 114 and $117 \mathrm{~cm}$.

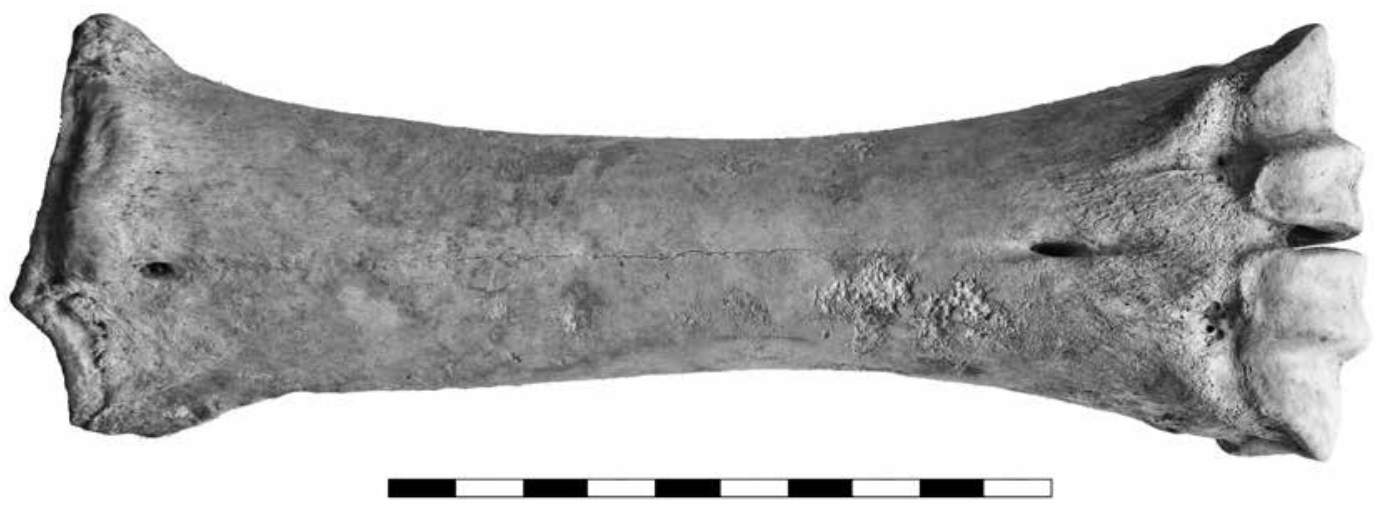

Fig. 19. Sarmatian bull metacarpus

\footnotetext{
${ }^{85}$ Gál 2010, 209, Table 1.
}

${ }^{86}$ NOBis 1954; MatOLCSI 1970. 
The $236 \mathrm{~mm}$ long bone derived from an approximately $126 \mathrm{~cm}$ tall cow. ${ }^{87}$ This cow is considered to be large compared to other samples from different periods. Bones suitable for withers calculation from Celtic, Sarmatian, Late Sarmatian, bones from the $4^{\text {th }}-5^{\text {th }}$ century, the late Migration Period and Arpadian Age occurred and were used for calculation; each animal was a cow. The height of the Celtic animal was small, around $107 \mathrm{~cm}$. The Sarmatian cows were 111 and $117 \mathrm{~cm}$ tall, the $4^{\text {th }}-5^{\text {th }}$ century animals were $114-115 \mathrm{~cm}$, from the late Migration Period they were 106, 114, 116 and $122 \mathrm{~cm}$ tall, from the Arpadian Age it was a small cow, only $108 \mathrm{~cm}$ tall.

There were 29 chewed Sarmatian cattle bones, body regions that are rich and poor in meat occurred as well. Only a femur (Fig. 20) were chewed except for one pelvic bone. A dozen carved bones occurred with a sign of cutting in the vertebra, rib, scapula and jawbone. Bones were carved for $7-15 \mathrm{~cm}$ pieces.

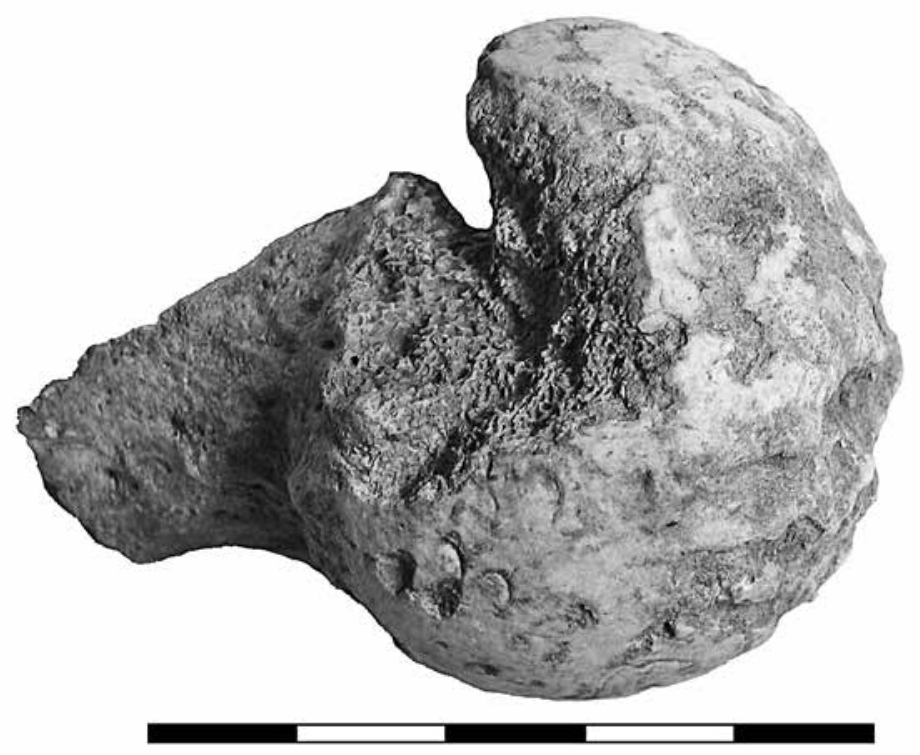

Fig. 20. Chewed caput femoris of a cattle

Regarding Late Sarmatian bones, only 3 cattle bones were chewed; although the number of dog bones was lower as well compared to Sarmatian findings. All of the 3 bones were metatarsus and metacarpus bones.

In the Gepids material, the number of chewed bone is low as well. Only 7 pieces were found: 4 phalanges, one cochlea, one calcaneus and one tibia. The number of sliced cattle bones is two, one of them is a tibia the other is a $5 \mathrm{~cm} \log$ horn fragment with parallel marks of cut and pole-axe (Fig. 21). Little is known about the use of horns, but Sarmatian sliced horns indicate the use of them. In Orosháza-Községporta-Szücs-tanya archaeological site, more pieces of sliced horns occurred. ${ }^{88}$ The distribution of cattle bones regarding body region is even in all period of time, bones rich and poor in meat occur as well (Table 4). However, while during the Sarmatian period the limb region, during the Late Sarmatian and Gepids periods the bone volume of the head region dominated. The bone volume of the head region is increased by the fallen tooth remains. There were 27 pieces in the Sarmatian, 5 in the Late Sarmatian and 22 in the Gepids material. Apart from these, most of the bones derived from the body region during the Gepids period. These include high-quality meat bones, vertebra and ribs. Even today, sirloin, tenderloin, white and black roast meat of the hind legs are the most valuable and most expensive meat types. The volume of ribs is high in the Sarmatian and Gepids period because the $50 \mathrm{~cm}$ long rib bones were cut into approximately $15-20 \mathrm{~cm}$ pieces that are ideal for cooking and roasting.

Sheep and goat bones are very similar; it can only be distinguished by a few features of some of the bones. In the Sarmatian assemblage, 34 sheep and 4 goat bones were found, while 175 pieces could not be identified (sheep/ goat), their combined ratio was $24.56 \%$. The number of individuals was between 10 and 37 . The youngest sheep was slaughtered at the age of six months and another animal was slaughtered a bit later but still as a young specimen (about 9 months to 2.5 years old). One animal was nearly adult (2.5-3.5 years old) and one was adult. One of the

${ }^{87}$ NoBis, 1954; CALKIN, 1960.

${ }^{88}$ TUGYA-RÓZSA 2012, 225-230.

Acta Archaeologica Academiae Scientiarum Hungaricae 71, 2020 
goats had already undergone tooth replacement, but its teeth were barely rubbed and was still young (Figs 22-23). The other goat's age could not be determined. Based on the bones identified as sheep/goat, the minimum number was 4 and each of them were young specimens. The maximum individual number in case of sheep was 11 , where two adults, one nearly adult and three young specimens could be identified. The age of five individuals could not be determined. In the case of sheep/goats, the number of young specimens was 10, while the number of adult and older animals was only 3 . However, the age of 11 animals could not be determined.

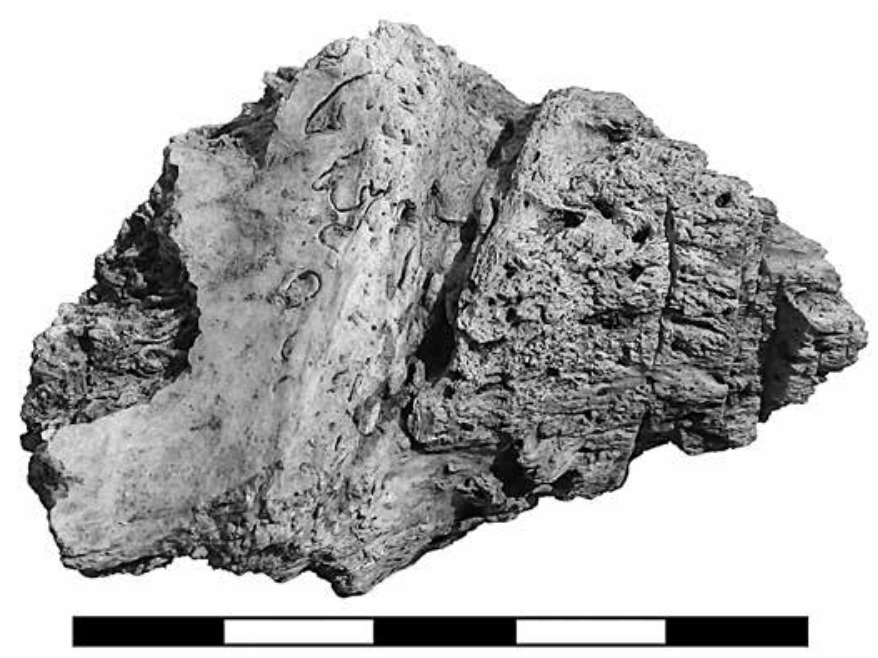

Fig. 21. Horn core fragment of a cattle with cutting marks

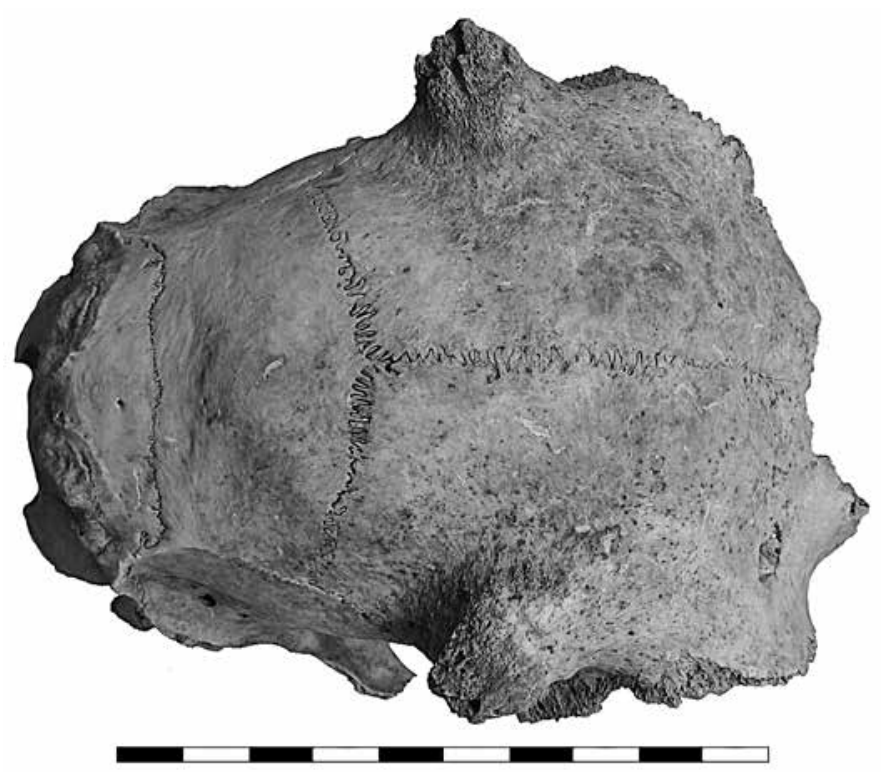

Fig. 22. Sarmatian goat skull 


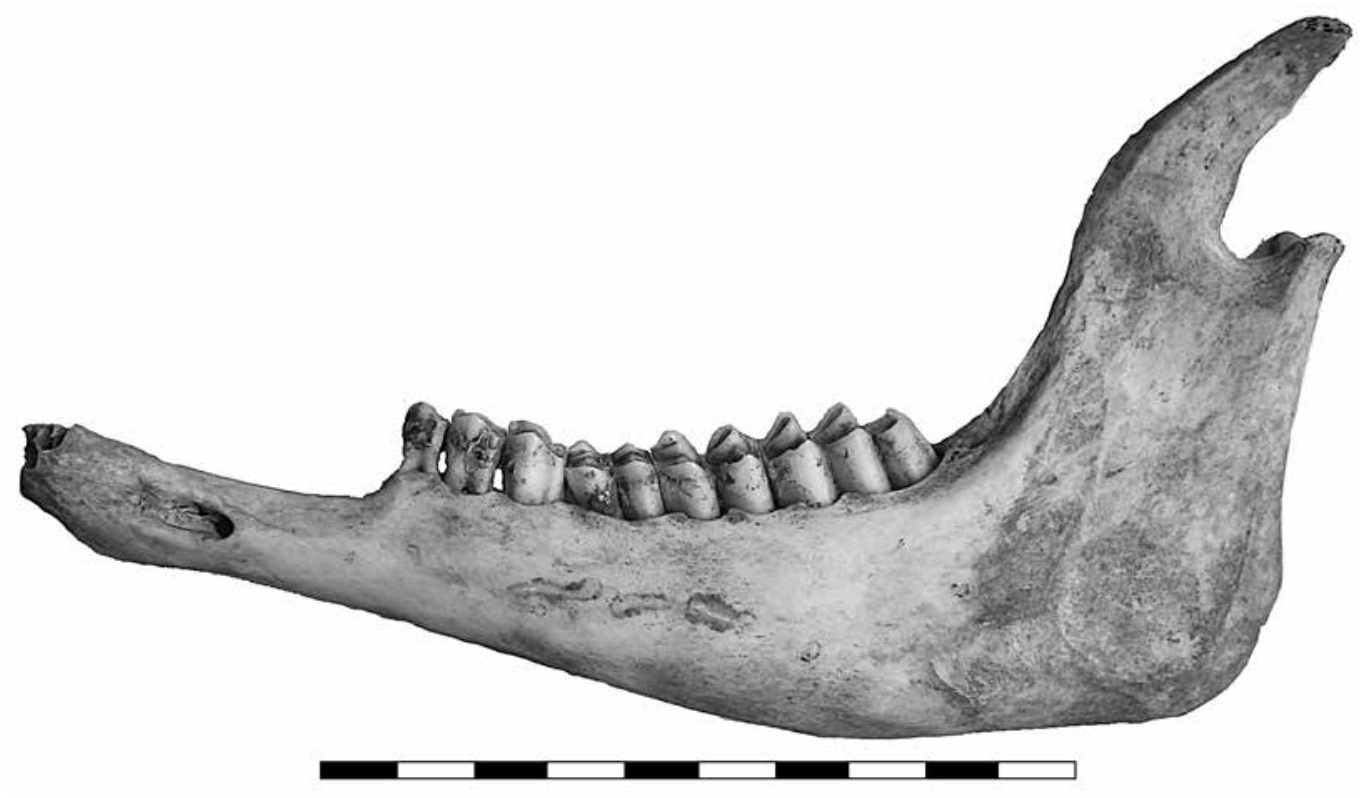

Fig. 23. Sarmatian goat jaw

The Late Sarmatian material contains 26 small ruminant bones, two of them derive certainly from sheep. Bones referring to goats did not turn up. Because of the lower number of bones, the number of individuals is much smaller, ranging from 2 to 10, of which only one specimen was young, all other were adult animals. Therefore, small ruminants were not raised mainly because of their meat, and they could use their milk, or even their wool in the case of sheep.

In the Gepids material, small ruminants include sheep and goats as well. Because of the high degree of similarity between the bones of the two species, it is difficult to distinguish them. 10 bones of the 303 small ruminant bones were identified as sheep, one as a goat, and 292 as either of these species. In general, sheep are more common in every period of time and goats are less frequent. Among the sheep/goat findings, several bones were chewed by dogs, most of them come from meat-rich regions of the body.

The age distribution of the individuals is mixed. Two sheep and one goat were adult specimen; the age distribution of the sheep/goat individuals was mixed. Based on the smallest number of individuals, one specimen was between 1 and 2 years old, and one was between 1 and 1.5 years old. Three animals were young (less than 2.5 years), one was nearly adult (2.5-3.5 years old) and three were adults.

Based on the highest number of individuals, the age of two sheep and one goat was adult. In the case of the 19 sheep/goats specimens there were young and adult animals in half to half ratio: nine specimens were juvenile, one of them was between 1-2 years old, one of them was younger than 1.5 years old and one between 1-2 years old. The age of the other six young animals could not be determined, but they were surely younger than 2.5 years old. Three animals were subadult, i.e. nearly adult and six were adult specimens. The age of one animal could not be determined. Surprisingly the remains of very young, i.e. younger than one-year-old animal did not occur.

The age distribution of the animals was mixed in each period of times: some of them was slaughtered at a young age, while others as an adult. The slaughtering of young animals clearly indicates the utilization of meat, while slaughtering the older ones' point to milk and wool utilization.

In the Sarmatian period in the case of small ruminants, most of the findings derived from the body region, mainly vertebra and ribs. Even in the Gepids period, the number of ribs were higher than other bones (Table 4).

Long bones derived only from Sarmatian objects from which the height of the withers of the sheep can be estimated. One animal was $58-59 \mathrm{~cm}$ and one was slightly larger than $61 \mathrm{~cm} .{ }^{89}$

${ }^{89}$ Teichert 1975. 


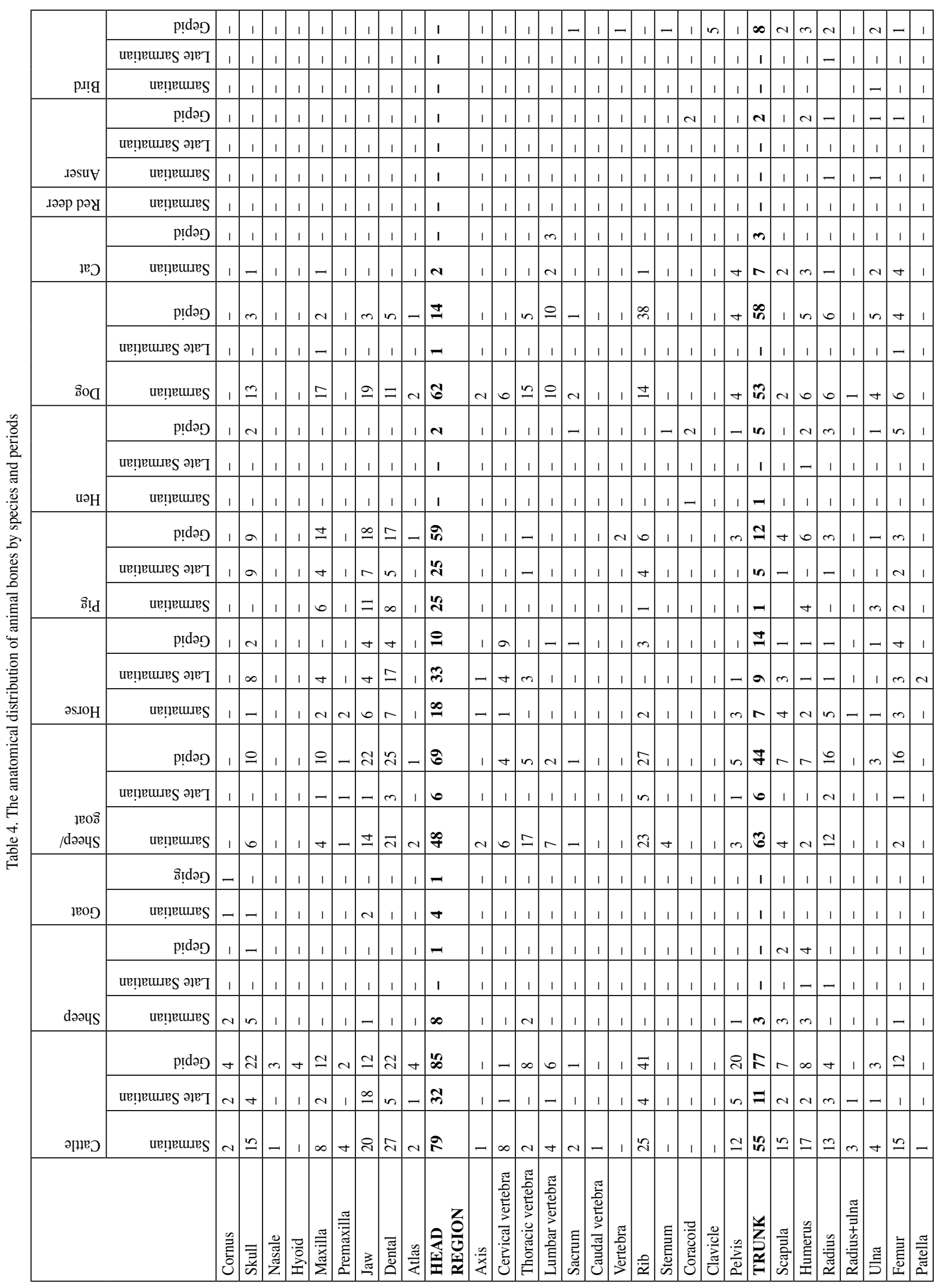

Acta Archaeologica Academiae Scientiarum Hungaricae 71, 2020 


\begin{tabular}{|c|c|c|c|c|c|c|c|c|c|c|c|c|c|c|c|c|c|c|c|c|c|c|}
\hline \multirow[b]{3}{*}{ p.!̣g } & p!̣də⿹ & $\mathrm{a}$ & & & $\approx$ & 1 & $\theta$ & & 1 & 1 & & $m$ & 1 & n & 1 & 1 & 1 & 1 & 1 & 1 & 1 & 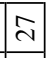 \\
\hline & 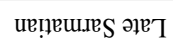 & & 1 & & - & 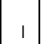 & & & 1 & 1 & 1 & 1 & 1 & 1 & 1 & 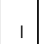 & 1 & 1 & 1 & 1 & 1 & - \\
\hline & 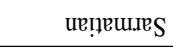 & - & 1 & o & a & 1 & 1 & 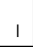 & 1 & 1 & 1 & - & 1 & - & - & 1 & 1 & 1 & - & - & 1 & in \\
\hline \multirow[b]{3}{*}{.әsuY } & p̦̣də⿹ & - & 1 & s & ๑ & 1 & 1 & 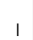 & 1 & 1 & 1 & 1 & 1 & & 1 & 1 & 1 & 1 & 1 & 1 & 1 & $\infty$ \\
\hline & иеппвшще & 1 & 1 & 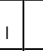 & $\mathrm{I}$ & 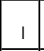 & - & & 1 & 1 & 1 & 1 & 1 & - & 1 & 1 & 1 & 1 & 1 & 1 & 1 & - \\
\hline & ивп̣ешлек & 1 & 1 & o & a & 1 & & 1 & 1 & 1 & 1 & 1 & 1 & & 1 & । & 1 & 1 & 1 & 1 & 1 & A \\
\hline Іәәр рәу & иеп̣ешіеs & 1 & 1 & । & 1 & 1 & - & 1 & 1 & 1 & 1 & 1 & 1 & - & 1 & 1 & 1 & 1 & 1 & 1 & 1 & - \\
\hline \multirow[b]{2}{*}{ Ieכ } & p!̣ळə઼ & 1 & 1 & 1 & 1 & 1 & 1 & 1 & 1 & 1 & 1 & 1 & 1 & 1 & $\sim$ & 1 & 1 & 1 & 4 & 1 & 1 & in \\
\hline & ивп̣еш.res & 6 & . & -9 & 2 & 1 & , & 1 & 1 & 1 & 1 & । & + & $\sigma$ & 1 & । & 1 & 1 & 1 & 1 & 1 & $\tilde{m}$ \\
\hline \multirow[b]{3}{*}{$80 \mathrm{C}$} & p̣̣də⿹ & m & 1 & -5 & A & 1 & 1 & 1 & 1 & - & 1 & & $=$ & $\simeq$ & 1 & 1 & 1 & 1 & 1 & 1 & 1 & $\stackrel{\infty}{0}$ \\
\hline & 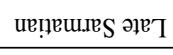 & 1 & 1 & 1 & - & 1 & 1 & 1 & 1 & 1 & 1 & 1 & 1 & 1 & 1 & 1 & 1 & 1 & 1 & 1 & 1 & 4 \\
\hline & ивп̣ешахS & 6 & $\sim$. & -5 & ले & 1 & 6 & 1 & $\mathrm{~N}$ & $m$ & & $n$ & - & $\Xi$ & 1 & । & 1 & 1 & 1 & 1 & 1 & $\stackrel{8}{0}$ \\
\hline \multirow[b]{3}{*}{ иәН } & p!̣də弓 & $\infty$ & 1 & 15 & 2 & $N$ & 1 & 1 & 1 & 1 & 1 & 은 & 1 & $\simeq$ & 1 & 1 & 1 & । & 1 & 1 & 1 & $\infty$ \\
\hline & иепџвшще & 1 & 1 & 1. & - & 1 & 1 & 1 & 1 & 1 & 1 & 1 & । & 1 & 1 & 1 & 1 & । & $\mathrm{I}$ & 1 & 1 & - \\
\hline & иепฺвш.геs & 1 & 1 & 1 & 1 & 1 & 1 & 1 & 1 & 1 & 1 & I & 1 & 1 & 1 & 1 & 1 & । & 1 & 1 & 1 & - \\
\hline \multirow[b]{3}{*}{ s!td } & p̣̣də⿹ & $m$ & . & -3 & $\bar{\sim}$ & 1 & 1 & 1 & - & - & 1 & 1 & 1 & $a$ & । & 1 & 1 & 1 & 1 & 1 & 1 & t \\
\hline & ивйешщеs әрт & $m$ & 1 & -0 & $\infty$ & 1 & N & & - & 1 & 1 & $\mathrm{~N}$ & 1 & in & 1 & 1 & 1 & 1 & 1 & 1 & 1 & $q$ \\
\hline & иеп̣еш.res & + & & -7 & $\Xi$ & 1 & 1 & & - & 1 & 1 & - & 1 & a & - & । & - & 1 & 4 & 1 & 1 & $\exists$ \\
\hline \multirow[b]{3}{*}{ әs.он } & p!̣də⿹ & + & 1 & $1:$ & $\mathcal{I}$ & 1 & 1 & 1 & 1 & 1 & 1 & - & 1 & - & - & $\sim$ & 1 & -5 & + & $a$ & 1 & 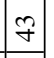 \\
\hline & иепџвшще $S$ әңв $T$ & $m$ & 1 & 19 & $m$ & 1 & 4 & & $m$ & - & $\mathrm{N}$ & $m$ & - & $\approx$ & - & 1 & a & I & $m$ & - & 1 & $\pi$ \\
\hline & ивп̣еш..еs & - & 1 & 1 & (3) & 1 & n & & - & - & 1 & $m$ & 1 & $\simeq$ & 6 & $m$ & 1 & । & $a$ & $a$ & 1 & $\pi$ \\
\hline \multirow[b]{3}{*}{$\begin{array}{r}10008 \\
\text { /dəəЧS }\end{array}$} & p̣̣də⿹ & m) & 1 & $1:$ & $\infty$ & - & 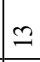 & & $m$ & 1 & 1 & 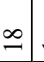 & - & m & in & $m$ & ה & 1 & $\underline{\theta}$ & if & 1 & สิ \\
\hline & 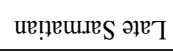 & $\infty$ & 1 & $1=$ & $=$ & 1 & - & & 1 & 1 & 1 & 1 & 1 & - & 1 & 1 & 1 & 1 & 1 & 1 & 1 & 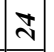 \\
\hline & ивп̣еш.res & ㄴ & 1 & & q & - & 4 & & 1 & - & - & $a$ & 1 & \pm & $\mathrm{N}$ & 1 & 1 & 1 & a & $\infty$ & 1 & 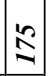 \\
\hline \multirow[b]{2}{*}{ jeog } & S!də⿹ & 1 & 1 & 1 & $\mathrm{I}$ & 1 & 1 & 1 & 1 & 1 & 1 & 1 & 1 & 1 & 1 & 1 & 1 & 1 & 1 & 1 & 1 & - \\
\hline & uв̣̣еш.res & 1 & 1 & 1 & 1 & 1 & 1 & 1 & 1 & 1 & 1 & 1 & 1 & 1 & 1 & 1 & 1 & 1 & 1 & 1 & 1 & + \\
\hline \multirow[b]{3}{*}{ dəәчS } & p̣̣də⿹ & 1 & 1 & 1 & 0 & 1 & - & & 1 & 1 & 1 & $\mathrm{a}$ & 1 & $m$ & 1 & 1 & 1 & 1 & 1 & 1 & 1 & \& \\
\hline & иепџвшще $S$ әңв $T$ & 1 & 1 & & a & 1 & 1 & 1 & 1 & 1 & 1 & 1 & 1 & & 1 & 1 & 1 & । & 1 & 1 & 1 & $\sim$ \\
\hline & иеп̣ешurs & - & । & & $\infty$ & 1 & m & - & - & 1 & $\mathrm{~N}$ & $\infty$ & 1 & $\because$ & । & 1 & 1 & । & 1 & 1 & 1 & m \\
\hline \multirow{4}{*}{ 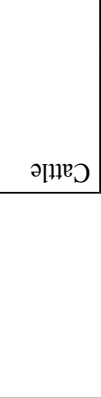 } & p̦̣də⿹ & $=$ & & & f & + & $\infty$ & & 6 & + & in & $\mathrm{a}$ & a & $\bar{m}$ & $m$ & $m$ & $m$ & $m:$ & $\approx$ & ป & - & $\stackrel{\substack{n\\
}}{2}$ \\
\hline & ивп̣ешщеs әәет & a & 1 & & 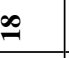 & - & in & - & 4 & N & 1 & 6 & - & 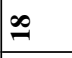 & 6 & 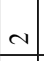 & - & -5 & $\Theta$ & $a$ & 1 & a \\
\hline & иепฺвшеге & 요 & & & ఫా & 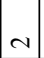 & 운 & 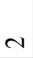 & $\infty$ & - & ـ & 2 & 1 & in & 인 & 6 & in & + & 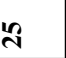 & $\underline{0}$ & 1 & $\frac{7}{m}$ \\
\hline & & 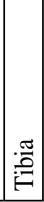 & 誩 & & 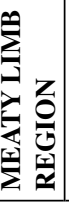 & 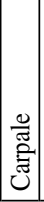 & & & 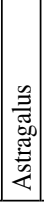 & 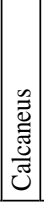 & 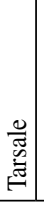 & . & 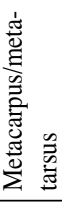 & 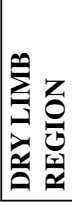 & 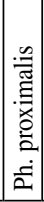 & 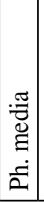 & 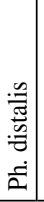 & 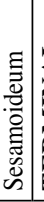 & 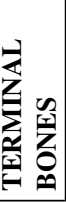 & 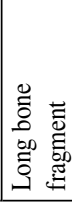 & 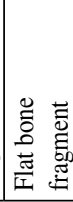 & 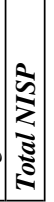 \\
\hline
\end{tabular}


71 horse bones turned up that is $8.19 \%$ of the definable Sarmatian bones. The number of individuals is between 5 and 34. Late Sarmatian objects also contained 71 horse bones, but their ratio is almost $30 \%$ in this period of time. The number of individuals is between 4 and 15. While in the Sarmatian period horse bones are the third most common bones, in the Late Sarmatian period it is the second common bone. However, in the Gepids period, all domestic meat-producing mammals were more common than horses (Table 3).

The youngest of the 5 Sarmatian horses was less than 1-year-old. Even the 2.5-3 years old animal can be considered as young as well. Two animals were mature; one of them was approximately 5 years old. The oldest animal is an approximately 15 years old mare. It was rare to keep horses until such an old age.

Based on the maximum number of individuals, one of the 34 animals was younger than 1-year-old, 2 animals were young (1-2.5 years old), 15 adults and 1 old. However, the number of non-determinable animals was large: 15 specimens.

In the lower number of Late Sarmatian bone assemblage, one of the 4 horses was almost adult, one was 5-6 years old and 2 were older. The maximum number of individuals is 15 , where 2 specimens were juveniles, one subadult, 2 adults, one was 5-6 years old and 3 specimens were older animals. The age of six individuals could not be determined, but they certainly were not young specimens.

Table 5. The withers of horse $(\mathrm{cm})$

\begin{tabular}{|l|l|l|}
\hline \multirow{2}{*}{ Bone type } & \multicolumn{2}{|c|}{ Withers (cm) } \\
\cline { 2 - 3 } & Sarmatian & Late Sarmatian \\
\hline Tibia & 134 & 144,4 \\
\hline Metacarpus & 132,5 & 129 \\
\hline Metacarpus & 133 & $131-132$ \\
\hline Metacarpus & 138,8 & - \\
\hline Metatarsus & 137 & - \\
\hline Metatarsus & 140,7 & $138-139$ \\
\hline Metatarsus & 145 & - \\
\hline
\end{tabular}

The consumption of horse meat is also indicated by cut bones: signs of cuts are seen at the cranial end of the second cervical from the Sarmatian period. Traces of cuts in the ischium of a pelvis also indicate meat consumption. On the front of a Late Sarmatian cochlea (snail shell-shaped dense bone), there are small traces of cuts. Pieces of cut Gepids horse bones have not been found, but chewed remains had. Tooth marks at the lower end of a phalanx were found suggesting that dogs living in the village had access to kitchen waste bones.

The withers of horses could only be estimated on the basis of intact long horse bones from Sarmatian and Late Sarmatian objects. Intact long bones from Gepids objects did not turn up. Horses of various sizes lived during both the Sarmatian and Late Sarmatian periods. Smaller horses were around $130 \mathrm{~cm}$ high, medium-sized horses were between 138 and $140 \mathrm{~cm}$ and the highest horses were $144-145 \mathrm{~cm}$ high. ${ }^{90}$ In the Sarmatian and Late Sarmatian period, horse bones are more frequent than pig bones. However, among meat-producing animals, ruminants are followed by pigs in the Gepids material. The number of Sarmatian and Late Sarmatian pig bones almost corresponds with each other; they are 44 and 43 pieces. There is a big difference in the proportion of bones, as while the 44 Sarmatian pig bones represent $5.07 \%$, pig bones represent $18 \%$ (Table 3) in the lower total bone number of the Late Sarmatian period.

The number of Sarmatian pig individuals is between 5 and 24. Based on the minimum number of individuals, the age of the animals are as follows: The youngest specimen is $3 / 4-1$-year-old. Two specimens are $1 \frac{1 / 4}{4}$ years old, one is 2-3 years old and one is a subadult male animal. Much of the 24 specimens were young: 13 individuals; three were subadult, one of them was male. The age of eight specimens could not be determined.

Only young specimens were found among Late Sarmatian individuals. According to the minimal number of individuals the youngest animal was slaughtered before its $1 / 2$ year old age, one animal at the age of 9 months old and one at the age of one. The two oldest pig could be only 2 years old. At this age, a pig is mature, but not yet fullgrown. The maximum number of individuals is supplemented by two specimens younger than 1 year-old and 2 specimens of undetermined age.

${ }^{90}$ KIESEWALTER 1888; VitT 1952. 
The withers of 1-1 individuals could be determined in both of the periods, the Sarmatian pig was a $70 \mathrm{~cm}$, the Late Sarmatian was a $72 \mathrm{~cm}^{91}$ short animal.

94 pig bones account for $9.9 \%$ of the findings. Regarding the number of individuals, the lowest number is 8 , the highest is 18 . Compared to the amount of bones, this number is very significant, as it approximates the number of small ruminants and cattle. The age distribution of individuals is mixed. In the case of pigs, it is common that very young animal remains appear in the findings, as they are short-lived, fast-growing animals that have more piglets at the same time, making it easy to replace slaughtered animals. Comparing to other domestic species pigs are meat producing animals, there are no other forms of utilization.

Based on the smallest number of individuals, one pig was only $1 / 2$ years old and one was $3 / 4$ years old when it was slaughtered. A one-year-old animal can be considered as young as well. There were a few specimens that could not be precisely defined: one 2-3 years old, a younger than 2.5 years old, one 2.5-3.5 years old and 2 adult pig, including a male animal.

The number of individuals per object (the maximum number of individuals) was as follows. It added 10 animals to the above mentioned: the number of juvenile pigs (less than 2.5 years old) was not one, but 4, 2 individuals were 2.5-3.5 years old and 3 individuals (instead of 2) were adult. The age of 5 animals could not be defined. The majority of pig bones are derived from the head region in all of the periods (Table 4). This means that the meat of the head and face were popular.

On the basis of charcoal analysis, hardwood gallery forest existed in the vicinity of the settlement, mostly with oak trees. Oak acorn served as the basis for pig feeding. In October and November pigs ate fallen acorns up in the forest, while in the case of early snowfall they ate the rest of the acorns during spring.

Both Sarmatian and Late Sarmatian findings contain 1-1 hen bone, a raven toe and a humerus. Both bones derived from undamaged, mature specimens. Usually, poultry bones are very rare or are missing in Sarmatian findings. Only a few bird bones turned up in Dunavecse-Ugordáció I. site, in both the level of the $2^{\text {nd }}$ and $3^{\text {rd }}$ century and the Late Sarmatian $\left(4^{\text {th }}-5^{\text {th }}\right.$ century) level. Two pieces of bird bones, probably domesticated poultry bones were found in the level of the $2^{\text {nd }}$ and $3^{\text {rd }}$ century. ${ }^{92}$ The same could be observed in the Orosháza-Községporta-Szücs-tanya site, where only 2 of the 375 pieces of bones proved to be hen bones. Goose bones are completely missing. ${ }^{93} \mathrm{Al}-$ though, the number of chicken bones ( 38 pieces) was behind horse bones (43 pieces), using the number of individuals' calculations (4/11) it preceded the number of horse individuals (3/9). The volume of meat obtained by the slaughtering of animals is not even approaching to that of horses, not either small ruminants and pigs. The minimum number of individuals was at least 4, maximum 11. Based on the minimum number of individuals, 2 specimens were not yet mature and there were 2 adults, including one male and one female. Based on the number of individuals per object (maximum number), 11 specimens could be identified, of which 4 were non-mature, 7 were adults including 3 females and one male.

Goose bones are known from every time period of the site. There are two goose bones in the Sarmatian and one in the Late Sarmatian material. Most of the bones were found in the Gepids level, where 8 related bones of a goose-like bird turned up from the object 194 (a building). The number of individuals was two in the Sarmatian period, and one-one in the Late Sarmatian and Gepids era. Each bird was an adult specimen.

The 166 pieces of Sarmatian dog bones derive from a surprising number of individuals even in case of the minimum number of individuals. Out of the 11 specimens, only two was young, one of them was younger than 1 year old, the other was young, almost adult. The rest of the animals are adult specimens; five of them died at an older age. There is a vertical mark of cut on the left jawbone, on the outside of the bone between the $\mathrm{P}_{3-4}$ (Fig. 24) of an adult but not old dog. According to this finding the slaughter of dogs and the consumption of their meat do not seem to have ended in the Celtic Period. Earlier, Hungarian archaeozoology supposed that people stopped eating dog meat after the Bronze Age. ${ }^{94}$ However, recent research has shown that neither Scythians nor Celts rejected dog meat. This Sarmatian jawbone proves that the consumption of dog meat occurred during the Roman Age as well.

In this site, the number of dog bones was less than that of a single complete animal, yet the number of individuals is quite high. Most bones were parts of the head, including the skull, chin and jawbone. One-one skulls

\footnotetext{
${ }^{91}$ TEICHERT 1969

${ }^{92}$ TugYa-Lichtenstein 2014, 146.
}

\footnotetext{
${ }^{93}$ TUGYA-RÓZSA 2012, 226, Fig. 1.

${ }^{94}$ VÖRÖs 1996, 210; VÖRÖs 1999, 293.
} 


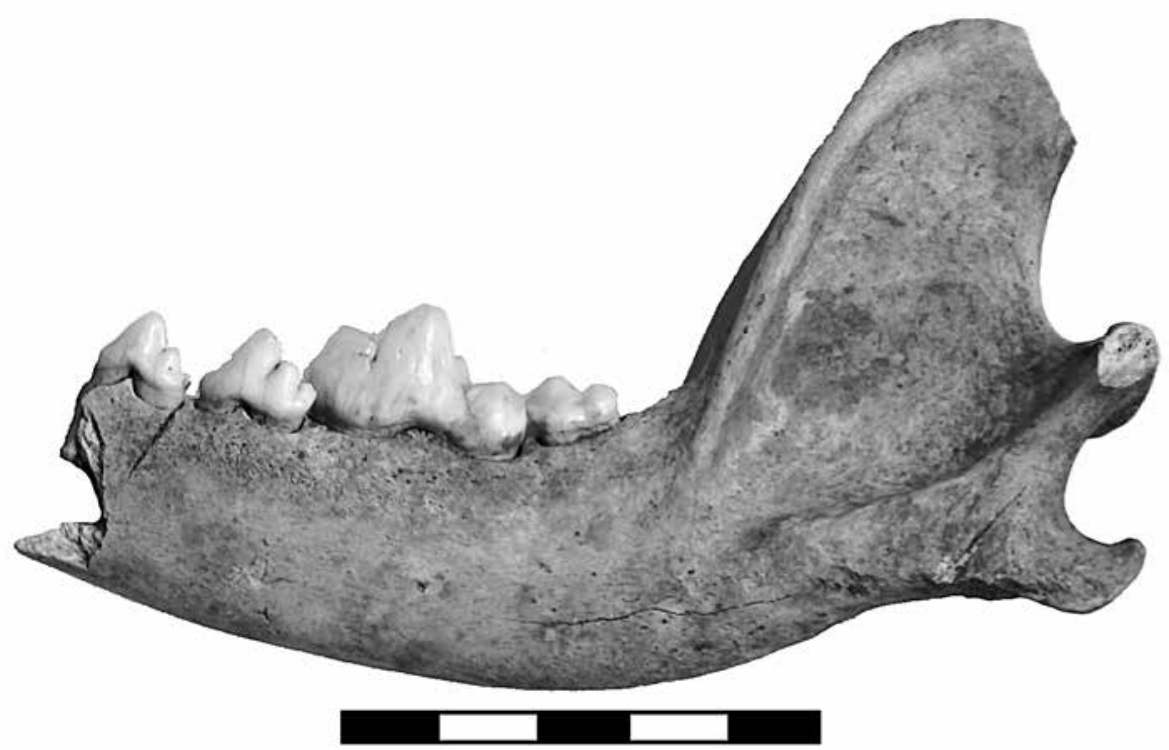

Fig. 24. Sarmatian dog jaw, with cutting mark between $\mathrm{P}_{3-4}$

without limbs turned up in four objects and only one-one jawbone was found in two objects. For example, in object 339 only the dorsal-lumbar part of the spine was exposed.

Dogs can be divided into three height groups: the smallest are $40-41 \mathrm{~cm}$ in height, such as puli dogs nowadays. Medium-sized ones are 48-51 cm and the largest are $62-65 \mathrm{~cm}$, for example, shepherd dogs (such as today's German shepherd) or hunting dogs (such as the male Hungarian vizsla).

A bone coalition can be seen on the back leg of an older dog due to an inflammation process of the metacarpus and metatarsus on the foreleg and back leg of the animal (Object 255, Fig. 25).

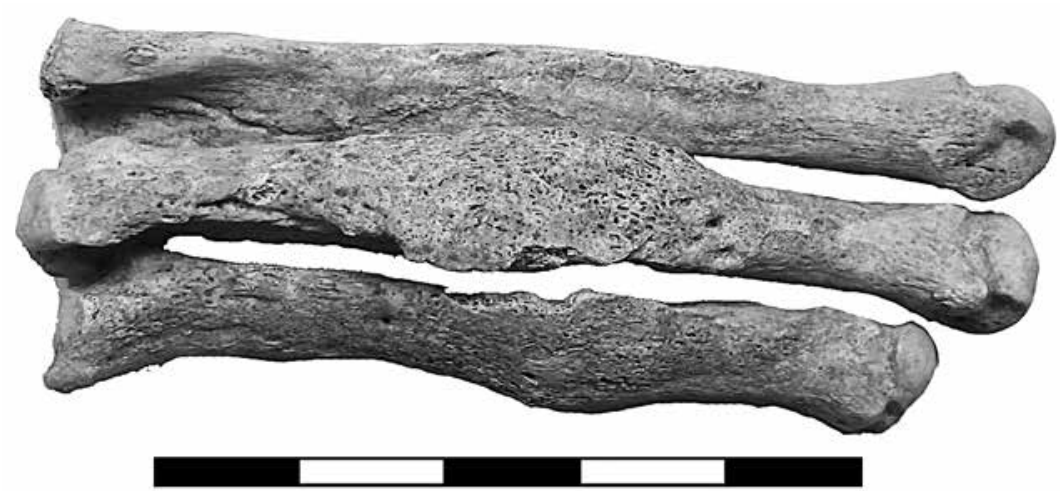

Fig. 25. Inflammation process of metatarsus of an older sarmatian dog

Dog bones from the Late Sarmatian period have also been found, however only two pieces: a jawbone and a femur fragment of an adult animal or animals.

In the Gepids period, the 108 dog bones refer to five animals. The minimum and maximum number of individuals corresponds with each other. One of the dogs is new-born, one of them is a puppy, one of them is young and two of them are adults.

The withers can be calculated on the basis of the long bones of one of the adult dogs. The very short, dense bones indicate a 24-29 cm high, slightly bandy-legged dog. ${ }^{95}$ Such small dogs are very rare during this period of

\footnotetext{
${ }^{95}$ KOUDELKA 1885.
} 
time; they can be observed only in the Roman Age. This animal can be classified as a small dog, weighing between 4.5 and $11.5 \mathrm{~kg}$. Dachshunds have such parameters today.

43 pieces of the Sarmatian bones were chewed by dogs, that is $5 \%$ of the bones. 12 bones of the Late Sarmatian period are chewed that is also $5 \%$ of the bones. In the Gepids assemblage, 16 bones are chewed (1.5\%) including cattle, small ruminants, pig and hen bones. It is not even possible to estimate the number of bones that have been completely consumed. The cartilage bone ends of young poultry, especially hens, could be easily consumed by cats or even by humans that increase taphonomic loss.

In the Sarmatian period, 32 cat bones turned up in three objects. None of the animals was adult. Three bones of one cat turned up, a humerus and two tibias. Another cat's back limb (pelvic, femur ad tibia) and forelegs, including a humerus, a cubit bone and a rib fragment subsisted. The remain of the third cat is the most complete: 15 bones were found including the fragments of the skull and chin bone, two lumbar vertebrae bones, its scapula, left humerus, radial bone and cubit bone (forelegs), its left pelvic, left and right femur and tibia (back legs) and its right fibula.

The role of cats could be to keep rodents away in the vicinity of houses and crop storage pits.

Only one red deer bone was found, from a Sarmatian pit, a $14 \mathrm{~cm}$ long metacarpus bone of an adult animal. This leg bone does not contain any substantive meat. Its occurrence suggests that the animal was completely transported to the settlement, and the valueless parts of the animal were not left behind in the hunting site. Deer or other big games were not found in the Late Sarmatian and Gepids finds.

Fish bones can be found in all of the examined time periods, which proves fishing and the extensive use of the alluvial plain. Several species were found in the Tisza bed, in the backwaters and in the floodwaters: the larger catfish (Fig. 26), the smaller pike (Fig. 27) and other smaller fishes. There are 11 fish bones in the Sarmatian part of the manual collection, only 2 in the Late Sarmatian and 44 in the Gepids fish bone assemblage. The sifting of the filling of objects would have multiplied the quantity of fish bones.

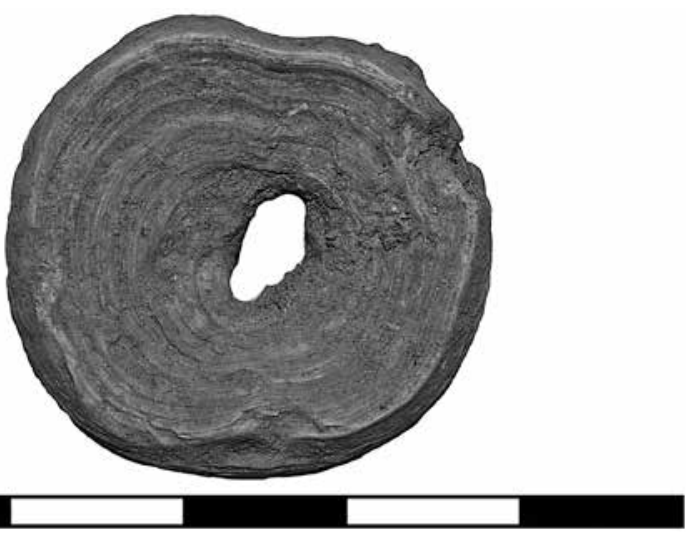

Fig. 26. Catfish vertebra from Gepid object

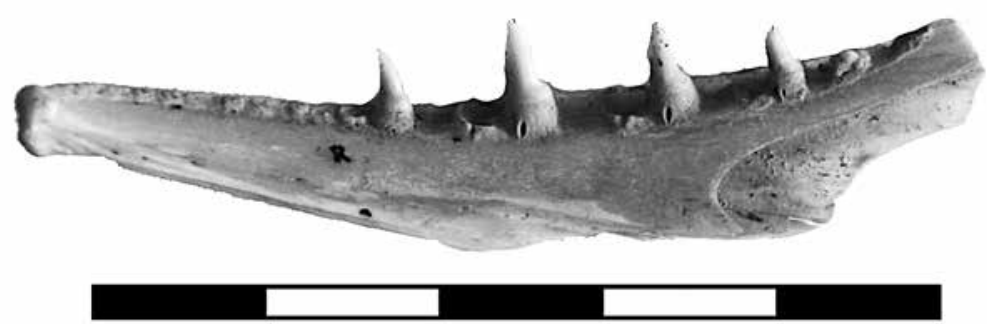

Fig. 27. Sarmatian pike jaw

The catfish is common in rivers and lakes while the pike favor lakes and oxbows with fresh water income and rich vegetation. The catfish is a large fish; its meat is delicious, fat-rich, and bone-free. The advantage of the pike is that it does not pit in winter, so it can be fished from a leak; its meat is white, clean, tasty, but has bones. The quality of the meat is influenced by the purity of the water, and the taste of small fishes ate up by the pike. 
The minimum individual number of fish bones is three in the Sarmatian period, one in the Late Sarmatian and 4 in the Gepids era. The maximum individual number chronologically is six, two and nine. The pectoral spine of a catfish found in a Sarmatian object derives from a much smaller fish than those bones that derive from Copper Age and Avar objects of the site.

The smaller amount of fish bones and mammal bones are very important because they prove that meat consumption of a community was much more colourful and was not limited to domestic animals.

The shell remains of the European pond turtle were also discovered in the Sarmatian, Late Sarmatian and Gepids period. Their number is low, only 1-2 fragments turned up. This turtle species - that is the only one native turtle species in the Carpathian Basin - favour shallow, muddy stagnant water that could be found in the vicinity of Rákóczifalva as well. As a reptile, it favours sunny places, dense forest lakes and oxbows with gallery forest. Only turtle shell fragments occurred in the findings, which refers to the consumption of turtle meat. If bones are found along with the shell remains, it can be the remains of an animal that died during winter. By the way, its meat is edible; old Hungarian cookbooks contain recipes on how to prepare it.

\section{Bone artefacts}

The bone material contained a total of 16 bone tools, including awl from bone, chisels, an unfinished skate made from bone, abrasive bone, and bone anvils. Most bone tools ( 8 pieces) come from Sarmatian objects, 6 from the Late Sarmatian and 2 from the Gepids period. Awl from bone and chisels turned up in Sarmatian and Late Sarmatian objects, abrasive bones were found in Gepids objects as well. The bone skate was Sarmatian. Bone anvils turned up only in Late Sarmatian and Gepids material.

Three awls from bone, one scraper, and a bone tool with a broken end occurred. Unfortunately, it was not possible to decide which of the two bone tools the latter was. Two Sarmatian bone awls were made of dog bones, both fragments were elbow bone, one of them was 7.4 and the other was $9.1 \mathrm{~cm}$ long. In the Avar Age, a common bone tool (usually awl from bone) was made from the elbow bone (ulna) of a dog. This type of tool can also be observed in the Sarmatian findings of Rákóczifalva. This bone of a dog was used in two cases as a bone awl. The findings are abraded and shiny, the spur of the elbow bone almost completely disappeared and the surface of the

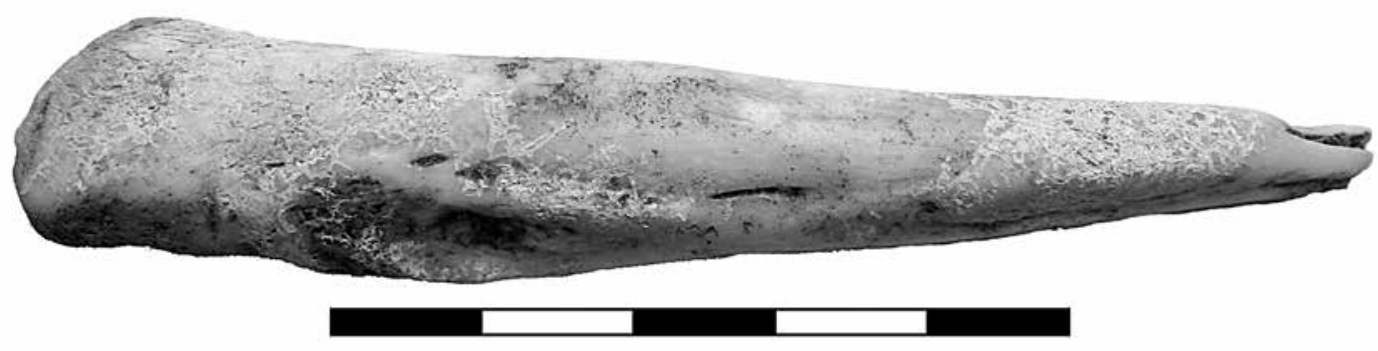

Fig. 28. Sarmatian awl from dog ulna

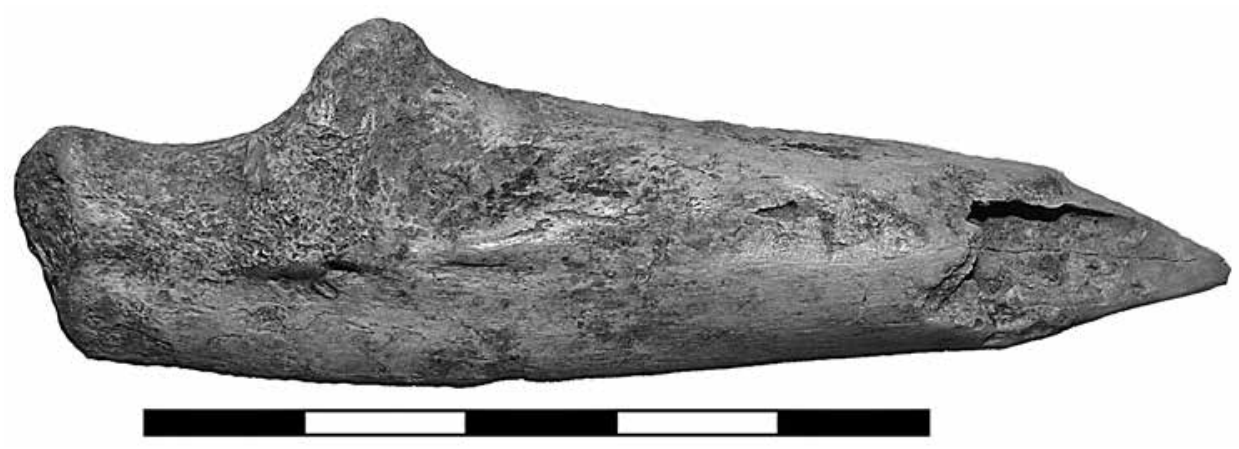

Fig. 29. Sarmatian awl from dog ulna

Acta Archaeologica Academiae Scientiarum Hungaricae 71, 2020 
finding is dotted with root marks (Object 263/388, Fig. 28). The other awl from bone is shiny as well and the spur of the elbow bone is clearly visible (Object 905/1349, Fig. 29). When a dog bone is used as a tool, it is suspected that even the dog's meat may have been eaten, although further research was not conducted in this direction.

The third awl from bone was Late Sarmatian, the diaphysis of a cattle's tibia, longer than the previous bone awl with it's $11.3 \mathrm{~cm}$ length (Fig. 30). The outer edge of the distal side was turned into an awl from a bone-like tool; its surface was abraded and shiny. The bone chisel (Sarmatian) was made from the diaphysis of a sheep/goat tibia. It was $7.5 \mathrm{~cm}$ long, one of its ends was carved, shiny and abraded (Fig. 31). There are two drilled holes at the lower end of a diaphysis of a sheep/goat tibia; the bone was broken at one of the holes. The other end of the object was turned into an awl from bone or a scraper. It is $11.3 \mathrm{~cm}$ long and comes from a Sarmatian object (Fig. 32).

Abrasive bones occurred in all of the three periods, 4 were found in Sarmatian object and one-one in Late Sarmatian and Gepids object. Abrasive bones are tools used for the thinning, smoothing and refining of surfaces. ${ }^{96}$ Most often, the leg bones of large ungulates (cattle, horses) were used for this work. Usually, the sides are abraded, but the traces of it are mostly tangential rather than longitudinal, the bones are larger, even full bones can be abrasive bones. The traces of abrasion can be seen in the backside of a $10.8 \mathrm{~cm}$ long piece of a metatarsal bone of a cattle

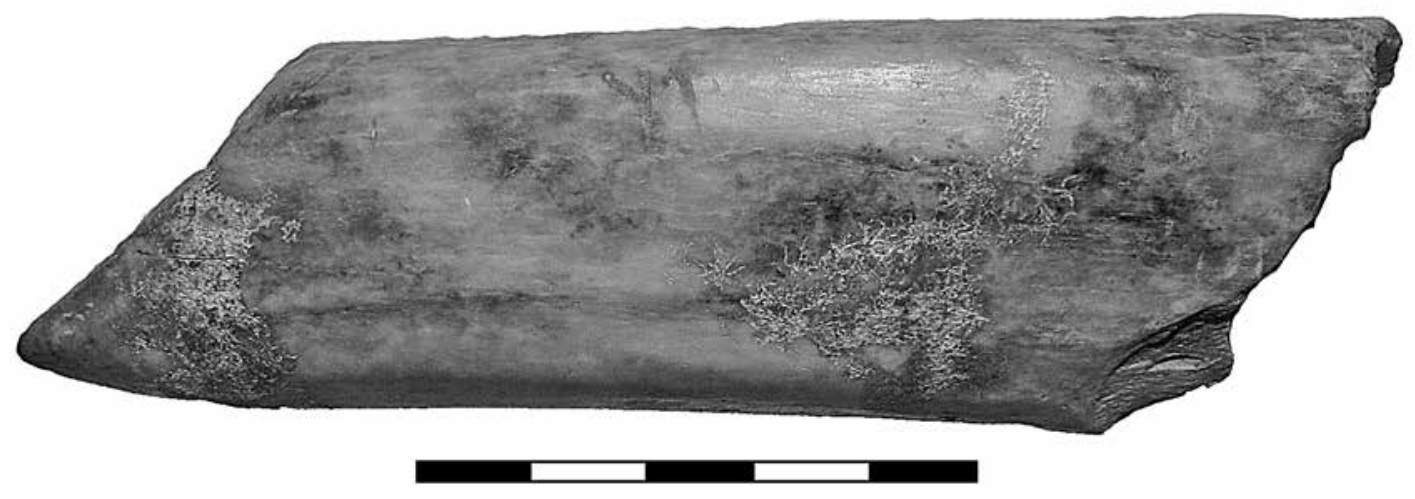

Fig. 30. Late Sarmatian awl from cattle tibia

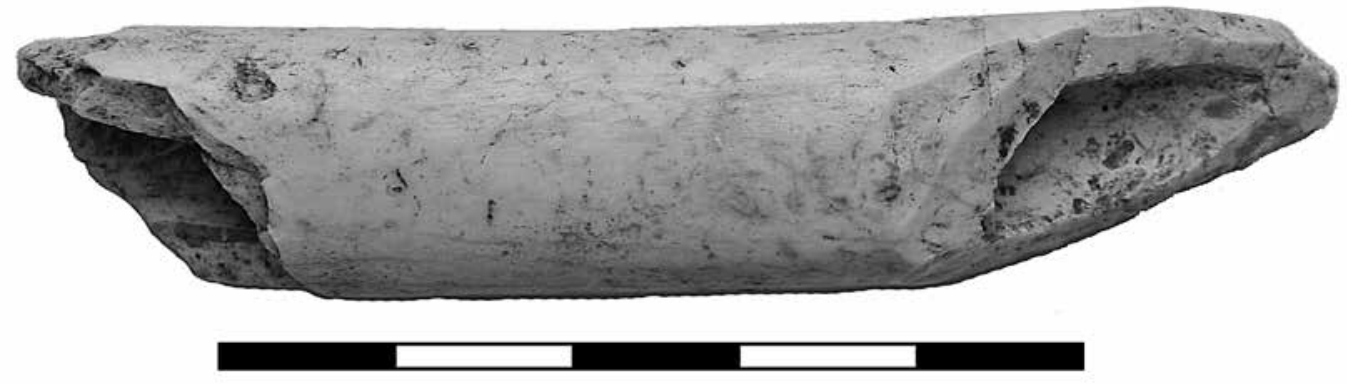

Fig. 31. Late Sarmatian chisel from sheep/goat tibia

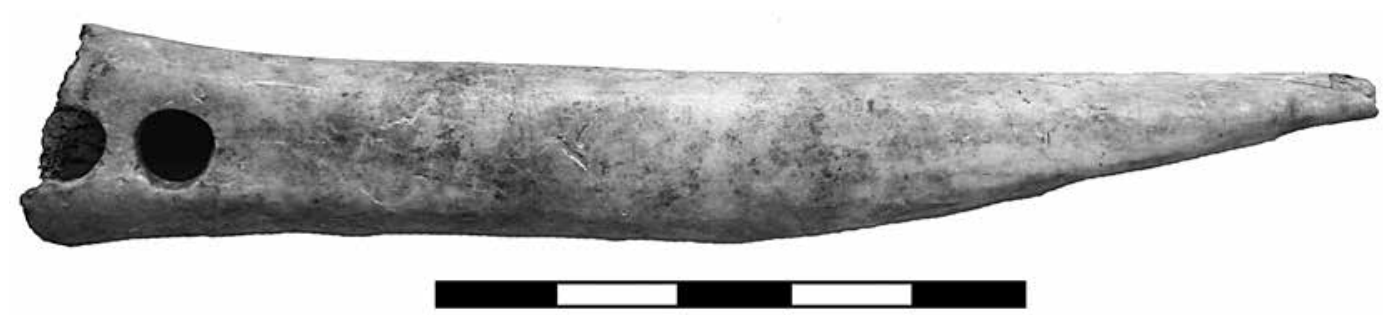

Fig. 32. Sarmatian bone tool from sheep/goat tibia

${ }^{96}$ KÖRÖSI 2010, 104. 


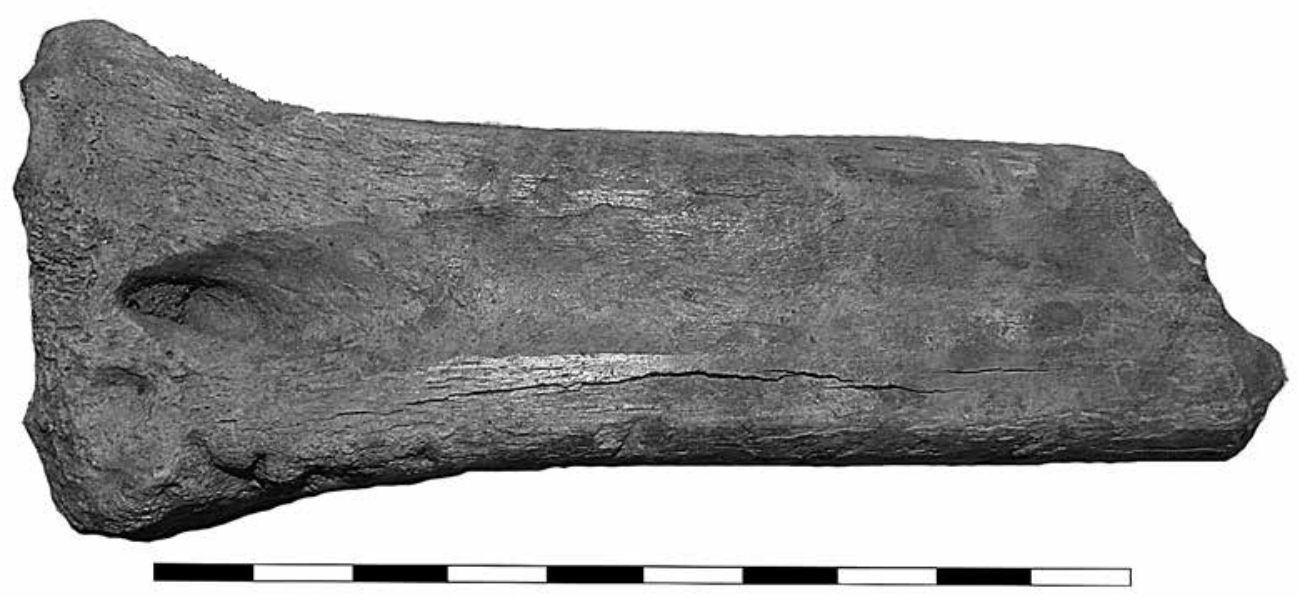

Fig. 33. Sarmatian cattle metatarsus with weathered surface

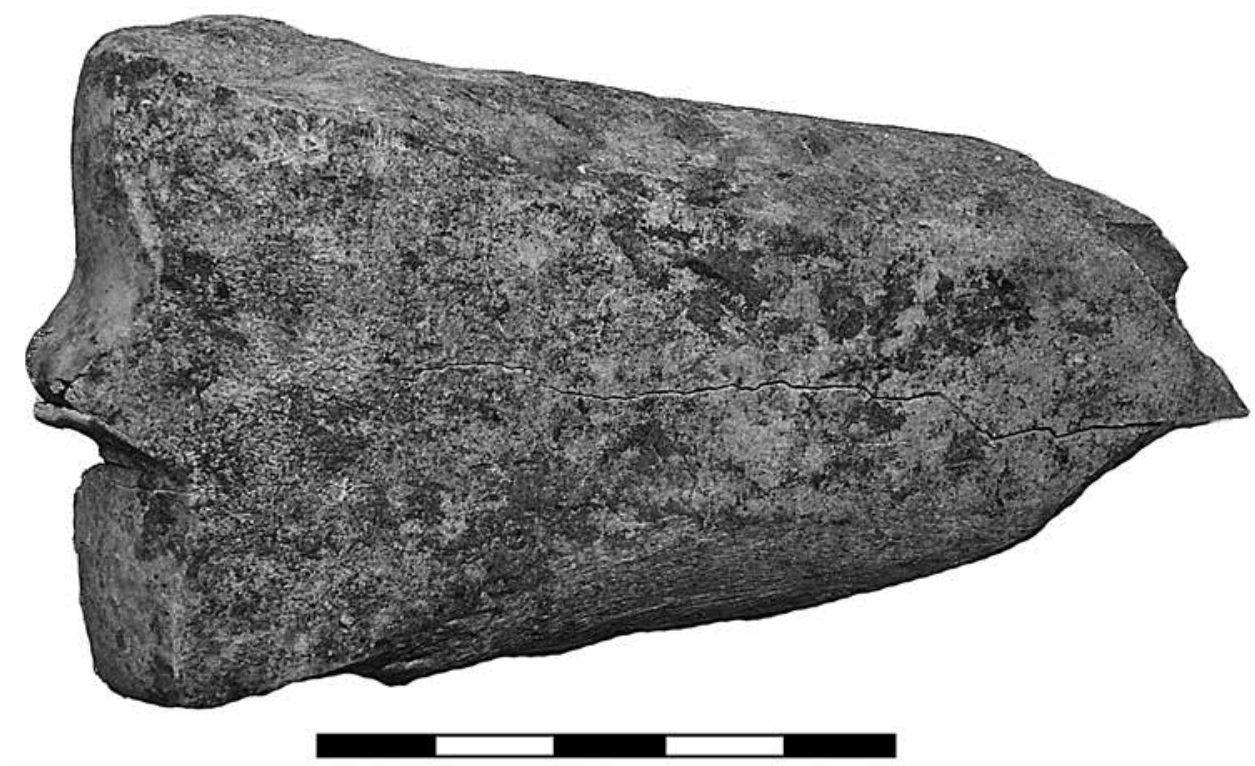

Fig. 34. Sarmatian horse metacarpus with weathered surface

(Fig. 33). From the same object (Object 273), the lower end of a $9.3 \mathrm{~cm}$ long metacarpus bone of a horse was found. The front of this bone shows signs of abrasion (Fig. 34).

Two radial bones were also found in Sarmatian objects, one cattle and one horse bone that was $15.4 \mathrm{~cm}$ and $22.2 \mathrm{~cm}$ long, with traces of abrasion on the front (Figs 35-36). From a Late Sarmatian object, an undamaged metatarsal bone of a horse was found that was $22.6 \mathrm{~cm}$ and was abraded on the front (Fig. 37).

The Gepids abrasive bone was the diaphysis of a cattle's metatarsus and was $15.2 \mathrm{~cm}$ long, with traces of abrasion on the back, and its lower end was chewed (Fig. 38). Traces of use show no difference in the Sarmatian and Gepids material.

A whole metacarpus bone of a horse was found in a Sarmatian object which can be considered as a semifinished bone skate. The ends of the bone were roughly carved, but the diaphysis was not abraded. The length of the object was $21.3 \mathrm{~cm}$ (Fig. 39).

Awls from bone, scrapers, abrasive bones and bone skates are well known during the Sarmatian period, but little is known about the bones and tools used by the Gepids. However, based on the above, there is no difference in the use of bones in the Sarmatian, Late Sarmatian, and Gepids material. 


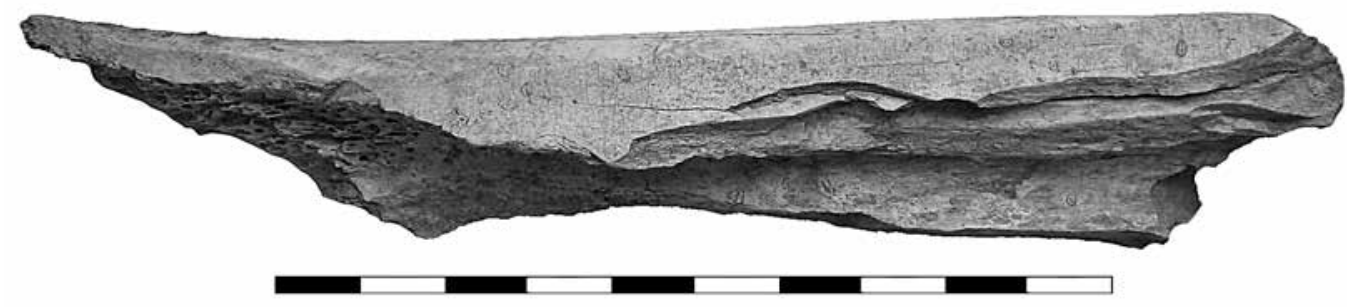

Fig. 35. Sarmatian cattle radius with sign of wear on the dorsal side

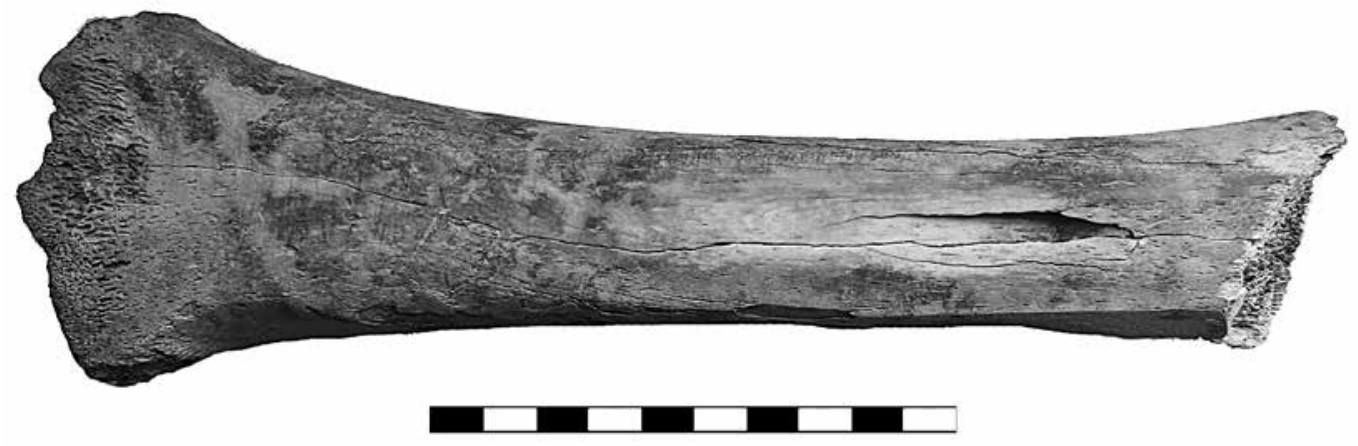

Fig. 36. Sarmatian horse radius sign of wear on the surface

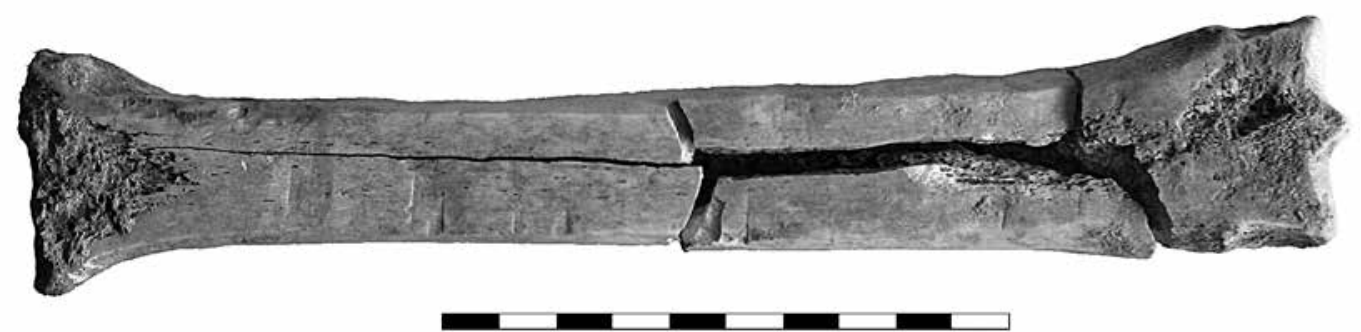

Fig. 37. Sarmatian horse metatarsus with sign of wear
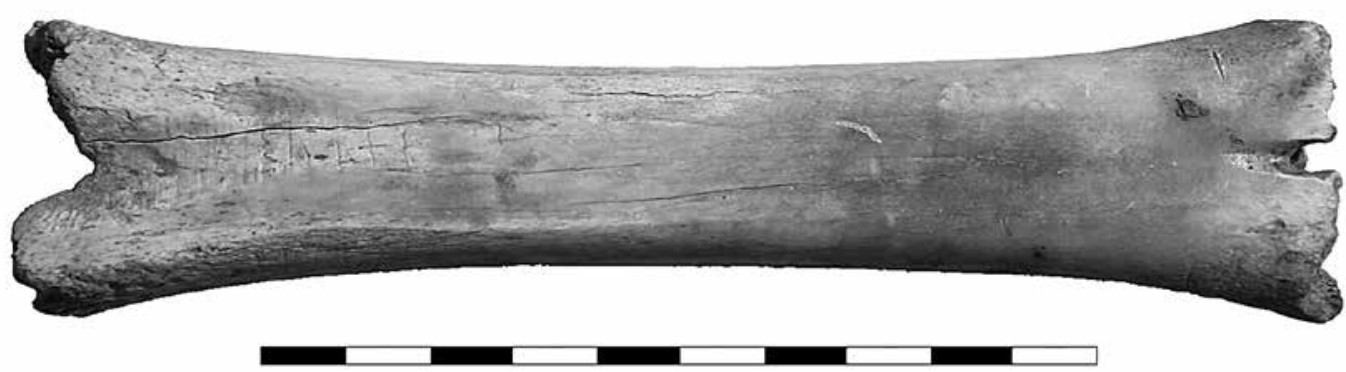

Fig. 38. Gepid cattle metatarsus with sign of wear on the plantar side

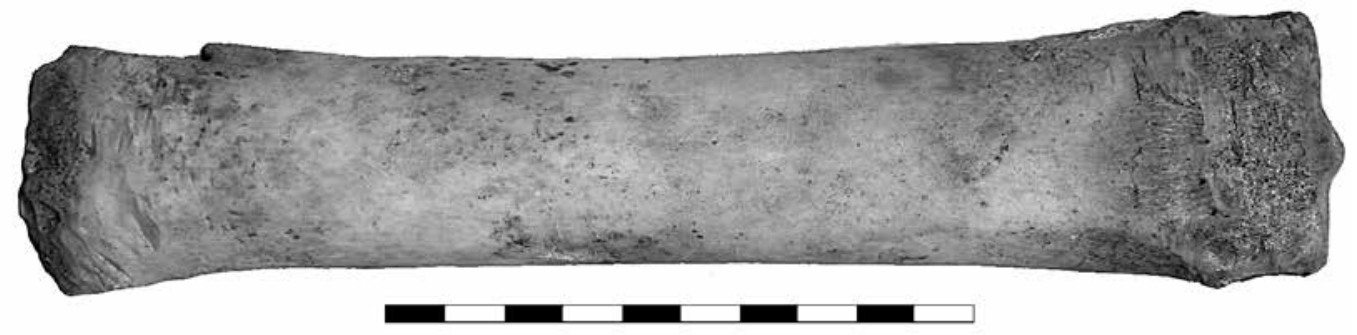

Fig. 39. Sarmatian semi-finished skate from horse metacarpus

Acta Archaeologica Academiae Scientiarum Hungaricae 71, 2020 
Four special bone objects have been found which were bone anvils; three from Late Sarmatian and one from Gepids. Their length is between 16 and $25 \mathrm{~cm}$. In the Late Sarmatian period, in two cases the jawbone of a horse (Figs. 40, 41) and in one case the jawbone of a cattle (Fig. 42) were used as a bone anvil. The Gepids bone anvil is made of a horse jawbone (Fig. 43). The bone anvil was used when the sickle teeth were repaired or recovered, or when the broken teeth of a metal anvil were replaced by a bone anvil. They were used as pads. They took advantage of the characteristics of the bones, which was their relatively large flat surface. Both sides of the jawbone have the signs of the sickle teeth, usually in several rows.

The tool has been known since the Greek and Roman times in the Mediterranean, but in the case of Hungary, the earliest bone anvil derives from the Avar period. From the site of Felgyö-Kettőshalmi-dülö 7 bones used as bone anvils were found, made from cattle and sheep bones. Interestingly, not the flat, wide jawbones were used, but long bones. ${ }^{97}$

The earliest known bone anvils derive from Rákóczifalva, not only from the Gepids period, but also earlier, from the Late Sarmatian era, from the $4^{\text {th }}-5^{\text {th }}$ centuries. Their significance in every period lies in the fact that they

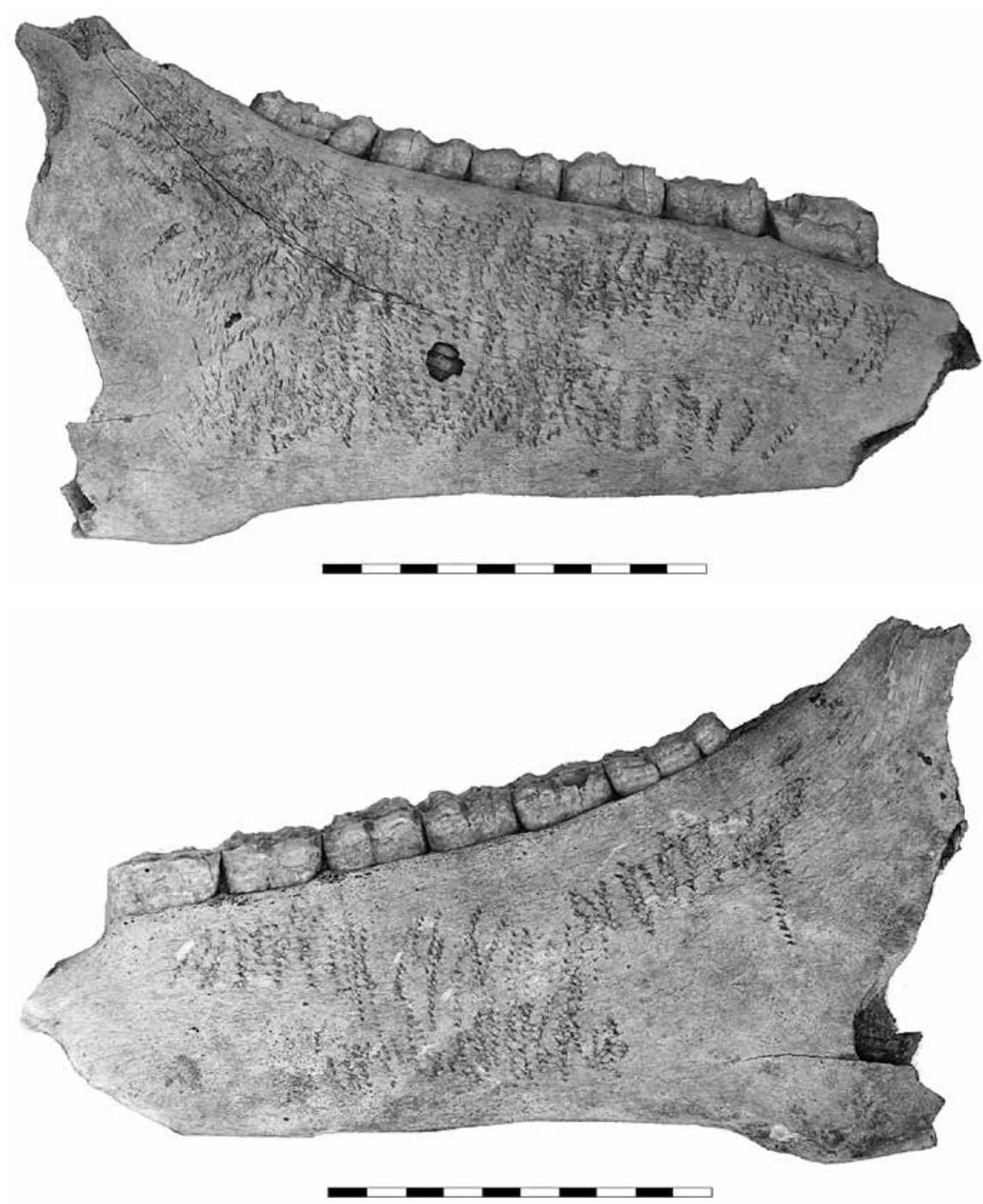

Fig. 40. 1-2: Late Sarmatian bone anvil from horse jaw (both side)

\footnotetext{
${ }^{97}$ KŐRÖSI 2010, 112.
}

${ }^{98}$ TugYa 2015, 21-27. 

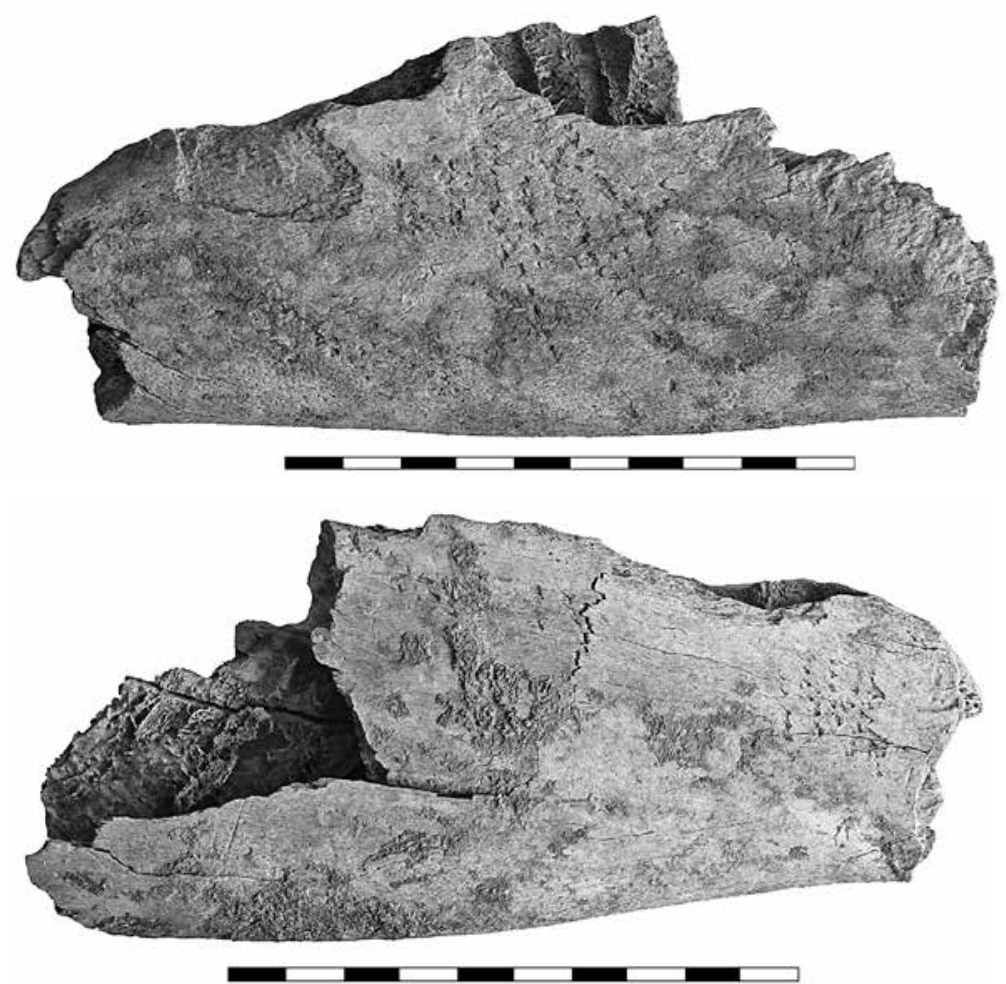

Fig. 41. 1-2: Late Sarmatian bone anvil from horse jaw (both side)
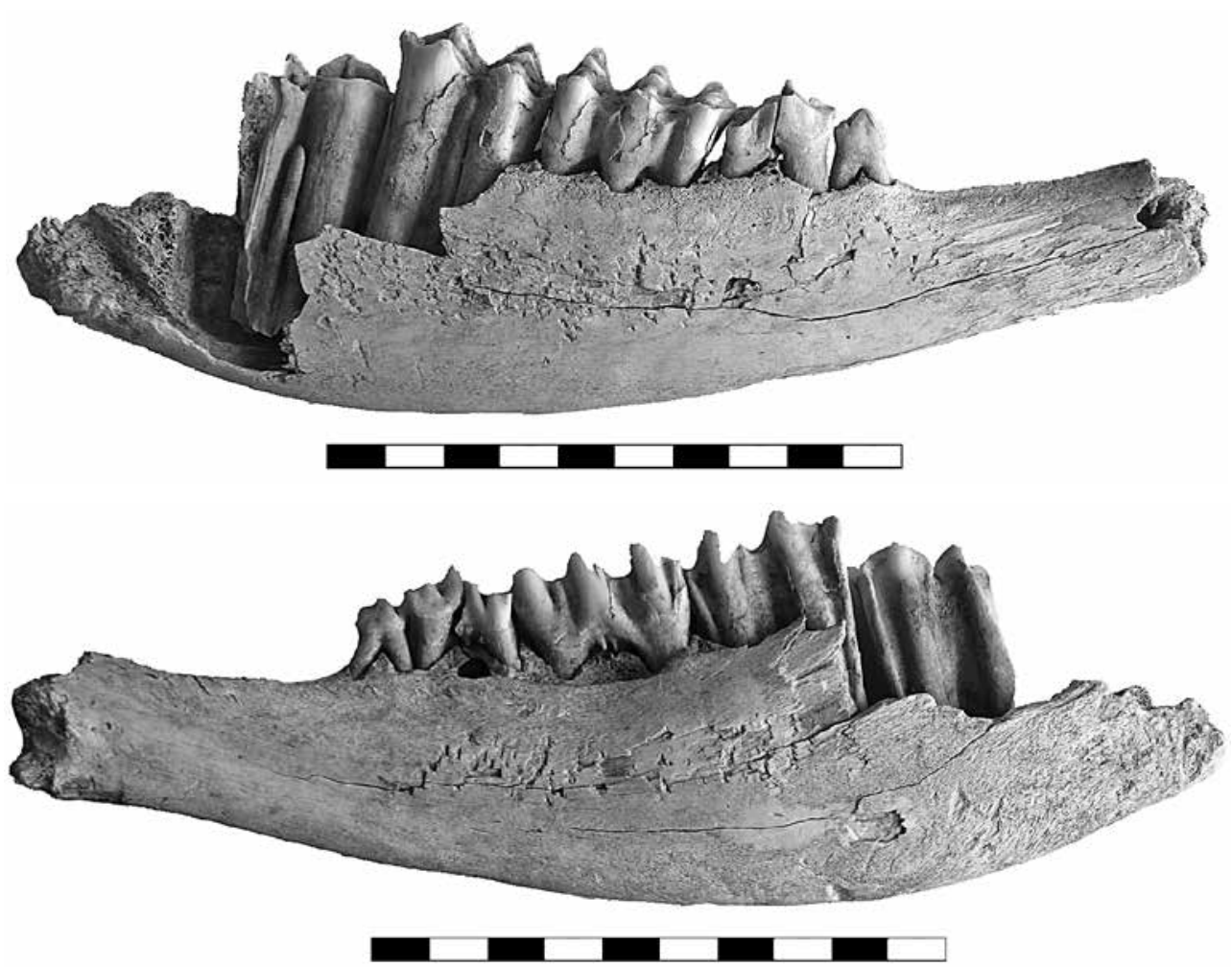

Fig. 42. 1-2: Late Sarmatian bone anvil from cattle jaw (both side)

Acta Archaeologica Academiae Scientiarum Hungaricae 71, 2020 


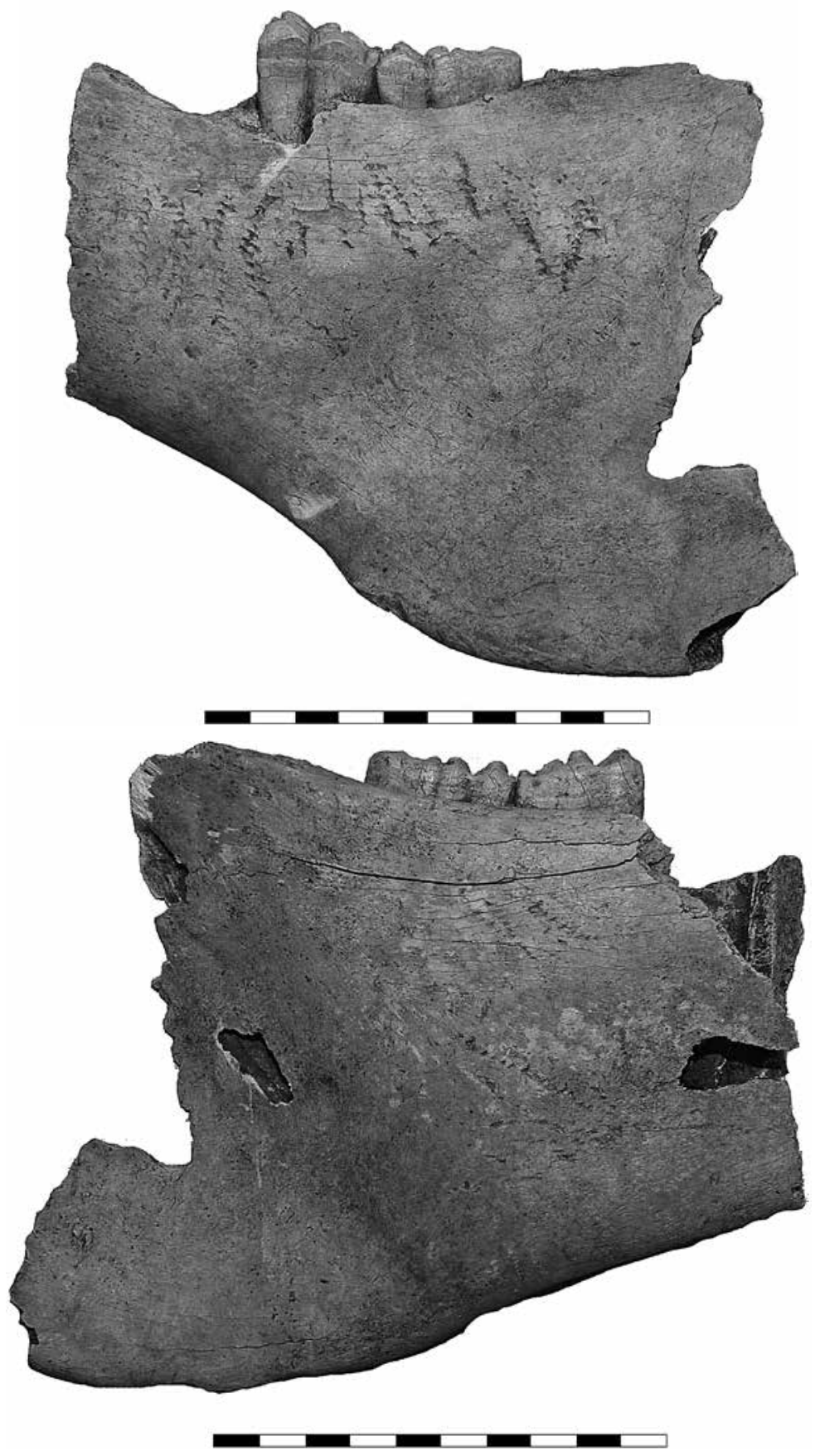

Fig. 43. 1-2: Gepid bone anvil from horse jaw (both side) 
carry information on animal husbandry and bone processing, they refer to cereals cultivation and gives evidence that the settlement had (a) forge(s) where the metal tools were maintained as well. ${ }^{98}$

Table 6: Summary table of bone tools

\begin{tabular}{|c|c|c|c|c|c|}
\hline OBNr./SNr. & Period & Species & Bone type & Length $(\mathrm{mm})$ & Tool type \\
\hline $857 / 1296$. & Sarmatian & sheep/goat & Tibia diaphysis & 113 & Awl or scraber with drilled holes \\
\hline $263 / 388$ & Sarmatian & $\operatorname{dog}$ & Ulna fragment & 91 & Awl \\
\hline 905/1349. & Sarmatian & $\operatorname{dog}$ & Ulna fragment & 74 & Awl \\
\hline $254 / 379$ & Late Sarmatian & cattle & Tibia diaphysis & 113 & Awl \\
\hline $538 / 713$. & Late Sarmatian & sheep/goat & Tibia diaphysis & 75 & Scraber \\
\hline $273 / 398$ & Sarmatian & cattle & Metatarsus prox.epiphysis and diaphysis & 108 & Abrasive bone \\
\hline $273 / 398$ & Sarmatian & horse & Metacarpus (III.) dist.epiphysis and diaphysis & 93 & Abrasive bone \\
\hline $284 / 348$ & Sarmatian & cattle & Radius diaphysis & 154 & Abrasive bone \\
\hline $302 / 368$ & Sarmatian & horse & Radius diaphysis & 222 & Abrasive bone \\
\hline $274 / 399$. & Late Sarmatian & horse & Metatarsus (whole) & 226 & Abrasive bone \\
\hline $69 / 411$. & Gepid & cattle & Metatarsus diaphysis & 152 & Abrasive bone \\
\hline $191 / 247$ & Sarmatian & horse & Metacarpus (III.) (whole) & 213 & Bone skate (semi-finished) \\
\hline $274 / 399$. & Late Sarmatian & horse & Mandibula (pars molaris) & 163 & Anvil \\
\hline $278 / 403$. & Late Sarmatian & horse & Mandibula +dentes & 250 & Anvil \\
\hline $274 / 399$ & Late Sarmatian & cattle & Mandibula+dentes & 202 & Anvil \\
\hline $365 / 464$. & Gepid & horse & Mandibula+dentes & 172 & Anvil \\
\hline
\end{tabular}

SUMMARY

Geoarchaeological, archaeobotanical and archaeozoological analysis have been carried out in the central, one of the hottest parts of the Great Hungarian Plain, in the Tisza valley, where Sarmatian and Gepids settlement and its surroundings were excavated. Based on the results of the digital relief model, maps, historical maps and geoarchaeological analysis of geological drillings, the Bagi-földek are located on a deeper and younger alluvial surface with a good water supply and are connected to the development of the Tisza River. In comparison, the Rokkant-földek is located on an older residual surface and are rising above the alluvium. The Sarmatian and Gepids communities settled on a point bar series located on the high-floodplain and low floodplain in a semi-circular, semipeninsula-like protected area. These surfaces provided different farming possibilities for the Gepids communities of the Migration Period: the utilization of the gallery forest, gatherings in the area of the forests and floodplain, fishing and hunting, extensive animal husbandry on the higher, drier areas and plant cultivation around the settlements and houses. This is supported by the archaeozoological material.

Based on the composition of domestic animals, extensive pastures, including saline pastures favourable for sheep surrounded the Sarmatian, Late Sarmatian and Gepids settlement during the $3^{\text {rd }}-6^{\text {th }}$ centuries. The area of wet meadows was outstanding due to the high number of cattle and horses as well.

Poultry keeping was not characteristic in the Sarmatian period but provided a greater source of meat and eggs in the Gepids period. Hunting was not typical any periods; however, fishing was observable, taking advantage of the opportunities provided by the Tisza River and its floodplain areas. The aquatic pond turtle could also provide meat. Shells were collected and could be consumed seasonally. Hunting did not provide a significant source of meat during the Sarmatian period, and in several Sarmatian sites bones of hunted species did not turn up. For example, in Orosháza-Községporta-Szücs-tanya site not only the bones of hunted species are missing, but fish bones as well. ${ }^{99}$ There is only one red deer bone in the Sarmatian material of Rákóczifalva. In contrast, not only red deer finds, but also remains of roe deer, wild boar and hare were found in the site of Hajúnánás-Fürjhalom-dülő. In addition to rodents, several birds and some fish bones have also been found. ${ }^{100}$ Bone tools are known from the Sarmatian period (awl from bone, scraper, abrasive bone, and skates), but the presence of bone anvils is a real curiosity in the Late Sarmatian and Gepids material. 
Based on the bone composition of the domestic animals, the area was surrounded by extensive grazing fields, including saline pastures favourable to sheep. However, the area of wet meadows and meadows was also outstandingly indicated by the high ratio of cattle and horse bones in the $6^{\text {th }}$ century, during the Gepids settling. Poultry provided a significant source of meat and eggs. Hunting was not common in the Gepids community based on the archaeozoological remains, but the fishing was observable in the Tisza River and its oxbows. The pond turtle provided meat as well. Shells were collected and seasonally consumed. Bone artefacts are already known from the late Sarmatian period (punch tool, chisels, rubbed bone and skates) in the Great Hungarian Plain, but the presence of bone anvil in the Gepids material is currently a real curiosity.

We know very little about the animal husbandry, hunting habits and meat consumption of the Gepids, so it is necessary to carry out and publish archaeozoological research of as many excavations as possible. In previous works, a farm-like Gepids settlement was discovered at the border of Battonya, ${ }^{101}$ and by the analysis of bones of some houses and pits, we found the same archaeozoological result as in the case of Rákóczifalva. The most important domestic animals were cattle, sheep and goat in both of the sites. Pigs were not significant in Battonya while in the case of Rákóczifalva, it was much more critical. Based on the number of individuals, their importance is almost the same. Dog, cat and chicken remains were also present in the Battonya site.

There is no proof of hunting in Rákóczifalva while red deer hunting was observed in Battonya. Fishing, which could supplement the amount of meat obtained from the slaughter of domestic animals, could be observed in both sites of the Great Hungarian Plain.

According to our data, the inhabitants of the excavated Gepids settlement fully utilized its Tisza valley environment for food production on an organic level in the migration period, in the $6^{\text {th }}$ century. The environment occupied by the Gepids community, the floodplain islands and residual surfaces in the Tisza Valley was inhabited from the early Neolithic. The exploitation of their environment, from settlement strategy to gathering, has a similar system as in the case of the Gepids settlement we have described. However, the ratio of unproductive farming (hunting, fishing, gathering) and productive farming (land cultivation, animal husbandry) was different in the life of these communities. At the same time, based on the composition of archaeobotanical findings and the archaeozoological material the Sarmatian communities discovered at the Rákóczifalva archaeological site were not nomadic as against to the widespread and published views. ${ }^{102}$

${ }^{101}$ SZABÓ-VÖRÖS 1979, 228.
${ }^{102}$ GyUlai 2001, GyUlai 2003, GyUlai 2010; Petỏ et al. 2017; IsTVÁNOVITS-KULCSÁR 2018. 


\section{ACKNOWLEDGEMENTS}

We express our gratitude to dr. Judit Tárnoki archaeologist for her help. We thank to Zoltán Hohl (György Thúry Museum) for the pictures of bones. The work of the University of Szeged, Interdisciplinary Excellence Centre, Institute of Geography and Earth Sciences, Long Environmental Changes research team was supported by the Ministry of Human Capacities, Hungarian grant 20391-3/2018/FEKUSTRAT.

\section{REFERENCES}

AlLEN et al. 2000

BARTOSIEWICZ-CHOYKE 2011

BÁLINT 1991

BELOKOPYTOV-BERESNEVICH 1955

BENNETT 1992

BENNETT 2005

BERGLUND-RALSKA-JASIEWICZOWA 1986 = B. E. BERGLUND-M. RALSKA-JASIEWICZOWA: Pollen analysis and pollen diagrams. In: Handbook of Holocene Palaeoecology and Palaeohydrology. Ed. B. E. Berglund. John Wiley and Sons, Chichester 1986, 455-484.

BERNÁTSKY 1914

BEUG 2004

BIRKS-GORDON1985

BIRÓ-Zs. MOLNÁR 1998

CALKIN 1960

CHAPMAN 1994

ChaPMAN 1997

CHAPMAN 2017

CHAPMAN et al. 2009

CREMASCHI 1992

CSEH 1986

= J. R. M. AlLEN-W. A. WATtS-B. HuntLey: Weichselian palynostratigraphy, palaeovegetation and palaeoenvironment: the record from Lago Grande di Monticchio, southern Italy. Quaternary International (2000) 73-74, 91-110.

$=$ L. BARTOSIEWICZ-A. M. Choyke: Sarmatian and Early Medieval animal exploitation at the Site of Endrőd 170. In: Archaeological Investigations in County Békés 1986-1992. Eds: A. Vaday, L. Kovács, B. D. Jankovich. VAH 25. Archaeological Institute of Hungarian Academy of Sciences, Budapest 2011, 285-314.

= Cs. BÁlint: Die spatawarenzeitliche Siedlung von Eperjes (Kom. Csongrád). VAH 4. Archaeological Institute of Hungarian Academy of Sciences, Budapest 1991,

= I. E. Belokopytov-V. V. Beresnevich: Giktorf's peat borers. Torfyanaya Promyshlennost 8 (1955) 9-10.

$=$ K. D. BENNETT: PSIMPOLL - A quickBasic program that generates PostScript page description of pollen diagrams. INQUA Commission for the study of the Holocene: working group on data handling methods, Newsletter 8 (1992) 11-12.

$=$ K. D. BennetT: Documentation for Psimpoll 4.25 and Pscomb 1.03: C programs for plotting pollen diagrams and analysing pollen data. Department of Earth Sciences, University of Uppsala, Uppsala 2005.

= J. BERNÁTSKY: A magyar Alföld fás növényzete [Woody vegetation of the Great Hungarian Plain]. Erdészeti Kísérletek 16 (1914) 129-180.

= H. J. BEUG: Leitfaden der Pollenbestimmung für Mitteleuropa und angrenzende Gebiete (Textbook of Pollen Identification for Central Europe and Adjacent Regions). Pfeil, München. 2004.

$=$ H. J. B. BIRKS-A. D. Gordon: Numerical Methods in Quaternary Pollen Analysis. Academic Press, London 1985.

= M. BIRÓ-Zs. MoLNÁR: A Duna-Tisza köze homokbuckásainak tájtípusai, azok kiterjedése, növényzete és tájtörténete a 18. századtól (Vegetation and land-usehistory in the sanddunes of the DunaTisza köze from the 18th century and the mapping of landscapetypes of the late 18th century). Történeti Földrajzi Füzetek 5 (1998) 1-34.

= V. I. CALKIN: Izmenčivoszty metapodii i eë značeniâ dlâ izučeniâ krupnogo rogatogo skota dvernosti [Variabilty of metapodium and their significance in the research of archeological old cattle.]. Bûl. Mosk. Obs. Ispyt. Prirody 45 (1960) 109-126.

$=\mathrm{J}$. CHAPMAN: Social power in the early farming communities of Eastern Hungary - perspectives from the Upper Tisza region. JAMÉ 36 (1994) 79-100.

= J. ChapMAn: Places as Timemarks - The Social Construction of Landscapes in Eastern Hungary. Landscapes in Flux. Colloquenda Pontica 3. Oxbow Books, Oxford 1997, 37-162.

$=\mathrm{J}$. ChAPMAN: Climatic and human impact on the environment?: A question of scale. Quaternary International 496 (2017), in press.

= J. ChapMAN-E. MagYari-B. Gaydarska: Contrasting subsistence strategies in the Early Iron Age? - new results from the Alföld Plain, Hungary, and the Thracian Plain, Bulgaria. OJA 28/2 (2009) $155-187$.

= M. CREMASCHI: Geomorphological survey and the distribution of archaeological sites. In: Cultural and Landscape Changes in South-east Hungary. I.: Reports on the Gyomaendröd Project. Ed.: S. Bökönyi. Archaeolingua 1. Archeolingua, Budapest 1992, 359-360.

= J. CSEH: Adatok Kengyel környékének 5.-6. századi települési viszonyaihoz (A gepida településkutatás történetéhez) (Data for settlement history of Kengyel village surroundings in the $5^{\text {th }}-6^{\text {th }}$ centuries AD. Data for history of the Gepids settlement research). ArchÉrt 113 (1986) 190-206. 
CSEH 1990

CSEH 1990

CSEH 1991

CSEH 1992

CSEH 1993

CSEH 1997

CSEH 1999

CSEH 1999

CSEH 1999

CSEH 2000

CSEH 2001

CSEH 2002

CSEH 2007

CSEH 2009

CSEH 2013

VON DEN DRIESCH 1976

FAEGRI-IVERSEN 1989

B. FEHÉR 2004
= J. CSEH: Adatok az V-VII. századi gepida emlékanyag egységéhez (Data for Gepids relics unit in the $5^{\text {th }}-7^{\text {th }}$ centuries AD). SzMÉ 7 (1990) 29-80.

= J. CSEH: Gepida fazekaskemence Törökszentmiklóson (Gepid potterykiln in Törökszentmiklós). ArchÉrt 117 (1990) 223-240.

= J. CSEH: Kora középkori település Rákóczifalván. Adatok a 6. századi gepida kerámia ismeretéhez (Early medieval settlement in Rákóczifalva. Data for ceramic knowledge in 6th centuries AD). MúzLev 65/66 (1991) 3-27.

= J. CSEH: Kora népvándorlás kori telepleletek Kengyel határában: adalékok a IV.-V. századi gepidák Közép-Tiszavidéki régészetéhez és történetéhez (Early migration finds from settlements in environs of Kengyel: data for Gepids history and archaeology of the Middle Tisza Region in the $5^{\text {th }}-6^{\text {th }}$ centuries AD) Szolnoki Levéltári Évkönyv (Zounuk) 7 (1992) 9-34.

= J. CsEH: Gepida településnyomok a Tisza-Morotva északi régióban: beszámoló a kengyeli 4-6. századi „Siedlungskammer” egyik pontján végzett ásatásokról (Gepid settlement prints in the northern region of Tisza-Morotva: Report for excavation at one point of Siedlungskammer in the $5^{\text {th }}-6^{\text {th }}$ centuries AD at Kengyel village). Szolnoki Levéltári Évkönyv (Zounuk) 8 (1993) 9-33.

= J. CsEH: Gepida település Rákóczifalva határában (Un site gepide près de Rakoczifalva). ComArchHung 1997, 173-194.

= J. CSEH: Üvegleletek a 4.-6. századtól Kengyel környéki településeken (Kutatás-történeti áttekintés). [Glass find from the $4^{\text {th }}-6^{\text {th }}$ centuries on setllements in environs of Kengyel (with a history of the research)] Tisicum 11 (1999) 25-30.

= J. CSEH: Régészeti adalékok egy zagyva-parti gepida településről (Falusi parasztgazdaságok a Tisza mentén az V-VI. század fordulóján) (Archaeological additives for a Gepid settlement from Zagyva riverside. Villager peasant economy from along the Tisza river in the transition of $5^{\text {th }}-6^{\text {th }}$ centuries AD). In: A gepidák - Kora középkori germán királyság az Alföldön. Gyulai katalógusok 7. Erkel Ferenc Múzeum, Gyula 1999, 39-58.

= J. CSEH: Kutatások gepida települések régészeti nyomai után Kengyel területén (1990-1995) (Researches after archaeological prints of Gepid settlement in area of Kengyel village (1990-1995)). In: A gepidák - Kora középkori germán királyság az Alföldön. Ed.: P. Havassy. Gyulai katalógusok 7. Erkel Ferenc Múzeum, Gyula 1999, 59-76.

= J. CSEH: Kora középkori gepida edények Abádszalókról (Early medieval Gepidvessels from Abádszalók). Jászkunság 46 (2000) 121-124.

= J. CsEH: A kengyeli gepida csontkorcsolya (az irongázás nyomai a Kelet-Kárpát-medence germánjainál) (Gepid boneskate from Kengyel. The marks of the use of boneskate (ironga) at the Germans of East Carpatian Basin). In: Adevărul omeneşte posibil pentru rânduirea binelui - Die menschlich mögliche Wahrheit zur Einrichtung des Guten - The Truth Humanly Possibile for the Settlement of Good. Eds: L. Cornea, M. Drecin, B. Stefanescu, A. Chiriac. Körösvidéki Múzeum kiadványa, Nagyvárad (Oradea) 2001, 279-297.

= J. CSEH: Tiszaföldvár környékének régészet emlékei az őskortól a középkorig (Függelék: a városterület gepida leletei) (Archaeological relics in environs of Tiszaföldvár from prehistoric times to the Middle Ages). In: Tiszaföldvár. Fejezetek a város történetéből. Eds: É. Kelemen, M. Pató, I. Szlankó. Tiszazugi Földrajzi Múzeum, Tiszaföldvár 2002, 33-38.

= J. CSEH: Újabb régészeti ásatás Kengyel-Kiss-tanyánál (Another archaeological excavation on Kiss farm at Kengyel). Tisicum 16 (2007) 345-375.

= J. CSEH: Kereskedelmi áru importált mázas kerámia a Kr. u. 4-6. századból kengyeli lelőhelyeken (Baghy-homok és Kengyelpart I.) (Importierte, glasierte Keramik als Handelsware aus den 4-6. Jahrhunderten in Fundstellen von Kengyel (Baghy-homok és Kengyelpart I [sic!]). Tisicum 19 (2009) 323-332.

= J. CsEH: Gepida település régészeti nyomai Kengyel-Kiss tanya mellett - 1990. Függelék: a gótgepida nyelv házra vonatkozó szavainak köréből (Archaeological prints of Gepid settlement from Kiss tanya at Kengyel - preliminary archaeological report for an excavation in 1990). Tisicum 22 (2013) 91-143.

= A. VON DEN DRIESCH: A Guide to the Measurement of Animal Bones from Archaeological Sites. As developed by the Institut für Palaeoanatomie, Domestikations forschung und Geschichte der Tiermedizin of the University of Munich. Peabody Museum bulletin 1, Peabody Museum of Archaeology und Ethnology Harvard University, Cambridge, MA 1976.

$=$ K. FAegri-J. Iversen: Textbook of Pollen Analysis. (4 ${ }^{\text {th }}$ ed. by K. Faegri, P. E. Kaland, K. Krzywinski). John Wiley and Sons, Chichester 1989.

= B. FEHÉR: Ptolemaios és forrásai - Ptolemy and its sources. In: Korai földrajzi írók - a római hódítás kora. Fontes Pannoniae antiquae. Az ókori Pannónia történetének forrásai. Ed.: B. Fehér, P. Kovács. Károli Egyetemi Kiadó, Budapest 2004, 88-105. 
FEURDEAN-WILLIS 2008

GALÁNTHA 1981

GÁL 2010

GREGUSS 1945

GREGUSS 1972

GYÖRFFY 1983

GyUlai 2001

GYULAI 2003

GYULAI 2010

GYULAI 2014

HALAVÁTS 1895

HAVASSY 1998

HORUSITZKY 1898

HORUSITZKY 1899

HORUSITZKY 1903

HORUSITZKY 1905

HORUSITZKY 1909

HORUSITZKY 1911

ISTVÁNOVITS 1999

ISTVÁNOVITS-KULCSÁR 2011

ISTVÁNOVITS-KULCSÁR 2018

IVERSEN-FÆGRI 1964

ÍRÁS 2013

JACOBSON-BRADSHAW 1981

JACOMET-KREUZ 1999

GY. JUHÁSZ 1992
= A. FEURDEAN-K. J. WILlis: Long-term variability of Abies alba in NW Romania. Diversity and Distributions 14/6 (2008) 1004-1017. DOI: 10.1111/j.1472-4642.2008.00514.x

= M. GALÁNTHA: Beszámoló a sándorfalva-eperjesi ásatás eredményeiről (Report for results of excavation at Sándorfalva - Eperjes). MKCsM 1981, 17-23.

= E. GÁL: Animal remains from the Multi-period site of Hajdúnánás-Fürjhalom-dülö. I.: Sarmatian finds. ActaArchHung 61 (2010) 207-260.

= P. GREGUSS: A közép-európai lomblevelő fák és cserjék meghatározása szövettani alapon (Identificaton of Central European Trees and Shrubs on the Basis of Xylotomy). Országos Magyar Természettudományi Múzeum kiadványa, Budapest 1945.

= P. GREGuss: Xylotomy of the Living Conifers. Akadémia Kiadó, Budapest 1972.

= I. GYÖRFFY: Alföldi népélet (People Life on the Great Hungarian Plain). Gondolat Kiadó, Budapest 1983.

= F. GyULAI: Archeobotanika. A kultúrnövények története a Kárpát-medencében a régészeti növénytani vizsgálatok alapján (Archaeobotany. History of cultivated plants in the Carpathian Basin on the basis of archaeological-botanical analysis). Jószöveg Kézikönyvek Kiadó, Debrecen 2001.

= F. GYULAI: Kiskundorozsma-Nagyszék szarmata kori település növénymaradványai (Plant remains in a Sarmatian settlement in Kiskundorozsma-Nagyszék). In: Úton útfélen. Múzeumi kutatások az M5 autópálya nyomvonalában. Ed. Cs. Szalontai. Móra Ferenc Múzeum, Szeged 2003 141-148.

= F. GYUlAI: Archaeobotany in Hungary: Seed, Fruit, Food and Beverage Remains in the Carpathian Basin from the Neolithic to the Late Middle Ages. Archaeolingua 21. Archaeolingua Press, Budapest 2010 .

= F. GyUlaI: The history of broomcorn millet (Panicum miliaceum L.) in the Carpathian-Basin in the mirror of archaeobotanical remains. II.: From the Roman Age until the Late Medieval Age. Columella 1 (2014) 39-47.

= Gy. HALAVÁTs: Az Alföld Duna-Tisza közötti részének földtani viszonyai (The geological relationships of the Danube-Tisza Interfluve part of the Great Hungarian Plain). Magyar Királyi Földtani Intézet Évkönyve 11 (1895) 105-175.

= P. HAVAssy (ed.): Jazigok, roxolánok, alánok. Szarmaták az Alföldön (Jazigs, Roxolans, Alans. Sarmatians in the Great Hungarian Plain). Gyulai katalógusok 6. Erkel Ferenc Múzeum, Gyula 1998, Gyula.

= H. HoRUSITZKY: Löszterületek Magyarországon - Loess areas in Hungary. Földtani Közlöny 28 (1898) 29-36.

= H. HoRUsitzKY: A lösz (The loess). TtK 31/2 Suppl 50 (1899) 75-84.

= H. HoRUSITZKY: A diluviális mocsárlöszről (About diluvial infusion loess). FtK 33 (1903) 209-216.

$=$ H. HorUsitzKY: Előzetes jelentés a Nagy-Alföld diluviális mocsárlöszéről (Preliminary report for diluvial infusion loess from Great Hungarian Plain). FtK 35 (1905) 403-404.

= H. HoRUSITZKY: Újabb adatok a löszről és a diluviális faunáról (More data from loess and diluvial fauna). FtK 39 (1909) 135-143.

= H. HoRUSITZKY: A szegedi diluviális faunáról (Über die diluviale Fauna von Szeged). Földtani Közlöny 41 (1911) 249-254.

= E. IsTVÁNOVITs: Tiszavasvári-Városföldje, Jegyző-tag. - A settlement of the 5th century. JAMÉ 41 (1999) 173-254.

= E. IstvánOVITS-V. KulcsáR: From the Crimea to Scandinavia via the Great Hungarian Plain: Traces of Germanic-Sarmatian contacts on the basis of finds of spherical pendants and of other phenomena. In: Inter Ambo Maria. Contacts between Scandinavia and Crimea in the Roman Period. Eds: I. Khrapunov, F. A. Stylegar. DOLYA Publishing House, Kristiansand-Simferopol 2011, 80-90.

= E. IstVÁNOviTS-V. KULCSÁR: ,,...aligha állhat nekik bármely csatarend ellent” : Egy elfelejtett nép, a szarmaták (Sarmatians: History and Archaeology of a Forgotten People). Jósa András Múzeum kiadványai 74. Monográfiák a Szegedi Tudományegyetem Régészeti Tanszékéről 5. Jósa András Múzeum-Szegedi Tudományegyetem Régészeti Tanszék, Nyíregyháza-Szeged 2018.

= J. IVERSEN-K. FÆGRI: Textbook of Pollen Analysis. Scandinavian University Books, Copenhagen 1964. - 2nd ed.

= K. ÍRÁs: A Magyar Királyság első térképi megjelenése 14. századi portolán térképeken (First representations of Hungarian Kingdomon 14th century portolan charts). FrK 137 (2013) 64-73.

= G. L. JACOBSON-R. H. W. BRADSHAW: The selection of sites for palaeovegetational studies. Quaternary Research 16 (1981) 80-96.

= S. JACOMET-A. KREUZ: Archäobotanik. Aufgaben, Methoden und Ergebnisse vegetations- und agrargeschichtlicher Forschung. Ulmer, Stuttgart, 1999

= Gy. JuHÁsz: A pannoniai (s.l.) formációk térképezése az Alföldön: elterjedés, fácies és üledékes környezet (Pannonian (s.1.) lithostratigraphic units in the Great Hungarian Plain: distribution, facies and sedimentary environment). FtK 122 (1992) 133-165. 
JUHÁSZ-MAGYAR 1992

KIESEWALTER 1888

KOUDELKA 1885

KovÁcs et al. 2007

KovÁcs et al. 2008

KovÁCS-VÁCZI 2007

KOZÁKOVÁ-POKORNÝ 2007

KŐRÖSI 2010

KÖHEGYI 1984

KREYBIG 1937

KULCSÁR-VÖRÖS 1989

MAGYARI et al. 2010

MAGYARI et al. 2012

MAGYARI et al. 2014

MAROSI-SOMOGYI 1990

MASEK 2012

MASEK 2014

Matolcsi 1970

MENDÖL 1929

MENDÖL 1981

MinÁLTZ 1953
= Gy. JuHÁsZ-I. MAGYAR: A pannóniai (s.1.) litofáciesek és molluszka-biofáciesek jellemzése és korrelációja az Alföldön (Review and correlation of the Late Neogene (Pannonian s.1.) lithofacies and molluscbiofacies in the Great Plain, eastern Hungary). FtK 122 (1992) 167-194.

= L. KIESEWALTER: Skelettmessungen am Pferde. [Diss.] Leipzig 1888.

= F. KoudELKA: Das Verhältniss der Ossa longa zur Skeletthöhe bei den Säugertieren; Verhandl. d. Naturforsch. Ver. Brünn 24 (1885) 127-153.

= K. Kovács-K. SebőK-G. Szabó-G. VÁczi: Rákóczifalva, Bagi-föld (8/a sz. lh.). In: Régészeti kutatások Magyarországon 2006 (Archaeological Investigations in Hungary 2006). Ed.: J. Kisfaludi. Magyar Nemzeti Múzeum, Budapest 2007, 261-262.

= K. KovÁcs-K. SEbőK-G. SzABÓ-G. VÁczi: Rákóczifalva, Bagi-föld (8/a sz. lh.). In: Régészeti kutatások Magyarországon 2007 (Archaeological Investigations in Hungary 2007). Ed.: J. Kisfaludi. Magyar Nemzeti Múzeum, Budapest 2008, 266-267.

= K. KovÁcs-G. VÁczi: Rákóczifalva, Bagi-föld (8/a sz. lh.). In: Régészeti kutatások Magyarországon 2007 (Archaeological Investigations in Hungary 2007). Ed.: J. Kisfaludi. Magyar Nemzeti Múzeum, Budapest 2008, 261.

$=$ R. KozÁková-P. Pokorný: Dynamics of the biotopes at the edge of a medieval town: Pollen analysis of Vltava river sediments in Prague, Czech Republic. Preslia 79 (2007) 259-281.

= A. KőRösI: Szarmata és avarkori csonteszközök Felgyö-Kettőshalmon (Typology of the worked bone implements from Felgyő-Kettőshalmi dűlő). In: Csont és bőr. Az állati eredetű nyersanyagok feldolgozásának története, régészete és néprajza (Bone and Leather. History, archaeology and ethnography of crafts utilizing raw materials from animals). Eds: J. Gömöri, A. Körösi. Line Designe Kiadó, Budapest 2010, 99-115.

= M. KÖHEGYI: Kora szarmata aranyleletes női sírok az Alföldön (Frühsarmatische Frauengraber mit Goldfunden in der Grossen Ungarischen Tiefebene). DME 63 (1982) [1984] 267-355.

= L. KReYBIG: A M. Kir. Földtani Intézet talajfelvételi, vizsgálati és térképezési módszere (Die Methode der Boden-Kartierungin der Kgl. Ung. GeologischenAnstalt), M. Királyi Földtani Intézet Évkönyve 31 (1937) 147-244.

= V. KULCSÁR - I. VÖRÖS: Szarmata telep Lajosmizse határában (Sarmatian settlement on the outskirts of the Lajozsmizse). Cumania 11 (1989) 67-93.

= E. K. Magyari-J. C. Chapman-D. G. Passmore-J. R. M. Allen-J. P. Huntley-B. Huntley: Holocene persistence of wooded steppe in the Great Hungarian Plain. Journal of Biogeography 37 (2010) 915-935.

= E. Magyari-J. C. Chapman-A. S. FAirbairn-M. Francis-M. DE Guzman: Neolithic human impact on the landscapes of North-East Hungary inferred from pollen and settlement records. Vegetation History and Archaeobotany 21 (2012) 279-302.

= E. Magyari-P. Kunes-G. Jakab-P. SüMegi-B. PelánkovÁ-F. Schabitz-M. Braun-M. Chytry: Late Pleniglacial vegetation in eastern-central Europe: are there modern analogues in Siberia? Quaternary Science Reviews 95 (2014) 60-79.

= S. Marosi-S. SomogYI: Magyarország kistájainak katasztere I-II (Inventory of Microregions in Hungary I-II). MTA Földrajztudományi Kutatóintézet, Budapest 1990.

= Zs. MASEK: Kora népvándorlás kori települések kutatása Rákóczifalva-Bagi-földek 5-8-8A. lelőhelyek területén (Settlement surveys from the Early Migration Period at RákóczifalvaBagiföldek/Sites 5-8-8A/). In: Hadak útján. A Népvándorláskor Fiatal Kutatóinak XX. Összejövetelének konferenciakötete. Budapest-Szigethalom, 2010. október 28-30. Ed.: Zs. Petkes. Magyar Nemzeti Múzeum kiadványa, Budapest 2012, 43-59.

= Zs. MASEK: Száz gepida ház - a rákóczifalvi gepida település szerkezete („Hundred Gepid dwellings" - The Structure of the Gepid Settlementat Rákóczifalva). In: Hadak Útján. A Népvándorláskor Fiatal Kutatóinak XXIV. Összejövetelének konferenciakötete, Esztergom, 2014. november 4-6. Eds: A. Türk. Cs. Balogh, B. Major. Studia ad archaeologiam Pazmaniensia. A PPKE BTK Régészeti Tanszékének kiadványai 3/1 = MTA BTK Magyar Ôstörténeti Témacsoport kiadványai 3/1. Archaeolingua, Budapest-Esztergom, 2015, 407-445.

= J. MATOLCSI: Historische Erforschung der Körpergrösse des Rindes auf Grund von ungarischen Knochenmaterial. Zeitschrift für Tierzüchtung und Züchtungsbiologie 87/2 (1970) 89-137.

$=\mathrm{T}$. MENDöL: Egy alföldi óriásfalu életének története (The life history of a giant village from Great Hungarian Plain). Ifjúság és Élet 4 (1929) Nos 12, 18, 19.

$=$ T. MEndöL: Szarvas földrajza (Geography of Szarvas Town). Debrecen 1928. - Reprinted in the series: Bibliotheca Békésensis 23. Rózsa Ferenc Gimnázium, Békéscsaba 1981.

= I. MinÁltz: Az Észak-Alföld keleti részének földtani térképezése (Leve geologique de la partie orientale de L'Alföld septentrional). MÁFIJ 1951 (1953) 61-68. 
MOLNÁR 1965

MOORE et al. 1991

NAGY 1999

NANDRIS 1970

NANDRIS 1972

NÁFRÁDI-SÜMEGI 2013

NÁFRÁDI-SÜMEGI 2015

NoBIS 1954

PETő et al. 2017

PÉCSI 1993

PRENTICE 1985

PRENTICE et al. 1996

PUNT et al. 1995

PUNT et al. 2007

RAPAICS 1918

REILLE 1992

REILLE 1995

REILLE 1998

RÓNAI 1972

RÓNAI 1985

SCHOCH et al. 2004

SCHWEINGRUBER 1990

SHERRATT 1982

SHERRATT 1983

SOEPBOER et al 2007
= B. MolnÁR: Changes in area and directions of stream erosion in the eastern part of the Hungarian Basin (Great Plain) during the Pliocene and Pleistocene. Acta Minerologica et Petrographica Szegediensis 17 (1965) 39-52.

= P. D. Moore-J. A. WebB-M. E. Collinson: Pollen Analysis. Blackwell Scientific, Oxford 1991.

= M. NAGY: A gepida királyság (454-567). In: A gepidák - Kora középkori germán királyság az Alföldön (The Gepids - Early Medieval German Kingdom on the Great Hungarian Plain). Ed.: P. Havassy. Gyulai katalógusok 7. Erkel Ferenc Múzeum, Gyula 1999, 29-38.

= J. NANDRIS: Groundwater as a factor in the first temperate Neolithic settlement of the Körös Region. ZNM 6 (1970) 59-72.

$=\mathrm{J}$. NANDRIS: Relation between the Mesolithic, the First Temperate Neolithic and the Bandkeramik: The nature of the problem. Alba Regia 12 (1972) 61-70.

= K. NÁFRÁDI-P. SÜMEGI: Régészeti lelöhelyek szenült faanyagának határozása és értékelése a geoarcheológiai kutatásban (Identification and valuation of charcoal remains from archaeological sites in the geoarchaeological research). In: Geoszférák 2012. Eds: J. Unger, E. Pál-Molnár. GeoLitera Kiadó, Szeged 2013, 87-114.

= K. NÁFRÁDI-P. SÜMEGI: Régészeti és paleoökológiai lelöhelyekről származó szenült famaradványok vizsgálata és értékelése (Identification and valuation of charcoal remains from archaeological and palaeoecological sites). In: Komplex archeobotanika. Eds: T. Töröcsik, K. Náfrádi, P. Sümegi. GeoLitera, Szeged 2015, 117-129.

$=$ G. NobIS: Zur Kenntnis der ur- und frühgeschichtlichen Rinder Nord- und Mitteldeutschlands. Zeitschrift für Tierzüchtung und Züchtungsbiologie 63 (1954) 155-194.

= Á. PETő-Á. KenÉZ-Z. TóTH: Régészeti növénytani adatok a szarmaták mezőgazdaság- és gazdaságtörténeti kutatásához Hatvan-Baj-puszta és Apc-Farkas-major lelőhelyek alapján (Archaeobotanical data on the economy of the Sarmatians: the case study of Hatvan-Baj-puszta and Apc-Farkas-major, Heves County, Hungary). Archaeometriai Mühely 14/2 (2017) 117-128.

= M. PÉCSI: Negyedkor és löszkutatás [Quaternary and Loess Research.]. Akadémiai Kiadó, Budapest 1993.

= I. C. PRENTICE: Pollen representation, source area, and basin size: toward an unified theory of pollen analysis. Quaternary Research 23 (1985) 76-86.

= I. C. Prentice-J. Guiot-B. Huntley-D. Jolly-R. Cheddadi: Reconstructing biomes from palaeoecological data: a general method and its application to European pollen data at 0 and $6 \mathrm{ka}$. Climate Dynamics 12 (1996) 185-194.

= W. Punt-S. Blackmore-P. P. Hoen-P. J. Stafford: The Northwest European Pollen Flora. I-VII. Elsevier, Amsterdam 1976-1995.

= W. Punt-P. P. HoEn-S. BACKMORE-S. NiLSSON-A. Le ThOMAs: Glossary of pollen and spore terminology. Review of Palaeobotany and Palynology 143 (2007) 1-81.

= R. RAPAICS: Az Alföld növényföldrajzi jelleme I-II. (Phytogeographical character of the Great Hungarian Plain I-II.). Erdészeti Kísérletek 20 (1918) 1-97, 183-247.

= M. ReILlE: Pollen et spores d'Europe et d'Afrique du nord. Laboratoirede Botanique Historique et Palynologie, Marseille 1992.

$=$ M. ReILle: Pollen et Ssores d'Europe et d'Afrique du nord. Suppl. 1. Laboratoire de Botanique Historique et Palynologie, Marseille 1995.

= M. ReILlE: Pollen et spores d'Europe et d'Afrique du nord. Supplement 2. Laboratoire de Botanique Historique et Palynologie, Marseille 1998.

= A. RóNAI: Negyedkori üledékképződés és éghajlattörténet az Alföld medencéjében (Quartärsedimentation und Klimageschichteim Becken der Ungarischen Tiefebene (Alföld). MÁFIÉ 56. Müszaki Kiadó, Budapest 1972.

= A. RóNAI: Az Alföld negyedidőszaki földtana (The Quaternary of the Great Hungarian Plain). Geologica Hungarica 21. Institutum Geologicum Hungaricum, Budapest 1985.

= W. Schoch-I. Heller-F. H. Schweingruber-F. Kienast: Wood Anatomy of Central European Species. 2004. Online version: www.woodanatomy.ch

= F. H. SchweingRuber: Mikroskopische Holzanatomie. Birmensdorf, Eidgenössiche Forschungsanstalt für Wald, Schnee und Landchaft. Eidgenössische Anstalt für das Forstliche Versuchswesen, Birmensdorf 1990. - 3.Aufl.

= A. ShERRATt: The development of Neolithic and Copper Age settlement in the Great Hungarian Plain. 1.: The regional setting. OJA 1/3 (1982) 287-316.

= A. Sherratt: The development of Neolithic and Copper Age settlement in the Great Hungarian Plain. 2.: Site survey and settlement dynamics. OJA 2/1 (1983) 13-41.

= W. Soepboer-S. Sugita-A. F. Lotter-J. F. N. van Leeuwen-W. O. van der KnaAP: Pollen productivity estimates for quantitative reconstruction of vegetation cover on the Swiss Plateau. The Holocene 17 (2007) 65-77. 
STEGENA 1981

SUGÁR 1989

SugITA 1994

SÜMEGHY 1944

SÜMEGHY 1953

SÜMEGI 1989

SÜMEGI 1995

SÜMEGI 1996

SÜMEGI 2001

SÜMEGI 2002

SÜMEGI 2003

SÜMEGI 2004

SÜMEGI 2005

SÜMEGI 2011

SÜMEGI 2012

SÜMEGI 2013

SÜMEGI 2016

SÜMEGI-MOLNÁR 2007

SüMEGI et al. 1999

SÜMEGI et al. 2005

SÜMEGI et al. 2012
= L. STEGENA: Térképtörténet (Map Story). Tankönyvkiadó, Budapest 1981.

= I. SugÁR: A Közép-Tiszavidék két kéziratos térképe (Two Manuscript Maps for Middle Tisza Region). Tiszai téka 1. Dobó István Vármúzeum, Eger 1989.

$=$ S. SUGITA: Pollen representation of vegetation in Quaternary sediments: theory and method in patchy vegetation. Journal of Ecology 82 (1994) 881-897.

= J. SüMEGHY: A Tiszántúl (Transtiszaregion). Magyar tájak földtani leírása 6. M. Kir. Földtani Intézet, Budapest 1944.

= J. SÜMEGHY: Medencéink pliocén és pleisztocén rétegtani kérdései (Les problèmes stratigraphiques du Pliocène et du Pleistocène des nos bassins). MÁFIJ 1951 (1953) 83-107.

= P. SÜMEGI: Hajdúság felső-pleisztocén fejlődéstörténete finomrétegtani (üledékföldtani, őslénytani, geokémiai) vizsgálatok alapján [Upper Pleistocene evaluation of Hajdúság Region based on finestratigraphical (sedimentological, paleontological, geochemical) analyses]. [Dr. Univ. Thesis, manuscript] Debrecen 1989.

= P. SÜMEGI: Az utolsó 30.000 év változásainak rekonstrukciója őslénytani adatok alapján a Kárpátmedence centrális részén (Reconstruction of the changes of the last 30,000 years based on paleontological data in the central part of the Carpathian Basin). In: „Berényi Dénes professzor születésének 95. évfordulója” tiszteletére rendezett tudományos emlékülés előadásai. MTA Debreceni Területi Bizottsága-Meteorológiai Munkabizottság-KLTE Meteorológiai Tanszéke, Debrecen 1995, 244-258.

= P. SüMEGI: Az ÉK-magyarországi löszterületek összehasonlitó őskörnyezeti és sztratigráfiai értékelése. [Comparative paleoecological and startigraphical valuation of the NE Hungarian loess areas] [PhD diss., manuscript]. Debrecen-Budapest 1996.

= P. SÜMEGI: A negyedidőszak földtanának és őskörnyezettanának alapjai (Bases of the Quaternary geology and palaeoecology). JATEPress, Szeged 2001.

$=$ P. SÜMEGI: Régészeti geológia és történeti ökológia alapjai (Bases of the Geoarchaeology and Historical Ecology). JATEPress, Szeged 2002.

$=$ P. SüMEGI: Early Neolithic man and riparian environment in the Carpathian Basin. In: Morgenrot der Kulturen. Frühe Etappen der Menschheitsgeschichte in Mittel- und Südosteuropa. Festschrift für Nándor Kalicz zum 75. Geburtstag. Hrsg.: E. Jerem, P. Raczky. Archaeolingua 15. Archaeolingua, Budapest 2003, 53-60.

= P. SüMEGI: Findings of geoarcheological and environmental historical investigations at the Körös site of Tiszapüspöki-Karancspart Háromága. Antaeus 27 (2004) 307-342.

= P. SÜMEGI: Loess and Upper Paleolithic Environment in Hungary. Aurea Kiadó, Nagykovácsi 2005.

= P. SÜMEGI P. Sümegi: A link between regions - The role of the Danube in the life of European communities. In: Ten Thousand Years along the Middle Danube. Life and Early Communities from Prehistory to History. Eds: Gy. Kovács, G. Kulcsár. VAH 26. Archaeolingua, Budapest 2011, 9-44.

= P. SüMEGI: The environmental background of the Körös culture. In: The First Neolithic Sites in Central/South-East European Transect. III.: The Körös Culture in Eastern Hungary. Eds: A. Anders, Zs. Siklósi. BAR IntSer 23349. Archeopress, Oxford 2012, 39-49.

$=$ P. SÜMEGI: Régészeti geológia és történeti ökológia alapjai (Bases of Geoarchaeology and Historical Ecology). JATEPress, Szeged 2013. - New ed.

= P. SüMEGI: Ökorégiók találkozási pontja, a Kárpát-medence környezettörténete (A meeting point of the ecoregions - the environmental history of the Carpathian Basin). Természet Világa 147 (2016) Spec.No 1, 7-11.

= P. SüMEgI-S. Molnár: The Kiritó meander: sediments and the question of flooding. In: The Early Neolithic on the Great Hungarian Plain. Investigations of the Körös culture site of Ecsegfalva 23, Co. Békés. Ed.: A. W. R. Whittle. VAH 21. Archaeological Institute of the Hungarian Academy of Sciences, Budapest 2007, 67-82.

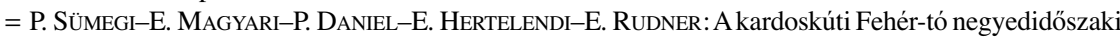
fejlődéstörténetének rekonstrukciója (A reconstruction of the Quaternary geohistory of Fehér lake at Kardoskut). FtK 129 (1999) 479-519.

= P. SüMegi-B. CsöKmeI-G. Persaits: The evolution of Polgár Island. A loess covered lag surface and its influences on the subsistence of settling human cultural groups. In: Environmental Historical Studies from the Late Tertiary and Quaternary of Hungary. Eds: L. Hum, S. Gulyás, P. Sümegi. Department of Geology and Paleontology, University of Szeged, Szeged 2005, 141-163.

= P. SüMEgI-G. Persaits-S. Gulyás: Woodland-Grassland ecotonal shifts in environmental mosaics: Lessons learnt from the environmental history of the Carpathian Basin (Central Europe) during the Holocene and the Last Ice Age based on investigation of paleobotanical and mollusk remains. In: Ecotones Between Forest and Grassland. Ed.: R. W. Myster Springer Press, New York 2012, 17-57. 
SÜMEGI et al. 2013a

SÜMEGI et al. 2013b

SÜMEGI et al. 2015

SÜMEGI et al. 2018

SZABÓ-VÖRÖS 1979

SZELEPCSÉNYI et al. 2014

SZELEPCSÉNYI et al. 2018

TEICHERT 1969

TEICHERT 1975

TIMÁR et al. 2005

TIMÁR et al. 2006

В. То́тн 1999

B. То́тн 2003

B. То́тн 2004

B. Tóth 2006

TóTH 2004

TÖRŐCSIK-SÜMEGI 2016

TÖRŐCSIK-SÜMEGI 2018

TÖRŐCSIK et al. 2015

TÖRŐCSIK et al. 2019

TöRÖK 1996
= P. SÜMEgI-E. MAGYARI-P. DÁNIEL-M. MolnÁR-T. TÖRŐCSIK: 28,000-year record of environmental change in SE Hungary: terrestrial response to Dansgaard-Oeshger cycles and Heinrich-events. Quaternary International 278 (2013) 34-50.

= P. SÜMEGI-G. SzILÁGYI-S. GulYÁs-G. JAKAB-A. MolnáR: The Late Quaternary Paleoecology and environmental history of the Hortobágy, an unique mosaic alkaline steppe from the heart of the Carpathian Basin, Central Europe. In: Steppe Ecosystems Biological Diversity, Management and Restoration. Eds: M. B. M. Prieto, T. B. Diaz. Nova Publishers, New York 2013, 165-194.

= P. SÜMEGI-K. NÁFRÁdI-D. MolNÁR-Sz. SÁviA: Results of paleoecological studies in the loess region of Szeged-Öthalom (SE Hungary). Quaternary International 372 (2015) 66-78.

= P. Sümegi-D. Molnár-S. Gulyás-K. NÁfrádi-B. P. Sümegi-T. Töröcsik-G. PersaitsM. MolnÁR-J. VAndenberghe-L. Zhou: High-resolution proxy record of the environmental response to climatic variations during transition MIS3/MIS2 and MIS2 in Central Europe: the loess-palaeosol sequence of Katymár brickyard (Hungary). Quaternary International, 2018, in press.

= J. SzAвÓ-I. VöRös: Gepida lelöhelyek Battonya határában. (Gepidische Fundorten in der Gemarkung von Battonya.) ArchÉrt 106 (1979) 218-230.

$=$ Z. SZELEPCSÉNYI-H. BREUER-P. SÜMEGI: The climate of Carpathian Region in the 20th century based on the original and modified Holdridge life zone system. Central European Journal of Geosciences 6 (2014) 293-307.

= Z. SzelepcsÉnYI-H. Breuer-A. Kis-R. PongrÁCZ-P. SÜMEgI: Assessment of projected climate change in the Carpathian Region using the Holdridge life zone system. Theoretical and Applied Climatology 31 (2018) 1-18.

= M. TEICHERT: Osteologische Unterschungen zur Berechnung der Widerristhöhe bei vor- und frühgeshcichtlichen Schweinen. Kühn Archiv 83/3 (1969) 237-292.

= M. TEICHERT: Osteologische Untersuchungen zur Berechnung der Widerristhöhe bei Schafen. In: Archaezoological Studies. Ed.: A. T. Clason. North Holland Publ. and American Elsevier, Amsterdam-New York 1975, 51-69.

= G. TIMÁR-P. SüMEGI-F. HorvÁth: Late Quaternary dynamics of Tisza River: Evidence of climatic and tectonic controlls. Tectonophysics 410 (2005) 97-110.

= G. Timár-G. MolnáR-B. SzÉKEly-S. BisZAK-J. VARGA-A. Jankó: Digitized Maps of the Habsburg Empire - The map sheets of the Second Military Survey and their georeferenced version. Arcanum Kiadó, Budapest 2006.

= Á. B. Tóth: „Gothiskandza”-tól a Tisza vidékig. A gepidák eredete, vándorlása, korai régészeti emlékanyaga (From „Gothiskandza” to Tisza Region. Gepids origin, migration and early archaeological relics). In: A gepidák - Kora középkori germán királyság az Alföldön. Ed.: P. Havassy. Gyulai katalógusok 7. Erkel Ferenc Múzeum, Gyula 1999, 11-28.

= Á. B. Tо́тн: Gepidák. In: Magyar régészet az ezredfordulón (Hungarian Archaeology at the Millennium). Ed: Zs. Visy. Nemzeti Kulturális Örökség Minisztériumának Kiadványa, Budapest 2003, 294-298.

= Á. B. Tóтн: Gepids. In: Hungarian Archaeology at the Millennium. Ed: Zs. Visy. Nemzeti Kulturális Örökség Minisztériumának Kiadványa, Budapest 2004, 294-298.

= Á. B. TóTH: Gepidische Siedlung im Theissgebiet. MGAH 4. Magyar Nemzeti Múzeum, Budapest 2006.

= E. TóTH: Római utak Pannoniában (Roman imperial roads in Pannonia province). Ókor 1 (2004) 43-48.

$=$ T. TÖRŐCSIK-P. SÜMEGI: Ember, környezet és növényzet kapcsolata a Kárpát-medencében a jégkor végétől napjainkig (Contact among man, environment and vegetation in the Carpathian Basin from the terminalphase of the Ice Age until today). Természet Világa, 147 (2016) Spec.N. 1, 49-57.

$=\mathrm{T}$. TÖRŐCSIK-P. SÜMEGI: Pollen alapú növénytermesztési rekonstrukció a Kárpát-medencében a magyar honfoglalás korában (Pollen-based reconstruction of the plant cultivation in the Carpathian Basin during Hungarian Conquest) In: Magyarok a Kárpát-medencében 3.: Tudományos Nemzetközi Konferencia, Ópusztaszer. Ed.: G. Szónokyné Ancsin. Közép-európai monográfiák 17. Egyesület Közép-Európa Kutatására, Szeged 2018, 17-35.

= T. TÖRŐCSIK-K. NÁFRÁDI-P. SÜMEGI: Komplex archeobotanika 8 (Complex Archaeobotany 8). Geolitera Kiadó, Szeged 2015.

= T. TÖRŐCSIK-S. GulYÁS-B. SÜMEGI-P. SÜMEGI-D. MolNÁR-R. BENYÓ-KorCSMÁros: Environmental History of the Csorna Plain (Western Danube Plain, Nw Hungary) from the Late Glacial to the Late Holocene as seen from data of multiproxy geoarchaeological investigations. Studia Quaternaria 36 (2019) 19-43.

= Zs. TöRÖK: A Lázár-térkép és a modern európai térképészet (Lázár's map and modern European cartography). Cartographica Hungarica 5 (1996) 44-45. 
Troels-SMITH 1955

TUGYA 2010

TugYA-RÓZSA 2012

TugYA-LiChTENSTEIN 2014

VADAY 1989

VADAY-VÖRÖS 1980

VITT 1952

VÖRÖS 1998

VÖRÖS 2005

VÖRÖs 2012

WALTER-LIETH 1960
= J. TROELS-Smith: Karakterisering af lose jordater (Characterisation of Unconsolidated Sediments). Danmarks Geologiske Undersogelse, IV. Raekke 3/10 Reitzels Forlag, København 1955.

= B. TugYA: A kutyahús fogyasztásának archaeozoológiai bizonyítékai - The archaeozoological evidences of dog meat consumption. In: Évkönyv és jelentés a KÖSZ 2008. évi feltárásairól. Ed.: J. Kvassay. Kulturális Örökségvédelmi Szakszolgálat, Budapest 2010, 99-106.

= B. TugYA-Z. RózsA: A szaru, mint nyersanyag felhasználása Orosháza-Községporta-Szűcs-tanya szarmata lelőhelyen. Régészeti, archaeozoológiai, néprajzi vonatkozások (Use of horn as a raw material from the Sarmatian excavation site of Szücs Tanya in Községporta, Orosháza. Archaeological, archaeozoological and ethnographical references). In: Környezet-ember-kultúra: Az alkalmazott természettudományok és a régészet párbeszéde. Magyar Nemzeti Múzeum Nemzeti Örökségvédelmi Központ 2010. október 6-8-án megrendezett konferenciájának tanulmánykötete. Eds: A. Kreiter et al. Magyar Nemzeti Múzeum, Budapest 2012, 225-230.

= B. TugYa-L. Lichtenstein: Dunavecse-Ugordáció I. lelőhely II-V. századi objektumainak archeozoológiai értékelése (Archaeozoological analysis of the $2^{\text {nd }}-5^{\text {th }}$ century features, Dunavecse-Ugordáció site I). In: A Barbaricum ösvényein. A 2005-ben Kecskeméten tartott tudományos konferencia előadásai. Eds: Á. Somogyvári, Gy. V. Székely. Archaeologica Cumanica 1. Katona József Múzeum, Kecskemét 2011 (2014) 145-160.

= A. H. VADAY: Die sarmatischen Denkmaler des Komitats Szolnok. Ein Beitrag zur Archaologie und Geschichte des sarmatischen Barbaricums. Antaeus 17-18. Archaeological Institute of the Hungarian Academy of Sciences, Budapest 1989.

= A. VADAY-I. VöRÖs: Szarmata település Kunszentmártonban (Sarmatian settlement at Kunszentmárton). SzMMÉ 1980, 117-139.

= O. V. VITT: Losadi pazirykskih kurganov [Horses of the paziriki kurgans]. SA 16 (1952) 51-69.

= G. VöRös: Településszerkezet és életmód, az alföldi szarmaták falvaiban (The structure of settlement, way of life in the Sarmatian villages on the Great Hungarian Plain). In: Havassy 1998, 49-65.

= I. VöRÖs: Állatcsontleletek Vámospércs határából (Animal bones finds from environs of Vámospércs). A DMÉ 2004 (2005) 71-81.

= I. VÖRÖS: Kántorjánosi-Homoki-dülő állatcsont maradványai (Animal bone remains of KántorjánosiHomoki-dűlő site). In: Ante viam stratam. A Magyar Nemzeti Múzeum megelőző feltárásai Kántorjánosi és Pócspetri határában, az M3 autópálya Nyírségi nyomvonalán. Eds: Á. Szabó, Zs. Masek. Magyar Nemzeti Múzeum, Budapest 2012, 487-518.

= H. WALTER-H. Lieth: Klimadiagramm Weltatlas. Fischer Verlag, Jena 1960.

Open Access. This is an open-access article distributed under the terms of the Creative Commons Attribution 4.0 International License (https:// creativecommons.org/licenses/by/4.0), which permits unrestricted use, distribution, and reproduction in any medium, provided the original author and source are credited, a link to the CC License is provided, and changes - if any - are indicated. (SID_1) 